Author: Sean Curran, Trinity College, Cambridge (spc40@cam.ac.uk)

Peer-reviewed journal article: 'Hockets Broken and Integrated in Early Mensural Theory and an Early Motet'.

Journal: Early Music History, volume 36 (October 2017)

Author's revised manuscript: accepted 4 May 2017

\title{
Abstract
}

Notwithstanding recent discoveries of big, textless hockets from the late thirteenth century, there remains a pervasive uncertainty as to how hockets should be defined and identified on the small scale at which they characteristically manifest in thirteenth-century motets. Revisiting the mensural theorists up to Franco of Cologne this article finds that only with Franco must hockets be multi-voice phenomena: earlier texts define the hocket at the level of a single perfection, and as it manifests in the breaking of a single performing voice. Under a revised definition, 138 motet texts that use hockets are identified in the Ars Antiqua repertory. A second look at the $\mathrm{St}$ Emmeram Anonymous (who builds on Lambertus more than he lets on) finds that he acknowledges but departs from the consensus that the hocket is sonically fragmented, also hearing it as a promise of the co-ordination achievable when musical time is measured. For him, the hocket had a dual character, its sonic fragmentation contrived through integrated planning. But hearing hockets integratively is difficult, and requires an effort of will that (for St Emmeram) has moral stakes.

The final sections of the article analyse the musicopoetic games of the motet Dame de valour (71) / Dame vostre douz regart (72) / MANERE (M5), finding that (like St Emmeram), the piece self-consciously highlights the difficulty and worth of close listening (a theme inspired by its tenor's scriptural source). Through the cloud of citational references that cut across the parts, forged by materials drawn from the motet's refrains, we are invited to hear with understanding the formal patterns the same materials build in each individual voice, and a reciprocity at which those patterns arrive. The hocket depicts a vocal failure caused by heartbreak just as the triplum stages the composition of a new song out of the experience of love: the hocket marks a complementarity of breaking and integration, and of a formal sort. Several decades before St Emmeram would reflect on the hocket's dual character theoretically, the motet's composer knew it as a creative resource, and turned to it as a means of posing artfully some questions about the audibility of form that preoccupy modern scholarship. The motetus's narrator seems to understand what is going on: falling silent in his hocket, he receives a message that has transformative effects on him, whose implications I conclude by pondering. Across eight centuries, these voices from the thirteenth century might remind us that ethical debates about correct listening are much older than current disciplinary concerns. But recognizing the debate's longevity does not force us to agree with old positions. 
Sean Curran, 'Hockets Broken and Integrated in Early Mensural Theory and an Early Motet', Early Music History vol. 36 (2017); author's revised manuscript, accepted 4 May 2017.

\section{Hockets Broken and Integrated in Early Mensural Theory and an Early Motet ${ }^{1}$}

Looks can kill — something the narrator of the motetus Dame vostre douz regart (72) knows all too well. ${ }^{2}$ (Appendix 1 presents the texts and translations of the

${ }^{1}$ Grateful thanks to all who commented on this work, live or by correspondence, and particularly Sam Barrett, Susan Boynton, Bill Burgwinkle, Ardis Butterfield, Mary Carruthers, Suzannah Clark, Karen Desmond, Elizabeth Eva Leach, Susan Rankin, Owen Rees, and Jeremy Yudkin. Thanks, too, to anonymous reviewers who sharpened the argument. Special thanks to Nicolas Bell, Margaret Bent, and Teresa Webber, for innumerable forms of intellectual support. The most profound debt of gratitude is the one I owe to Emma Dillon.

The following abbreviations are used:

Ba Bamberg, Staatsbibliothek, Lit. 115 (olim Ed.IV.6).

Cl Paris, Bibliothèque nationale de France, nouvelles acquisitions françaises, 13521 (the 'La Clayette' Manuscript).

LoV London, British Library, Cotton Vespasian A XVIII.

Ma Madrid, Biblioteca nacional de España, 20486.

Mo Montpellier, Bibliothèque Interuniversitaire, Section Médecine, H 196 (Montpellier Codex).

MuA Munich, Bayerische Staatsbibliothek, mus. 4775 (gallo-rom. 42).

N Paris, Bibliothèque nationale de France, français 12615 (Chansonnier de Noailles).

R Paris, Bibliothèque nationale de France, français 844 (Chansonnier du Roi).

Tu Turin, Biblioteca Reale, Vari 42.

W2 Wolfenbüttel, Herzog August Bibliothek, Cod. Guelf. 1099 Helmst. (Olim 1206).

${ }^{2}$ The full motet is Dame de valour (71) / Dame vostre douz regart (72) / MANERE (M5).

Numbers in parentheses refer to an items' position in the index by F. Gennrich, Bibliographie der ältesten französischen und lateinischen Motetten, (Summa Musicae Medii Aevi, 2; 
Sean Curran, 'Hockets Broken and Integrated in Early Mensural Theory and an Early Motet', Early Music History vol. 36 (2017); author's revised manuscript, accepted 4 May 2017.

motet's parts, and an edition of the piece. $\left.{ }^{3}\right)$ He has taken leave from the Lady he addresses, and the memory of her look causes symptoms that neatly introduce the subject of this article. The narrator is wound up to breaking point, and it tells in his melody. After verse 10 (b. 35), between the pair of rhyming words 'aler' and 'parler', the musical setting does something strange: it stops. The two syllables of each word describe a falling fifth, and are set with a single foot of Garlandia's second rhythmic mode, followed by a silence lasting for a long of three tempora. ${ }^{4}$ Demonstrating the condition he describes, the narrator literally cannot speak (and indeed, his sudden vocal immobility is fitting for one that 'cannot $g o$ ' to his lover either). ${ }^{5}$ The refrain makes the musicopoetic conceit retroactively clear: 'Li maus d'amer me debrise / Et la doulor que je sent': 'The pain of love is breaking me / And the suffering that I feel'. Debrisier means 'to break', 'to shatter', or 'to fracture'. ${ }^{6}$ The narrator is cracking up, and so is his voice.

Frankfurt, 1957), and H. van der Werf, Integrated Directory of Organa, Clausulae and Motets of the Thirteenth Century (Rochester, NY, 1989). On the topos of the lover's look in some fourteenth-century songs, see K. Desmond, 'Refusal, the Look of Love, and the Beastly Woman of Machaut's Balades 27 and 38', Early Music History, 32 (2013), pp. 71-118.

${ }^{3}$ From the witness in Mo, fols. $128^{\mathrm{v}}-130^{\mathrm{r}}$. I discuss the network of sources and related pieces below. All editions, transcriptions, and translations are my own unless otherwise noted.

${ }^{4}$ I identify rhythmic modes according to the Garlandian terminology that has become a scholarly standard. Theorists of the later thirteenth century - notably Lambertus and Franco construed and numbered rhythmic modes differently.

${ }^{5}$ My thanks to an anonymous reader for emphasising the implication of immobility, as well as of vocal failure.

${ }^{6}$ S.v. 'debrisier', Old French-English Dictionary, by A. Hindley, F. W. Langley and B. J. Levy (Cambridge, 2000), p. 181. 
Sean Curran, 'Hockets Broken and Integrated in Early Mensural Theory and an Early Motet', Early Music History vol. 36 (2017); author's revised manuscript, accepted 4 May 2017.

On what grounds can we call this moment a hocket? Certainly it lacks the grand scope of fourteenth-century motet-hockets like those recently discussed by Anna Zayaruznaya ${ }^{7}$ and Thomas Schmidt-Beste. ${ }^{8}$ Here presented as a single part, our passage cannot display pitch repetition between voices, or indeed voice-exchange features widespread in Parisian polyphony of the late twelfth century, foregrounded by the long melismatic hockets of the later thirteenth, and familiar from textbook and reference descriptions of hockets. ${ }^{9}$ Of the pitch-repetition sort, a good example is the famous In seculum hocket, given pride of place at the start of Montpellier's fifth

${ }^{7}$ Zayaruznaya, 'Hockets as Compositional and Scribal Practice in the Ars nova Motet-A Letter from Lady Music', The Journal of Musicology, 30 (2013), pp. 461-501; and A. Zayaruznaya, The Monstrous New Art: Divided Forms in the Late Medieval Motet (Music in Context; Cambridge, 2015).

${ }^{8}$ Schmidt-Beste, 'Singing the Hiccup — on Texting the Hocket', Early Music History, 32 (2013), pp. 225-275.

${ }^{9}$ Perhaps most influentially for students of the 1980s and 1990s, R. H. Hoppin, Medieval Music (The Norton Introduction to Music History; New York, 1978), p. 344: 'Medieval theorists defined hocket as a 'truncation' in which one voice sings while another is silent'. Ernest H. Sanders (in 'Hocket', Grove Music Online, $\leq$ http://www.oxfordmusiconline.com>, acc. 23 April 2016) offers a more encompassing definition: 'The medieval term for a contrapuntal technique of manipulating silence as a precise mensural value in the $13^{\text {th }}$ and $14^{\text {th }}$ centuries. It occurs in a single voice or, most commonly, in two or more voices, which deploy the dovetailing of sounds and silences by means of the staggered arrangement of rests'. Though the remainder of Sanders' article considers multi-voice hocket almost exclusively. 
Sean Curran, 'Hockets Broken and Integrated in Early Mensural Theory and an Early Motet', Early Music History vol. 36 (2017); author's revised manuscript, accepted 4 May 2017.

fascicle. ${ }^{10}$ (See Example 1.) From their opening unison, the upper two voices soon perform alternating pitch repetitions (bb. 4-5), or just alternations of different pitches (b. 6). Perhaps a little later, two further versions of the piece were added as items two and three of fascicle $1 .^{11}$ Both share a texted quadruplum, Ja n'amerai (211), but the former piece casts the whole edifice in the shorter, second rhythmic mode, ${ }^{12}$ the latter in the longer fifth ${ }^{13}$ - a kind of rhythmic transformation that seems to have become characteristic of hockets. ${ }^{14}$ To judge from the prominent position they gave these In

${ }^{10} \mathrm{Mo}$, fol. $111^{\mathrm{r}}$; also preserved in $\mathrm{Ba}$, fol. $63^{\mathrm{v}}$. For a list of sources and related pieces, see van der Werf, Integrated Directory, p. 31 (for the melismatic hockets) and p. 35 (for the hockets with associated texted voices).

${ }^{11}$ A broad consensus holds that fascicle 1 of Mo was (along with fascicle 7) a later addition to the manuscript's core, now fascicles 2-6 (probably of the 1270s); fascicle 8 was added later still. For discussion, see M. Everist, Polyphonic Music in Thirteenth-Century France: Aspects of Sources and Distribution (Outstanding Dissertations in Music from British Universities; New York, 1989), pp. 110-34. For an alternative perspective (holding that fascicles 1-7 were created together in the $1260 \mathrm{~s}$ or $70 \mathrm{~s}$; and that fascicle 8 may, among other possibilities, have been broadly contemporaneous with them), see M. E. Wolinski, 'The Compilation of the Montpellier Codex', Early Music History, 11 (1992), pp. 263-301.

${ }^{12}$ Mo, fols. $1^{\mathrm{v}}-3^{\mathrm{r}}$.

${ }^{13}$ Mo, fols. $2^{\mathrm{v}}-4^{\mathrm{r}}$. Another version survives, which shares three of the four voices of fascicle 1's versions, but omits their triplum, and supplies a French text for the duplum, to build a three-part motet: Ja n'amerai autre que cele (211) / Sire dieus (212) / IN SECULUM (M13), preserved in Mo, fols. $187^{\mathrm{v}}-189^{\mathrm{r}}$, and $\mathrm{Cl}$, fols. $387^{\mathrm{r}}-387^{\mathrm{v}}$.

${ }^{14}$ Another pair of melismatic hockets in Ba also share music set in long- and short-mode versions: an 'In seculum d'Amiens longum' is found on fols. $64^{\mathrm{r}}-64^{\mathrm{v}}$, followed on fol. $64^{\mathrm{v}}$ by its short-mode twin (whose incipit is simply 'In seculum'). 
Sean Curran, 'Hockets Broken and Integrated in Early Mensural Theory and an Early Motet', Early Music History vol. 36 (2017); author's revised manuscript, accepted 4 May 2017.

seculum pieces in the luxurious Montpellier Codex, contemporary musicians were proud of their big hockets. One might reasonably think a lovelorn singer's bleatings hardly compare.

\section{[EXAMPLE 1 NEAR HERE]}

Large hockets have done well in recent scholarship, especially thanks to new discoveries: the two MANERE hockets found by Barbara Haggh and identified by Mary E. Wolinski, ${ }^{15}$ and the Ave maria hoquetato discovered by Santiago Ruiz Torres and Juan Rubio Sadia, and reconstructed by David Catalunya. ${ }^{16}$ The MANERE pieces give us a new pair of modally transformed hockets, ${ }^{17}$ while the Ave Maria hoquetato probably furnishes us with another example of what the theorist Jacobus in his Speculum musicae calls the 'contraduplex' hocket. ${ }^{18}$ Both discoveries supply practical

${ }^{15}$ Wolinski and Haggh, 'Two $13^{\text {th }}$-Century Hockets on Manere Recovered', Early Music, 38 (2010), pp. 43-57. The discovered source is the front flyleaf of Dijon, Bibliothèque Municipale, MS 447.

${ }^{16}$ Ruiz Torres, 'Reconstructing the Past: The Documentary Context of the Sigüenza Ars Antiqua Fragment', Studi Musicali, nuova serie, 5 (2014), pp. 83-90; and D. Catalunya, 'Medieval Polyphony in the Cathedral of Sigüenza: A New Identification of a Musical Example Quoted in the Anonymous Treatise of St Emmeram (1279)', Studi Musicali, nuova serie, 5 (2014), pp. 41-82. The source is Sigüenza, Archivo de la Catedral, MS 83.

${ }^{17}$ See Wolinski and Haggh, 'Two 13th-Century Hockets', p. 44.

${ }^{18}$ So suggests Catalunya: see 'Medieval Polyphony in the Cathedral of Sigüenza', p. 57 n. 43. For the other example, see P. Jeffery, ‘A Four-Part “In Seculum” Hocket and a Mensural Sequence in an Unknown Fragment', Journal of the American Musicological Society, 37 (1984), pp. 1-48. For the theoretical references, see R. Bragard (ed.), Jacobi Leodiensis Speculum musicae, 7 vols (Corpus Scriptorum de Musica, 3; Rome, 1955-1973), vii, p. 24 and p. 89 . 
Sean Curran, 'Hockets Broken and Integrated in Early Mensural Theory and an Early Motet', Early Music History vol. 36 (2017); author's revised manuscript, accepted 4 May 2017.

sources for musical examples cited by the Anonymous of St Emmeram (writing in 1279), but long thought lost. ${ }^{19}$

However, though our knowledge of large, late hockets has been enriched greatly by these studies, we still have much looser purchase on hockets in early motets, composed perhaps before the device became a genre in its own right. In motets, hockets can be little, passing in an instant: the problem is catching them. We have long known they exist in older motets. Yvonne Rokseth pointed to four in the Old Corpus of Mo as long ago as $1939,{ }^{20}$ and editors have often observed passing hockets in critical commentaries. ${ }^{21}$ Echoing Rokseth, Finn Mathiassen emphasized the diminutive stature of hockets in early motets, going so far as to suggest that 'such cutting off of single notes and words, even syllables, may be considered a kind of

${ }^{19}$ De musica mensurata: The Anonymous of St. Emmeram, ed. and trans J. Yudkin (Music: Scholarship and Performance; Bloomington, 1990); the citation of Ave Maria hoquetato is found (with the incipit 'Amen') at p. 226 (Latin) and p. 227 (English translation). The two MANERE citations are at pp. 228/229.

${ }^{20}$ Rokseth, Polyphonies du XIII siècle: Le manuscrit H 196 de la Faculté de Médecine de Montpellier, 4 vols (Paris, 1935-39), iv, p. 83. The motets are nos. 39, 78, 134, and 137 of that edition.

${ }^{21}$ For instance, having edited the Latin contrafact of Dame vostre douce regart, Jesu Christi sedulus (73) from W2, Gordon A. Anderson writes: 'The hocket passage in the motetus... is an interesting use of this device, and comes at a point of climax both in the music and in the text of both voices. The tenor, too, reaches its point of climax at this section'. See The Latin Compositions in Fascicules VII and VIII of the Notre Dame Manuscript, Wolfenbüttel, Helmstadt 1099 (1206), 2 vols. (Musicological Studies, 24; Brooklyn, NY, 1968), ii, p. 299. Anderson does not elaborate; but I will argue that the hocket indeed marks an important moment in the motet's design. 
Sean Curran, 'Hockets Broken and Integrated in Early Mensural Theory and an Early Motet', Early Music History vol. 36 (2017); author's revised manuscript, accepted 4 May 2017.

hocket'. ${ }^{22}$ We will see that this was insightful. He found only three 'real' hockets, however, by which he meant 'the truncation of unaccented notes'. ${ }^{23}$ Rokseth noticed that her hockets figured the sobs and sighs of lovers, ${ }^{24}$ a position on hocketonomatopoeia echoed in the standard New Grove $e^{25}$ and $M G G^{26}$ articles, but held by their authors to be rare.

At least three attempts have been made to list hockets in early motets, but they have not yielded many pieces. Denis Harbinson found only five relevant motets in the

\footnotetext{
${ }^{22}$ Mathiassen, The Style of the Early Motet (c.1200-1250): An Investigation of the Old Corpus of the Montpellier Manuscript (Studier Og Publikationer Fra Musikvidenskabeligt Institut, Aarhus Universitet, 1; Copenhagen, 1966), p. 77 (emphasis mine).

${ }^{23}$ Ibid. The three motets, cited at p. 77 n. 83, are nos. 39, 73, and 137 in Rokseth, Polyphonies $d u X I I I^{e}$ siècle, vols. 2-3. Mathiassen put perfections 33-37 of our motet on the extreme end
} of a normal spectrum of motet-voice phrase lengths (The Style of the Early Motet, p. 75). There is no sign he considers the passage a hocket.

${ }^{24}$ Rokseth, Polyphonies du XIII siècle, iv, p. 226. Indeed, Rokseth finds hockets an exception to the general rule that 'expressive' relationships between music and textual image did not concern the composer of early motets: 'Nous serions déçus pourtant si nous pensions y trouver une correspondance expressive entre le sens des paroles et les images musicales. Aucune intention de ce genre ne paraît avoir occupé le compositeur. Tout au plus semble-t-il que le procédé du hoquet ait très tôt révélé son aptitude à traduire les soupirs, les sanglots'.

(Ibid.)

${ }^{25}$ Sanders, 'Hocket', Grove Music Online.

${ }^{26}$ K. Kügle, 'Hoquetus', Die Musik in Geschichte und Gegenwart, 2nd edn., ed. L Finscher, Sachteil, vol. 14 (Kassel and Stuttgart, 1996), cols. 355-61; at col. 356. 
Sean Curran, 'Hockets Broken and Integrated in Early Mensural Theory and an Early Motet', Early Music History vol. 36 (2017); author's revised manuscript, accepted 4 May 2017.

Old Corpus of Mo, and ours does not number among them; ${ }^{27}$ while Hans Tischler found nine among the early pieces he edited, and here our motet does feature. ${ }^{28}$ In a 2013 article, Thomas Schmidt-Beste compiled a list of texted hockets from the thirteenth through fifteenth centuries for a palaeographical study of texting practices. ${ }^{29}$ Given his interest in the scribal mechanics of matching words to hockets, he sensibly limited analysis to passages long enough to have presented scribes with problems; so his list excludes onomatopoetic hockets, ${ }^{30}$ hockets of less than 'two bars', ${ }^{31}$ and hockets in only one part, calling them (after the Anonymous of St

${ }^{27}$ D. Harbinson, 'The Hocket Motets in the Old Corpus of the Montpellier Manuscript', Musica Disciplina 25 (1971), pp. 99-112, at p. 99. The pieces are nos. 2, 3, 5, 73, and 137 in Rokseth, Polyphonies du XIII siècle, vol. 2.

${ }^{28} \mathrm{H}$. Tischler, The Style and Evolution of the Earliest Motets (to circa 1270), 4 vols. (Musicological Studies, 40; Ottawa, Ont., 1985), p. 93 n. 40; he lists nos. 14b, 47, 57, 129, 142, 145, 214, 234, 240 1 of The Earliest Motets (to circa 1270): A Complete Comparative Edition, ed. H. Tischler, 3 vols. (New Haven, and London, 1982). With one exception (no. 145, in which I find no hocket), all these pieces are also on my list; though Tischler's nos. 214,234 , and $240_{1}$ are from $\mathrm{Cl}$, and thus appear in the portion of my appendix dedicated to that manuscript, and compiled from Motets of the Manuscript La Clayette: Bibliothèque Nationale, Nouv. Acq. F. Fr. 13521, ed. G. A. Anderson (Corpus Mensurabilis Musicae, 68; Neuhausen-Stuttgart, 1975), in which they are nos. 10, 46, and 54, respectively. ${ }^{29}$ Schmidt-Beste, 'Singing the Hiccup', pp. 269-75.

${ }^{30}$ Ibid., p. 229.

${ }^{31}$ Ibid. The thirteenth-century portion of Schmidt-Beste's search was conducted on the basis of The Montpellier Codex, ed. H. Tischler (Recent Researches in the Music of the Middle Ages and Early Renaissance, 2-3, 4-5, 6-7, 8; Madison, WI, 1978-85) and Compositions of the Bamberg Manuscript: Bamberg, Staatsbibliothek, Lit. 115 (olim Ed. IV.6), ed. G. A. 
Sean Curran, 'Hockets Broken and Integrated in Early Mensural Theory and an Early Motet', Early Music History vol. 36 (2017); author's revised manuscript, accepted 4 May 2017.

Emmeram) 'imperfect hockets'. ${ }^{32}$ The search finds only 13 pieces from the Ars antiqua, ${ }^{33}$ and once again our motet does not make the cut.

In a very recent article, Wolinski has examined the musicopoetic import of hockets in thirteenth-century motets, using different case studies to the one I analyse here. ${ }^{34}$ She finds that 'hocketing helped to project the emotions expressed by a poem through increasingly nuanced and complex effects' ${ }^{35}$ I too wish to examine how motet-hockets function in relation to their texts; though my interest (complementary with Wolinski's) is in how hockets handle the motet's celebrated balance of audible and inaudible meanings. ${ }^{36}$ But from the review offered here, it would seem there Anderson (Corpus Mensurabilis Musicae, 75; Neuhausen-Stuttgart, 1977). By default, both editors render the long of three tempora as a dotted quarter note, and group them into measures of 6/8. To appear on the list, a hocket passage must therefore last for at least four perfections.

${ }^{32}$ Schmidt-Beste, 'Singing the Hiccup', p. 229.

${ }^{33}$ Ibid., p. 270. They are nos. 2, 39, 134, 180, 194, 211, 215, 234, 267, 277, and 332 in The Montpellier Codex, ed. Tischler; and nos. 36, 52, and 57 in Compositions of the Bamberg Manuscript, ed. Anderson. (Because of shared repertory between the manuscripts, Tischler's no. 39 is also Anderson's no. 36.) All of these pieces appear in my new list, offered in Appendix 2.

${ }^{34}$ M.E. Wolinski, 'Hocketing and the Imperfect Modes in Relation to Poetic Expression in the Thirteenth Century', Musica Disciplina, 58 (2013), pp. 393-411.

\footnotetext{
${ }^{35}$ Wolinski, 'Hocketing and the Imperfect Modes', p. 393.

${ }^{36}$ The literature on the motet's problems of audibility is vast. Stimulus to this sort of work was provided by Christopher Page's spirited polemic against the study of intertextual references in polytextual motets, based on the sonic difficulty of the genre. See C. Page,
} 
Sean Curran, 'Hockets Broken and Integrated in Early Mensural Theory and an Early Motet', Early Music History vol. 36 (2017); author's revised manuscript, accepted 4 May 2017.

remains a diffuse but pervasive uncertainty about how the hocket should be defined, and then identified in practice. So we must first decide on what a hocket is.

For that task, the theorists are our best guides. The first sections of this article examine their words on the hocket in close detail. I am not the first to comb their testimony. Especially important are studies by Wolf Frobenius ${ }^{37}$ and Sandra Pinegar ${ }^{38}$ which mapped the terrain; though Pinegar implicitly and Frobenius explicitly defined hocket as a multivoice phenomenon involving pitch repetition and/or voice-exchange - a definition I will challenge. ${ }^{39}$ The helpful entry for 'hoquetus' in the Lexicon

Discarding Images: Reflections on Music \& Culture in Medieval France (Oxford, 1993), pp. 65-111; and Page, 'Around the Performance of a $13^{\text {th }}$-Century Motet', Early Music, 28 (2000), pp. 343-57. Much work was stimulated by D. Pesce (ed.), Hearing the Motet: Essays on the Motet of the Middle Ages and Renaissance. New York and Oxford, 1997). Important recent contributions for the thirteenth century (each reviewing the state of scholarship) include S. Clark, “'S'en dirai chançonete": Hearing Text and Music in a Medieval Motet,' Plainsong and Medieval Music, 16 (2007), pp. 31-59; and E. Dillon, The Sense of Sound Musical Meaning in France, 1260-1330 (The New Cultural History of Music; New York and Oxford, 2012).

${ }^{37}$ W. Frobenius, 'Hoquetus', in Handwörterbuch der musikalischen Terminologie, ed. H. H. Eggebrecht (Wiesbaden, 1988).

${ }^{38}$ Pinegar, 'Textual and Conceptual Relationships among Theoretical Writings on Measurable Music of the Thirteenth and Early Fourteenth Centuries' (Ph.D diss., Columbia University, 1991), pp. 552-57.

${ }^{39}$ Pinegar (ibid., p. 552) observes that the Discantus positio vulgaris has a 'description of ochetus as an untexted voice over a tenor employing modal rhythm'; but proceeds to a discussion of Lambertus and 'the earliest extant independent hocket', the In seculum setting in E-Mn 20486 (fol. 122 ), also found in Mo and Ba, which I discussed above. The style of 
Sean Curran, 'Hockets Broken and Integrated in Early Mensural Theory and an Early Motet', Early Music History vol. 36 (2017); author's revised manuscript, accepted 4 May 2017.

musicum Latinum medii aevi also reports the usages of the early mensural theorists, though obviously does not gloss the passages; its definition begins with a multi-voice definition, but openly admits single-voice hockets too. ${ }^{40}$ Wolinski has recently offered commentaries to St Emmeram's hocket terms. ${ }^{41}$ This is all excellent, though there remains more to be said about the nuances, assumptions, and implications of the early theorists' vocabulary for discussing hockets.

In part, I seek a working definition of hocket under which to select motets for further analysis. But my emphases differ from those of previous scholarship, because I also look for evidence about how theorists listen to the device: how they describe its perceptual properties, or - in the case of the St Emmeram Anonymous - how the hocket serves within his argument about listening to measurable music more

that piece, rife with pitch repetitions and alternations between the parts, thus stands in for a general definition of the hocket. Frobenius is unambiguous: 'hoquetus', he writes, is 'd[ie] Bezeichnung einer Mehrstimmigkeit, bei der sich die Stimmen in der Hervorbringung von Tönen schnellstens abwechseln und die eine Stimme pausiert, wenn die andere Töne hat'. See Frobenius, ‘Hoquetus', col. 1.

${ }^{40}$ S.v. 'hoquetus -i m'. Lexicon musicum Latinum medii aevi, acc. 26 May 2016, URL: http://www.woerterbuchnetz.de/LmL?lemma=hoquetus. The English definition reads: “"hocket" (term for a compositional technique that is characterized by rests alternating between voices in compositions with more than one organal voice, or by repetitive use of rests in compositions with a single organal voice'. (Ibid.)

${ }^{41}$ Wolinski, 'The Medieval Hocket', The ORB: On-Line Reference Book for Medieval Studies, 2003, acc. 23 April 2016.

http://www.bestmusicteacher.com/download/wolinski the medieval hocket.pdf; and Wolinski and Haggh, 'Two $13^{\text {th }}$-Century Hockets', pp. 43-44. 
Sean Curran, 'Hockets Broken and Integrated in Early Mensural Theory and an Early Motet', Early Music History vol. 36 (2017); author's revised manuscript, accepted 4 May 2017.

generally. ${ }^{42}$ There turn out to be important divergences. Charting them reveals the discursive range enjoyed by the hocket, a device whose commentators variously found it fragmented, or a demonstration of deep integration.

Finally, theoretical auditions can be compared with the paths laid down for the ear in motets. ${ }^{43}$ I suggest that, via the words they chose, motet-composers also articulated thoughts on what hockets were good for. Analysis will show that the composer of our case-study knew and responded playfully to the full range of

${ }^{42}$ This, a move inspired by recent studies that compare literary representations of sensory experience with theorists (medieval and modern) of perception and the aesthetic. Particularly influential to my thinking have been M. Carruthers, The Experience of Beauty in the Middle Ages (Oxford-Warburg Studies; Oxford, 2013); E. Johnson, Practicing Literary Theory in the Middle Ages: Ethics and the Mixed Form in Chaucer, Gower, Usk, and Hoccleve (Chicago and London, 2013); and M. Nolan, 'Medieval Sensation and Modern Aesthetics: Aquinas, Adorno, Chaucer', The Minnesota Review, (2013), pp. 145-58.

${ }^{43}$ A locution indebted to Mary Carruthers' study of the concept of ductus as developed from Classical rhetoric by medieval thinkers. Carruthers writes, 'Ductus is the way by which a work leads someone through itself: that quality in a work's formal patterns which engages an audience and then sets a viewer or auditor or performer in motion within its structures, an experience more like travelling through stages along a route than like perceiving a whole object'. See M. Carruthers, 'The Concept of Ductus, Or Journeying Through a Work of Art', in M. Carruthers (ed.), Rhetoric beyond Words: Delight and Persuasion in the Arts of the Middle Ages (Cambridge Studies in Medieval Literature, 78; Cambridge, 2010), pp. 190-213. I make much use of this and related metaphors throughout the current article; all should be understood to allude to Carruthers' work, made so particularly germane to the case of hocket because of the frequency with which notions of vocal pathway appear in mensural theorists' accounts of the hocket. 
Sean Curran, 'Hockets Broken and Integrated in Early Mensural Theory and an Early Motet', Early Music History vol. 36 (2017); author's revised manuscript, accepted 4 May 2017.

meanings which the theorists also found in the hocket. The article's deeper aim is thus to suggest that the theoretical and creative literatures of thirteenth-century musical practice harbored points of common interest in their treatment of the hocket, interests which can be made visible by the close reading of both alongside one another. To work in this manner will entail a logical corollary, itself a claim: that a motet of the thirteenth century can be a vehicle for commentary not only about the literary but also the musical materials from which it was built. ${ }^{44}$ That claim is best made by way of demonstration. But first, to theory.

\section{Breaking}

Few will be surprised that the early theorists use terms of breaking to describe the hocket, locating it in the contrast of notes and silence. Not properly acknowledged is that they speak of the hocket as it manifests in qualities of voice and in single lines, and when they measure hockets, their scales are very small.

Perhaps the earliest description of the hocket is in the Discantus positio vulgaris. ${ }^{45}$ Hocket is mentioned only once, in a brief comment at the end of the

\footnotetext{
${ }^{44}$ This extends to their music what Sylvia Huot has taught us about motets' texts: 'the vernacular motet reflects... [an] impulse to study the vernacular corpus, to experiment with both the codification and the transformation of its generic paradigms.' S. Huot, Allegorical Play in the Old French Motet: The Sacred and the Profane in Thirteenth-Century Polyphony (Figurae; Stanford, CA, 1997), p. 10.

${ }^{45}$ The dating of the Discantus positio vulgaris is uncertain and contested. Sandra Pinegar suggests that it is unlikely to represent a stable text at all, but rather a distillation of teaching lore that circulated in the first half of the thirteenth century. (Pinegar, 'Textual and
} 
Sean Curran, 'Hockets Broken and Integrated in Early Mensural Theory and an Early Motet', Early Music History vol. 36 (2017); author's revised manuscript, accepted 4 May 2017.

treatise: 'Hocket is a diverted and consonant song [diversus et consonus cantus] above a tenor [super tenorem] in one or other of the motet modes, without words' ${ }^{46}$ For a study of the hocket in the texted genre of the motet, this might not seem promising; but though the definition may seem vague, in fact it entails logical premises which are fruitful to examine.

According to the Discantus positio vulgaris, hocket is a cantus above a tenor; so although it is a feature of polyphonic music, the hocket so defined does not include

Conceptual Relationships', p. 55.) As she explains (ibid., p. 51), the text is uniquely preserved as the first of four positiones on mensural music compiled in the Tractatus de musica of Heironymus de Moravia, itself surviving only in one manuscript (Paris, BnF Lat. 16663). Recent research clarifies that Jerome's Tractatus cannot have been written before 1275, and that the most secure terminus ante quem for Lat. 16663 is 1306: see C. Meyer, G. Lobrichon (eds.), with C. Hertel-Geay, introduction to Heironymi de Moravia: Tractatus de Musica (Corpus Christianorum Continuatio Medievalis, 250; Turnhout, 2012), pp. xiv-xvi. As Pinegar observes, 'since the Discantus positio vulgaris was edited for inclusion in Jerome of Moravia's Tractatus, its description of ochetus as an untexted voice over a tenor may not reliably be said to be the earliest theoretical description' ('Textual and Conceptual Relationships', p. 552). These cautions notwithstanding, I suspect the comment on the hocket in Discantus positio vulgaris indeed reflects early thinking. But whatever the text's vintage, its claim that the hocket is textless was evidently incorrect.

${ }^{46}$ My translation. The authoritative edition of the Latin text is now Meyer and Lobrichon, eds., Heironymi de Moravia: Tractatus de Musica, pp. 176-81. There, this passage reads: 'Item ochetus est super tenorem uniuscuiusque modi mothetorum absque prosa diuersus et consonus cantus', p. 181. For a translation of the whole text, see J. McKinnon's revised translation of O. Strunk (ed.), Source Readings in Music History, rev. ed. by L. Treitler (New York, 1998), pp. 218-223. 
Sean Curran, 'Hockets Broken and Integrated in Early Mensural Theory and an Early Motet', Early Music History vol. 36 (2017); author's revised manuscript, accepted 4 May 2017.

the tenor. Indeed, the word cantus, 'song' or often 'part', is grammatically singular here: it is qualified with the adjective diversus. Primary among Classical definitions of diversus is 'turned, pointed, or facing in different directions (from one another)', said of roads, movements, and such. ${ }^{47}$ The Oxford Latin Dictionary's seventh definition gives 'Of the opposing side (in war or other activities)' ${ }^{48}$ We might therefore suppose diversus characterises the conflict of two hocketing voices; and a reader encountering the description in the later thirteenth-century may well have understood it in that way. There is complication, however. In the vast majority of Classical examples, the adjective diversus takes a plural form, and qualifies the things which diverge from one another. ${ }^{49}$ It is difficult to reconcile such uses with the singular syntax of cantus diversus here in our text. However, diversus is also the past participle of the verb diverto, divertere, which has a slightly different semantic footprint in medieval use. Of six definitions for the verb, the Dictionary of Medieval Latin from British Sources gives first 'to divert, deflect, turn aside', a behaviour shown by journeys or routes as well as watercourses or ships; a third definition is 'to depart, betake oneself, resort', of which a listed figurative sense is 'to turn away, desist from'. ${ }^{50}$ These medieval definitions make for a much more comfortable construal that places no strain on the singular syntax of cantus diversus: a hocket is

\footnotetext{
${ }^{47}$ S.v. 'dīuersus', Oxford Latin Dictionary, combined edition (henceforth $O L D$ ), ed. P. G. W. Clark (Oxford: Oxford University Press, 1982), pp. 562-63. This definition is $§ 1$.

${ }^{48}$ Ibid.

${ }^{49}$ Ibid.

${ }^{50}$ S.v. 'divertere', Dictionary of Medieval Latin from British Sources (henceforth DMLBS), prepared by R. E. Latham and D. R. Howlett et al. (Oxford, 1975-2011), i, pp. 705-706. Diversus is not treated as a separate headword in the DMLBS.
} 
Sean Curran, 'Hockets Broken and Integrated in Early Mensural Theory and an Early Motet', Early Music History vol. 36 (2017); author's revised manuscript, accepted 4 May 2017.

the name given to that vocal phenomenon heard when a voice has been diverted from the path along which it would otherwise flow by departures from sound. ${ }^{51}$ Thus interpreted, the Discantus positio vulgaris would seem to offer (and at least to embrace) a one-voice definition of hocket.

Subsequent theorists retain a one-voice definition for some time, and often flesh it out with more detail. In the Paris version of Garlandia, ${ }^{52}$ as Edward Roesner has discussed, ${ }^{53}$ hocket is one of several colores - that is, beautiful figures adorning

${ }^{51}$ Hans Tischler suggested that diversus in this passage 'refers to the alternate sounding of notes or note groups of the one part by two performers'. See Tischler, Style and Evolution, p. 19. This idea about hockets has now been categorically dismissed by David Catalunya. See Catalunya, 'Medieval Polyphony in the Cathedral of Sigüenza', pp. 62-63.

${ }^{52}$ This, the second positio on measurable music incorporated into Jerome's Tractatus: Paris, BnF, Lat. 16663 , fols. $66^{\mathrm{v}}-76^{\mathrm{v}}$. Two manuscripts transmit another, shorter version of the treatise, that does not mention hocket. The first is Bruges, Stadsbibliotheek MS 528, $54^{\mathrm{v}}-59^{\mathrm{v}}$, which Meyer et al. date 'XIII' s. ou première moitié du XIV ${ }^{\mathrm{e}}$ s.', in The Theory of Music: Manuscripts from the Carolingian Era up to c. 1500, p. 110. The second is Vatican City, Biblioteca Apostolica Vaticana, Lat. 5325, fols. $12^{\mathrm{v}}-30^{\mathrm{v}}$, variously dated between 1260 and the early fourteenth century: see Meyer et al., The Theory of Music: Manuscripts from the Carolingian Era up to c. 1500, Addenda, Corrigenda: Descriptive Catalogue (Répertoire International des Sources Musicales, sér. B, pt. 3, vol. 6; Munich, 2003), pp. 571-72. For discussion of the sources and issues presented by the shorter versions of Garlandia, see Pinegar, 'Textual and Conceptual Relationships', pp. 78-92.

${ }^{53}$ E. H. Roesner, 'Subtilitas and Delectatio: Ne m'a pas oublié', in E. Doss-Quinby, R. L. Krueger, and E. J. Burns (eds.), Cultural Performances in Medieval France: Essays in Honor of Nancy Freeman Regalado, edited by Eglal Doss-Quinby, Roberta L. Krueger, and E. Jane Burns (Gallica 5; Woodbridge, 2007), pp. 25-43; on hocket as a color, see pp. 34-35. 
Sean Curran, 'Hockets Broken and Integrated in Early Mensural Theory and an Early Motet', Early Music History vol. 36 (2017); author's revised manuscript, accepted 4 May 2017.

melody, embracing both written and unwritten kinds of decoration. Specifically, it is a species of copula:

Copula is twofold: one kind which is the medium between organum purum and discant; the other is the one which is made in the breaking off of sounds [quae fit in abscisio sonorum], or by taking away a tempus after a tempus or tempora after tempora [aut sumendo tempus post tempus et tempora post tempora]. And this mode is taken to be wind-instrument-like [flaiolis]. And some call this mode 'hocket' [oquetum]. ${ }^{54}$

The noun abscisio derives from the verb abscidere, which in classical Latin means 'to remove by cutting', 'to amputate', or 'to fell, cut down, lop off', 55 and which is characteristically used of bodies or of trees. That violent sense remains in medieval usage, and is intensely relevant here. ${ }^{56}$ Also relevant are its connotations about the quality or sound of the voice making a hocket, for abscisio is also a term in classical

\footnotetext{
${ }^{54}$ English translations of Garlandia are adapted from Johannes de Garlandia, Concerning
} Measured Music / De mensurabili musica, trans. S. Birnbaum (Colorado College Music Press Translation Series, 9; Colorado Springs, 1978), p. 55 (henceforth 'Birnbaum [trans.]'); Latin: 'Copula duplex est, una, quae est medium inter organum purum et discantum, altera est, quae fit in abscisione sonorum aut sumendo tempus post tempus et tempora post tempora. Et iste modus sumitur flaiolis. Et aliqui vocant oquetum modum istum'; Johannes de Garlandia: De mensurabili musica: Kritische Edition mit Kommentar und Interpretation der Notationslehre, ed. E. Reimer (Beihefte zum Archiv für Musikwissenschaft, 10-11; Wiesbaden, 1972) (henceforth 'Reimer [ed.]') p. 96.

${ }^{55}$ S.v. 'abscīdo', OLD, p 10.

${ }^{56}$ S.v. 'abscedere' and s.v. 'abscisio', DMLBS, i, p. 8. 
Sean Curran, 'Hockets Broken and Integrated in Early Mensural Theory and an Early Motet', Early Music History vol. 36 (2017); author's revised manuscript, accepted 4 May 2017.

rhetoric that describes a breaking off of the voice, the rhetorical figure of aposiopesis. ${ }^{57}$ It is used this way in the manual Rhetorica ad Herennium, widely used through the middle ages. Its author writes that significatio (which in rhetoric means 'a device by which more is suggested than the words actually state ${ }^{58}$ ) may be made through abscisio if we begin to say something and then stop short, and what we have already said leaves enough to arouse suspicion, as follows: 'He who so handsome and so young, recently at a stranger's house-I am unwilling to say more'. 59

Given that Garlandia deploys a variety of rhetorical terms in this section on colores, ${ }^{60}$ the connection to the Rhetorica ad Herennium was surely deliberate: hocket involves a vocal silence pregnant with implication, produced by a sudden cutting off of sound. Garlandia's also tells us something about both the texture and the scale of the hocket when he writes that abscisio is made by 'taking away a tempus after a tempus or tempora after tempora'. This is a lateral operation performed in a single part of the polyphonic edifice: tempora are taken away after tempora given, cut from a sound ${ }^{57}$ S.v. 'abscīsiō', OLD, p. 10. The Oxford English Dictionary defines 'aposiopesis' as 'a rhetorical artifice, in which the speaker comes to a sudden halt, as if unable or unwilling to proceed'. S.v. 'aposiopesis, n.', OED Online, acc. 5 January 2016, http://www.oed.com/view/Entry/9392?redirectedFrom=aposiopesis.

${ }^{58}$ S.v. 'significātiō', $O L D$, p. 1758.

${ }^{59}$ [M. T. Cicero], Ad C. Herennium. De ratione dicendi (Rhetorica ad Herennium), trans. H. Caplan (Loeb Classical Library, 403; Cambridge, MA, 1954), p. 403. Latin: (ibid., p. 402): 'per abscisionem, si, cum incipimus aliquid dicere, deinde praedicamus, et ex eo quod iam diximus satis reliquitur suspicionis, sic: "Qui ista forma et aetate nuper alienae domi - nolo plura dicere."”

${ }^{60}$ Again see Roesner, 'Subtilitas and delectatio', pp. 33-35. 
Sean Curran, 'Hockets Broken and Integrated in Early Mensural Theory and an Early Motet', Early Music History vol. 36 (2017); author's revised manuscript, accepted 4 May 2017.

that ought to have continued like limbs from a body. There is no implication that the sound is replaced by the intervention of another part. And if hocket can manifest in even one tempus taken away after another, and not only tempora after tempora (as the contrastive formulation implies), it can be very short indeed. That may well befit its nature: Garlandia calls hocket a species of copula, a term (as Jeremy Yudkin has shown) adopted from the disciplines of Logic and Grammar which describes a verb joining subject to predicate. ${ }^{61}$ Thus we could think the hocket a transitory and connective thing - a stylistic place one passes through.

Significantly more space is given to hocket in the Ars musica by Lambertus, which must have been written before 1279, when its theories were lambasted in the

${ }^{61}$ J. Yudkin, 'The 'Copula' According to Johannes de Garlandia', Musica Disciplina: A Yearbook in the History of Music, 34 (1980), pp. 67-84; at pp. 68-71. In Yudkin's interpretation, Garlandia's copula is 'inter discantum et organum' both because it is the style logically placed between the two (having a sustained tenor note and an upper voice in modal rhythm), and because such passages are never found at the beginning of Notre Dame organa, only embedded within them. (Ibid, pp. 80-81.) One way to integrate Garlandia's general definition of the copula (which in Yudkin's reading is a substantial section of a piece, 'characterized by modal rhythm over a held tenore-tone, by sectionalization, and by melodic sequence', p. 84) with his thoughts on hocket would be to observe that Garlandia finds copula sections to be marked by the frequent use of tractūs (rests) that separate puncti (pitches or groups of pitches); on the meaning of punctus and tractus in this passage, see ibid., pp. 7678. For a contrasting view, see F. Reckow, Die Copula: über einige Zusammenhänge zwischen Setzweise, Formbildung, Rhythmus und Vortragsstil in der Mehrstimmigkeit von Notre-Dame (Mainz and Wiesbaden, 1972), pp. 54-58. 
Sean Curran, 'Hockets Broken and Integrated in Early Mensural Theory and an Early Motet', Early Music History vol. 36 (2017); author's revised manuscript, accepted 4 May 2017.

treatise of the St Emmeram Anonymous. ${ }^{62}$ Lambertus's passage on hockets concludes his treatise, and follows immediately upon the delineation of his system of nine rhythmic modes. ${ }^{63}$ Lambertus introduces hocket as follows:

Since in the above, the diversity of numerous figures and modes and many other preceding things have been discussed, now a certain 'cut-back fittingtogether' [armonia resecata] must be discussed, which as far as we are concerned is commonly called 'hocket'. ${ }^{64}$

\footnotetext{
${ }^{62}$ Yudkin convincingly defends as authorial (rather than scribal) the colophon given in the final three verses of St Emmeram, which dates the treatise to the Feast of St. Clement
} (November $23^{\text {rd }}$ ) 1279. See De musica mensurata: The Anonymous of St. Emmeram, ed. and trans. J. Yudkin (Music: Scholarship and Performance; Bloomington, 1990) pp. 32-33. On the sources for Lambertus's treatise, see The 'Ars musica' Attributed to Magister Lambertus/Aristoteles, ed. C. Meyer and trans. K. Desmond (Royal Musical Association Monographs, 27; Farnham, 2014), pp. xi-xvi (henceforth referenced 'Lambertus, Ars Musica').

${ }^{63}$ On the modes, see Lambertus, Ars musica, ed. Meyer and trans. Desmond, pp. 100-113 (Latin on the even-numbered pages, English on the odds); and on hocket, ibid., pp. 112-15. For commentary on Lambertus's modes, see Meyer's editorial introduction, pp. xxx-xxxiii; and G. A. Anderson, 'Magister Lambertus and Nine Rhythmic Modes', Acta Musicologica, 45 (1973), pp. 57-73. Meyer discusses the passage on hocket in Lambertus, Ars musica, pp. xxxiii-xxxiv. I agree with his characterization that the phenomenon 'consists of cutting a given note by a fraction of its duration' (ibid., p. xxxiii); otherwise our interpretations of the passage differ.

${ }^{64}$ My translation. Cf. Lambertus, Ars musica, ed. Meyer and trans. Desmond, p. 113.

Desmond's translation is excellent, but I have chosen nevertheless to retranslate all Lambertus quotations from scratch so as to bring out the points of connection with other 
Sean Curran, 'Hockets Broken and Integrated in Early Mensural Theory and an Early Motet', Early Music History vol. 36 (2017); author's revised manuscript, accepted 4 May 2017.

Shortly thereafter, he defines hocket, saying:

Whence it must be borne in mind that cut-back music [resecata musica], that is this very hocketation [ipsa hoccitatio], is that which is made following direct voice and relinquished [est illa que fit secundum rectam vocem et omissam], that is, when a tempus is cut off from some perfection [videlicet quando ab aliqua perfectione tempus sit resecatum]. And I say this in two senses: for sometimes the cutting is made from the part of the beginning, sometimes from the part of the end, such as is made plainly clear in writing by lines and figures in the guise of a brevity of speech [sub breviloquio]. ${ }^{65}$

There is both continuity and change in Lambertus's definition. Let us handle the continuities first.

theorists. My renditions sometimes overlap with Desmond's, sometimes diverge (corresponding pages of her translation will be one page-number higher than the reference given for a Latin quotation); she should not be held responsible for the interpretations I offer here. The Latin reads: 'Cum dictum sit superius de diversitate multiplicium figurarum et de modis et multis aliis precedentibus, nunc autem dicendum est de quadam armonia resecata, que quantum ad nos 'hokettus' vulgariter appellatur'. (Ibid., p. 112.) On the argument that Lambertus's vulgariter should be interpreted as 'in the vernacular', see Schmidt-Beste, 'Singing the Hiccup', pp. 246-47. I prefer Desmond's 'commonly' (Lambertus, Ars musica, ed. Meyer and trans. Desmond, p. 113). 'Figura' in this context means something like 'notational grapheme'.

${ }^{65}$ Latin: 'Unde notandum est quod resecata musica, id est ipsa hoccitatio, est illa que fit secundum rectam vocem et omissam, videlicet quando ab aliqua perfectione tempus sit resecatum. Et hoc dico dupliciter: nam aliquando a parte principii fit resecatio, aliquando a parte finis, prout in scriptura plane sub breviloquio per tractus et figuras declaratur'. (Ibid., ed. Meyer, p. 112.) 
Sean Curran, 'Hockets Broken and Integrated in Early Mensural Theory and an Early Motet', Early Music History vol. 36 (2017); author's revised manuscript, accepted 4 May 2017.

Breaking is basic to Lambertus's definition of hocket, just as it was to earlier writers' usages. The adjective resecata is the past participle of the verb resecāre, meaning 'to make shorter by cutting, cut back, prune, trim' in medieval Latin, ${ }^{66}$ a sense inherited from Classical texts. ${ }^{67}$ Classical figurative uses also describe the pruning of language: ${ }^{68}$ like Garlandia's noun abscisio, Lambertus's resecata connotes the cutting back of speech acts. And Lambertus, too, locates the hocket in qualities of voice or of vocal action. He distills into a noun, hoccitatio or 'hocketation', the activity of an implied verb (probably hoccitāre, 'to hocket'), ${ }^{69}$ and specifies the kinds of voice by which it is made, vox recta and vox omissa, which he has defined earlier in the treatise (along with another kind, vox cassa) ${ }^{70}$ Vox is not

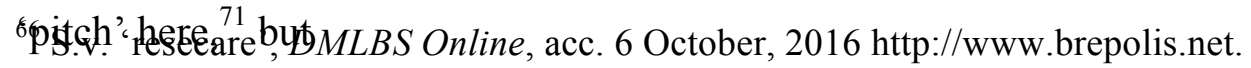

${ }^{67}$ S.v. 'resecō', OLD, pp. 1627-28.

${ }^{68}$ Ibid., $\S 1$ b, where the cited example comes from a letter of Pliny the Younger to Lupercus, concerning a speech sent in written copy along with it: the speech has grown long through zealous patriotism; but Pliny bids Lupercus 'Nevertheless, prune even these bits back as much as prudence demands'. (My translation.) Latin: ‘Tu tamen haec ipsa quantum ratio exegerit reseca'. See Pliny the Younger, Letters, Volume I: Books 1-7, trans. B. Radice (Loeb Classical Library, 55; Cambridge, MA, 1969), bk. 2, letter 5, parag. 4; p. 92.

${ }^{69}$ Though Lambertus does not use this presumed verb directly. Schmidt-Beste's translation of hoccitatio as 'hocketation' is wonderful ('Singing the Hiccup', p. 246 n. 65), and I borrow it gratefully.

70 'Whence it is to be known that a tempus comes about in three ways: sometimes in straight voice, sometimes in hollow voice, sometimes in relinquished voice'. Latin: 'Unde sciendum est quod tempus habet fieri tripliciter: aliquando enim voce recta, aliquando cassa, aliquando omissa'. Lambertus, Ars musica, ed. Meyer, p. 112. The same threefold division is drawn by Garlandia and the St Emmeram Anonymous (as identified by Meyer, ed., p. 96), but their 
Sean Curran, 'Hockets Broken and Integrated in Early Mensural Theory and an Early Motet', Early Music History vol. 36 (2017); author's revised manuscript, accepted 4 May 2017.

rather, 'voice, production of sound by the vocal organs in speaking, singing'. ${ }^{72}$ Lambertus says that vox recta is 'as the human voice proceeding from the lung[s]'.73 Rectus primarily means 'straight, not crooked', ${ }^{74}$ and used of a 'route or motion', means straight, direct, that proceeds in a straight line'. ${ }^{75}$ It brings into Lambertus's definition of hocket something of the sense of the vocal pathway from which the Discantus positio vulgaris hears the hocket deviate.

Vox omissa, by contrast, is that proportion or delay [illa proportio sive mora], in which any one of the aforementioned figures is brought about proportionally [proportionaliter habet

definitions of the terms differ from Lambertus's and from one another. Cf. Garlandia, De mensurabili musica, ed. Reimer, i, p. 38; and Anonymous of St Emmeram, De musica mensurata, ed. Yudkin, p. 102.

${ }^{71}$ A use with deep historical roots. See C. M. Atkinson, The Critical Nexus: Tone-System, Mode, and Notation in Early Medieval Music (AMS Studies in Music; Oxford and New York, 2009), p. 21 and passim.

${ }^{72}$ Its primary sense. See s.v. 'vox', §1, DMLBS Online, accessed through http://www.brepolis.net, October 6, 2016. See also E. E. Leach, Sung Birds: Music, Nature, and Poetry in the Later Middle Ages (Ithaca, NY and London, Cornell University Press, 2007), p. 25.

${ }^{73}$ Latin: 'Voce enim recta, ut vox humana procedens a pulmone'. Lambertus, Ars musica, ed. Meyer, p. 96.

${ }^{74}$ S.v. 'rectus', §1, DMLBS Online, accessed through http://www.brepolis.net, October 6, 2016.

${ }^{75}$ Ibid., $\$ 2$. 
Sean Curran, 'Hockets Broken and Integrated in Early Mensural Theory and an Early Motet', Early Music History vol. 36 (2017); author's revised manuscript, accepted 4 May 2017.

fieri] according to variation in degree [secundum magis et minus], ${ }^{76}$ and by silently reckoning in the mind the correct measure [et hoc tacite rectam mensuram excogitando] that the particular figure for its part contains within itself. $^{77}$

Omissus is the past participle of omittere, whose primary sense is 'to abandon, relinquish' a person or an action - to leave off from doing something, to give up, or even to fail in it. ${ }^{78}$ Vox omissa is also a mora: not only the "time required for doing something, ${ }^{79}$ but also the 'time that elapses before an event takes place' ${ }^{80}$ Thus Lambertus on vox omissa echoes Garlandia's hint that hocket is aposiopesis, as both theorists hear its silence freighted with anticipation of sound to come. Hocket arouses expectation, as the ear strains to hear what the breaking-off betokens. Notice, however, that Lambertus defines vox omissa both as a 'proportion' [proportio] in itself, and as that space in which a particular figure could have been brought about 'proportionately' [proportionaliter]. The emphasis signals that although vox omissa

\footnotetext{
${ }^{76}$ On magis et minus as 'variation in degree', see R. A. te Velde, Participation and
} Substantiality in Thomas Aquinas (Studien und Texte zur Geistesgeschichte des Mittelalters, 46; Leiden and New York, 1995), p. 37.

${ }^{77}$ Latin: 'Omissa autem vox est illa proportio sive mora, in qua quelibet figura superius prenominata secundum magis et minus proportionaliter habet fieri, et hoc tacite rectam mensuram excogitando secundum quod quelibet figura pro sua parte continet in se'. Lambertus, Ars musica, ed. Meyer, 96.

${ }^{78}$ S.v. 'omittere', §1, DMLBS Online, acc. 6 October 2016, http://www.brepolis.net, October $6,2016$.

${ }^{79}$ S.v. 'mora', §3, DMLBS Online, accessed through http://www.brepolis.net, October 6, 2016.

${ }^{80}$ Ibid., $\S 1$. 
Sean Curran, 'Hockets Broken and Integrated in Early Mensural Theory and an Early Motet', Early Music History vol. 36 (2017); author's revised manuscript, accepted 4 May 2017.

falls silent, it does not flounder: rather, its dimensions are quantifiable and marked by congruence, and serve as the object for mental calculation (apparently that of the singer in the time of song), here rendered with the gerund excogitando, 'by mental calculation'. Vox omissa is governed by reason. ${ }^{81}$

This conception of vox omissa is important background when Lambertus defines hocket as an armonia. Armonia may imply simultaneously sounding pitches. ${ }^{82}$ But 'fitting together' is its primary and pedigreed meaning, ${ }^{83}$ and the one Lambertus intends. ${ }^{84}$ Because armonia (then musica) resecata is the alternation of vox recta and

${ }^{81}$ Fittingly, his emphasis on vox omissa as proportion and object of reason introduces his system of seven rests, each with its own name and its own form (based on its length) by which it may be distinguished. See Lambertus, Ars musica, ed. Meyer, p. 98.

${ }^{82}$ S.v. 'harmonia -ae f.', $L m L$ online, acc. 6 October 2016. URL: http://www.woerterbuchnetz.de/LmL?lemma=harmonia. ${ }^{83}$ S.v. 'harmonia', §1, DMLBS Online, acc. 6 October 2016, http://www.brepolis.net. ${ }^{84}$ Supporting the claim that armonia (as used by Lambertus) need not imply the simultaneous sounding of multiple pitches is its use in the first half of the treatise, on musica plana. There, Lambertus distinguishes three species of musica instrumentalis: armoniaca (into which category fall both musica plana and musica mensurabilis), ritmica, and metrica (the latter two being properties of verse). (See Lambertus, Ars musica, ed. Meyer, p. 118.) The armonia which characterises musica armoniaca essentially describes any property of numerical proportion displayed between two or more musical phenomena: it may manifest between pitches (whether they are articulated together or successively), and/or between long and short notes. Thus: 'Armoniaca vero est illa que discernit inter sonum gravem et acutum, vel armoniaca est illa que consistit in numeris dupliciter et mensuris: una localis secundum proportionem sonorum et vocum, alia temporalis secundum proportionem longarum breviumque figurarum'. (Ibid.) English: 'Harmonic music, truly, is that which distinguishes 
Sean Curran, 'Hockets Broken and Integrated in Early Mensural Theory and an Early Motet', Early Music History vol. 36 (2017); author's revised manuscript, accepted 4 May 2017.

vox omissa, the proportion-based governance by reason proper to vox omissa inheres in hocket too. Lambertus's hocket is a 'cut-back fitting-together' because it alternates sound and silence proportionately. And it does so in only one voice of a polyphonic edifice. Having stated that hockets are plain to see on a staff in the alternation of strokes and figures, he later demonstrates the point by giving a notated example, which presents only a single voice-part, unidentified. ${ }^{85}$ It relays the hocket to the eye as a phenomenon communicated to the ear by a single voice. Lambertus measures hocket in terms of the individual tempus taken from a single perfection, either at its start or its end. So in keeping with tradition, his scale of hocket-measurement is minute; and the claim that hocket happens when $a$ tempus (Lambertus gives the

between a low sound and a high, or harmonic [music] is that which consists in numbers and, in a twofold manner, also in measures: one kind is based on location, according to the proportion of sounds and pitches; the other is temporal, according to the proportion of long and short figures'. (My trans.). Armonia is explicitly the object of correct, rational musical perception: 'The duty [of the musical artifex] is sometimes practical, sometimes theoretical. The practical duty, truly, is to put together harmonies [armonias componere] according to the art. The theoretical duty is to comprehend in its entirety the knowledge of the harmonic species, and that out of which they are put together, and that for which they are put together. And this, insofar as it pertains to plana musica'. (My trans.) Latin: 'Officium vero aliud practice, aliud theoretice. Practice vero est armonias componere secundum artem. Theorice officium est in summa comprehendere cognitionem specierum armoniarum, et id ex quo componuntur, et id ad quod componuntur. Et hoc quantum ad planam musicam'. (Lambertus, Ars musica, ed. Meyer, p. 118.) The final sentence makes quite clear that our own notion of 'harmony' is not identical with Lambertus's armonia, for his can manifest in one voice alone. ${ }^{85}$ Lambertus, Ars musica, ed. Meyer, p. 112. 
Sean Curran, 'Hockets Broken and Integrated in Early Mensural Theory and an Early Motet', Early Music History vol. 36 (2017); author's revised manuscript, accepted 4 May 2017.

singular form) is cut off from 'some perfection' (ab aliqua perfectione) shows that the cutting need happen only once to count.

Lambertus is also the first theorist to consider stylistic situations involving pitch-repetition and voice exchange - features which were evidently becoming prominent by his time - when talking about the hocket. But he is careful not to contradict his prior, one-voice definition of the hocket. He writes:

Whereupon complaint is to be expressed [querendum est] about how it [i.e. hocket] behaves in deed or in song [qualiter se habet in opera sive in cantu]. The refutation [responsio]: that it is sung by two, or even by so many as three [vel saltim a tribus] in order to perfect the consonance. But only by two [sed a duobus tantummodo] is a truncatio made by each of them alternating and his own voice as much recta a omissa, so that between them a pausula or some major or minor suspirium should not remain unoccupied. ${ }^{86}$

Introduced with a form of the verb queri, 'to express grievance or discontent, complain'. ${ }^{87}$ This reports an objection in indirect speech: Lambertus is answering a challenge (the challenge, perhaps, that the received one-voice definition is not compatible with these newer stylistic features?). But his vocabulary and syntax closely restrict his concession. Hocket may be sung by two, 'or even by so many as

\footnotetext{
${ }^{86}$ Latin: 'Deinde querendum est qualiter se habet in opere sive in cantu. Responsio: quod a duobus cantatur vel saltim a tribus propter consonantiam perficiendam. Sed a duobus tantummodo fit truncatio alternando unusquisque vocem suam tam rectam quam omissam, ita quod inter eos pausula vel aliquod suspirium maius et minus non remaneat vacuum'. Ibid, p. 114.

${ }^{87}$ S.v. 'queri', in DMLBS Online, acc. 6 October 2016, http://www.brepolis.net.
} 
Sean Curran, 'Hockets Broken and Integrated in Early Mensural Theory and an Early Motet', Early Music History vol. 36 (2017); author's revised manuscript, accepted 4 May 2017.

three' [vel saltim a tribus] when good consonance requires it. That it is sung by two is no barrier to the interpretation offered here: like previous commentators, Lambertus thinks of hocket as something found in parts of polyphonic edifice; thus finding hocket in two voices is not surprising. He then says that hockets with pitch repetition happen in two voices. But Lambertus does not say that hocket must show repetition of pitch when sung by two: the restrictive adverb tantummodo, 'only, merely', signals that pitch-repetitions appear only in hockets involving two voices, by which he means, not in the three-voice kinds he has just mentioned, when harmony needs to be perfected.

Moreover, the term Lambertus uses for pitch repetitions is not resecatio or armonia resecata, but truncatio, a word not found elsewhere in the treatise. It would seem it is no synonym for resecatio (which is synonymous with hoccitatio). Rather, I suggest that Lambertus's truncatio is a restricted case of two-voice interaction in which each individual voice displays resecatio, and that the theorist construes twovoice pitch-repetition in voice-exchange as two superimposed hockets. Arguing strongly in favour of this interpretation is his manner of presenting the In seculum piece: one voice at a time rather than in score. ${ }^{88}$ The first of the pair is captioned 'An example following the order and measure of the first mode', ${ }^{89}$ and the second, 'This shows the altrinsecatio against the same' ${ }^{90}$ Altrinsecatio is not used elsewhere in the treatise, or indeed in any other extant text. Perhaps Lambertus coined it, given how

\footnotetext{
${ }^{88}$ Lambertus, Ars musica, ed. Meyer, 114. Lambertus states that the hocket is in his 'first' mode, though it is actually in his third (the BLB pattern of Garlandia's second); the example was surely transmitted incorrectly.

${ }^{89}$ Latin: 'Exemplum secundum ordinem et mensuram primi modi’. Ibid., p. 114.

${ }^{90}$ Latin: 'Patet altrinsecatio contra eundem'. Ibid., p. 114.
} 
Sean Curran, 'Hockets Broken and Integrated in Early Mensural Theory and an Early Motet', Early Music History vol. 36 (2017); author's revised manuscript, accepted 4 May 2017.

aptly it makes his point. Whoever did so combined the 'cutting back' of resecatio with the Classical senses of the adverb altrinsecus, 'at or on the other side'. ${ }^{91}$ Altrinsecatio is names the one-voice hocket that is intended to be sung against another. ${ }^{92}$

Like Lambertus, St Emmeram also uses the word resecatio when speaking of the hocket, but he restricts his to hockets that break the unit-values of the prevailing (Garlandian) mode; hockets without cutting up ('sine resecatione') are those that do

${ }^{91}$ C. T. Lewis and C. Short, A Latin Dictionary, s.v. 'altrinsecus' (Oxford, 1879), p. 99. In medieval use, it can also mean 'on both sides, at both ends': see $D M L B S$, s.v. 'altrinsecus', acc. 6 October 2016, http://www.brepolis.net. But the Classical definition is the one borrowed by Lambertus for his new confection: it is, after all, used to introduce only one of the two, strikingly disaggregated voice parts.

${ }^{92}$ The St Emmeram Anonymous gives the only other attestation of altrinsecatio. It describes for St Emmeram what truncatio seems to have captured for Lambertus: the phenomenon of pitch-repetition achieved by interleaving the sounds of one part with the silences of the other. Thus St Emmeram writes: 'If such a hocketation is perfect [rather than imperfect], then it is made through the continually alternated exchange of cuttings-up [altrinsecationem resecationum] from one part to the other'. (Anonymous of St Emmeram, De musica mensurata, ed. and trans. Yudkin, p. 229, with adaptations.) Latin: 'Si sit perfecta, tunc talis hoquetatio fit per altrinsecationem resecationum ab uno cantu in alterum continue mutuatam'. Ed. Yudkin, p. 228. But see again that the resecationes belong to one part or the other; they are distinct from altrinsecatio, which describes the process by which the resecationes alternate. The three other appearances of the word in St Emmeram's text are ibid., p. 224 (lines 33 and 39), and p. 228 (line 34). 
Sean Curran, 'Hockets Broken and Integrated in Early Mensural Theory and an Early Motet', Early Music History vol. 36 (2017); author's revised manuscript, accepted 4 May 2017.

not further subdivide them. ${ }^{93}$ Six of the seven notated examples show ongoing alternation of sound and silence in two or more voices, but one has resecatio in a single part only. ${ }^{94}$ I reproduce it as Example 2, where the first and third breves of the third measure (boxed) are broken in the top part, but their silences are not filled by the middle voice. St Emmeram calls such a hocket imperfecta, 'incomplete'. Certainly the hierarchy has been inverted, and one-voice hockets are understood to deviate from an interactive, multi-voice norm. But an imperfect hocket is a hocket nonetheless, and one-voice hockets should not be excluded from modern definitions on St Emmeram's authority. St Emmeram also explicitly admits that hockets may be found in texted genres. He has much more to say about hocket than any other theorist of the thirteenth century (and indeed about everything else to do with measurable music). We will return to him in the next section.

\section{[EXAMPLE 2 NEAR HERE]}

The final theorist we shall consider, Franco of Cologne, introduces hocket in chapter 2 of the Ars cantus mensurabilis as the second of three divisions of discant: 'Discant is divided like this: the one brought forth wholly [simpliciter]; another, truncated [truncatus], which is called hocket; and another, coupled, which is named

\footnotetext{
${ }^{93}$ On which, see Wolinksi, 'The Medieval Hocket', and Wolinski and Haggh, 'Two $13^{\text {th }}$ Century Hockets on Manere Recovered', pp. 43-44. The treatise survives uniquely in Munich, Bayerische Staatsbibliothek, Clm 14523, fols. 134-159. For a description, see Anonymous of St Emmeram, De musica mensurata, ed. Yudkin, pp. 44-57.

${ }^{94}$ Munich, clm 14523, fols. $153^{\mathrm{r}-\mathrm{v}}$; the imperfect hocket is the first example on fol. $153^{\mathrm{v}}$. Cf. Yudkin ed. and trans., pp. 226-35.
} 
Sean Curran, 'Hockets Broken and Integrated in Early Mensural Theory and an Early Motet', Early Music History vol. 36 (2017); author's revised manuscript, accepted 4 May 2017.

copula' ${ }^{95}$ In chapter 13 (entirely concerned with hockets), Franco echoes

Lambertus's terms, writing that 'truncation [truncatio] is song brought forth

truncatedly [truncate prolatus] using direct and relinquished voices, ${ }^{96}$ where

truncatio is synonymous with hocket outright. ${ }^{97}$ Franco's terms derive from the verb

truncāre, perhaps the most violent of the hocket-words we have encountered.

Continuous with classical senses, the $D M L B S$ defines it first as 'to mutilate by

chopping or lopping (w[ith] abl[ative] of part removed)'; combined with the noun

capite, it means 'to behead'; and used of animals, it means 'to geld' ${ }^{98}$ Here, the

term's violence is turned on the performing voice itself, for cantus truncatus contrasts

\begin{abstract}
${ }^{95}$ For a complete English translation, see O. Strunk, rev. by McKinnon, Source Readings in Music History, rev. ed. by Treitler, pp. 226-45; this passage at p. 228. Rob C. Wegman has also rendered the whole treatise in English, presented alongside the Latin, and has kindly made it available online: 'Franco de Colonia, Ars cantus mensurabilis / Franco of Cologne,
\end{abstract} The Art of Measurable Song (c. 1280)', trans. Wegman. URL:

https://www.academia.edu/2080505/Franco_of_Cologne_The_Art_of_Measurable_Song_c.1 280_. This passage is on p. 2 of that document. Both translations are very good; I have consulted each when adapting the English reported here, and gladly acknowledge their models. Latin: 'Discantus sic dividitur: discantus alius simpliciter prolatus, alius truncatus qui oketus dicitur, alius copulatus qui copula nuncupatur', Franconis de Colonia, Ars cantus mensurabilis, ed. G. Reaney and A. Gilles (Corpus Scriptorium de Musica, 18; [Rome]: American Institute of Musicology, 1974), pp. 23-82; at p. 26.

${ }^{96}$ Adapted from Strunk/McKinnon trans., 243, and Wegman trans., p. 21. Latin: 'Truncatio est cantus rectis obmissisque vocibus truncate prolatus'. Franco, Ars cantus mensurabilis, ed. Reaney and Gilles, p. 77.

${ }^{97}$ Latin: ‘...truncatio, vel oketus quod idem est', ibid.

${ }^{98}$ S.v. 'truncare', DMLBS Online, acc. 6 October 2016, http://www.brepolis.net. 
Sean Curran, 'Hockets Broken and Integrated in Early Mensural Theory and an Early Motet', Early Music History vol. 36 (2017); author's revised manuscript, accepted 4 May 2017.

with discant simpliciter prolatus, or 'brought forth wholly', where simpliciter connotes oneness, an unbroken vocal continuity.

Only with Franco does the interleaving of sound and silence between the parts become part of the very definition of hocket:

Be it known that truncation can be made in as many manners as it happens that the long, breve, or semibreve may be divided. The long is divisible in many ways: first into a long plus a breve, and a breve plus a long; and out of this is truncation made, or hocket, which is the same thing, in such a way that if in one [voice] the breve be relinquished, in the other [voice] the long [will be relinquished]. ${ }^{99}$

truncatio 'can be made in as many manners as it happens that the long, breve, or semibreve may be divided'. ${ }^{100}$ Hocket may manifest at the level of any figure; thus it may, once again, be very small indeed, as he goes on to specify, writing that the breve 'is divisible into three semibreves or two; and out of this, hocket is sung, by

\footnotetext{
${ }^{99}$ Adapted from Wegman trans., p. 21. Latin: 'Et sciendum quod truncatio tot modis potest fieri quot longam, brevem vel semibrevem contingit partiri. Longa partibilis est multipliciter, primo in longam et brevem, et brevem et longam; et ex hoc fit truncatio, vel oketus quod idem est, ita quod in uno brevis omittatur, in alio vero longa'. Franco, Ars cantus mensurabilis, ed. Reaney and Gilles, p. 77.

${ }^{100}$ Adapted from Wegman trans., p. 21. Latin: 'truncatio tot modis potest fieri quot longam, brevem vel semibrevem contingit partiri'. Franco, Ars cantus mensurabilis, ed. Reaney and Gilles, p. 77.
} 
Sean Curran, 'Hockets Broken and Integrated in Early Mensural Theory and an Early Motet', Early Music History vol. 36 (2017); author's revised manuscript, accepted 4 May 2017.

relinquishing a semibreve in one [voice], and by bringing forth another in the other

[voice]. ${ }^{101}$ But the parts in question are two voices of a larger texture. He writes: And it must be noted that out of the said truncations common hockets are sung, out of the relinquishing and also the uttering of longs and breves. And it must be noted that in all these things [i.e. all the kinds of note-division already discussed, and all hockets] equivalence [equipollentia] in tempora must be observed, and concordance [concordantia] in direct voices. Moreover, be it known that every truncation is to be founded upon a cantus prius factus; either a vernacular or Latin song is permissible [for this purpose]. ${ }^{102}$

Let us review. Pitch repetitions and voice-exchanges abound in Parisian polyphony early in the thirteenth century, many alternating sound with silence - of that there is no question. Such effects were among the vocal techniques with which singers experimented when creating this new kind of polyphony. ${ }^{103}$ With the

\footnotetext{
${ }^{101}$ Adapted from Wegman trans., p. 21. Latin: 'Brevis vero partibilis est in tres semibreves vel duas; et ex hoc cantatur oketus, unam semibrevem obmittendo in uno, et aliam in alio proferendo', ibid., p. 78.

${ }^{102}$ Adapted from Wegman trans., p. 2; cf. Strunk/McKinnon trans., p. 244. Latin: 'Et notandum quod ex truncationibus dictis cantantur oketi vulgares ex obmissione longarum et brevium et etiam prolatione. Et notandum quod in omnibus istis observanda est aequipollentia in temporibus, et concordantia in vocibus rectis. Item sciendum quod quaelibet truncatio fundari debet supra cantum prius factum, licet sit vulgar[em] et latinum'. Franco, Ars cantus mensurabilis, ed. Reaney and Gilles, p. 79. They report 'vulgaris et latinum'; masculine accusative vulgarem, to agree with cantus prius factum, is to be preferred. ${ }^{103}$ To be clear: I see no reason to presume that such planning required notation to be achieved, at least in that earlier period. The literature on the balance of orality and literacy in
} 
Sean Curran, 'Hockets Broken and Integrated in Early Mensural Theory and an Early Motet', Early Music History vol. 36 (2017); author's revised manuscript, accepted 4 May 2017.

foregoing analysis of the theoretical tradition, however, I argue that theorists do not first describe those other phenomena, when they begin to describe the hocket. Rather, they begin by describing the sound of sudden silence in an individual voice, breaking and fracturing it, and in such a way that very small appearances count. ${ }^{104}$ Theorists (which is not necessarily to say composers) began by construing hockets one voice at a time. At least up to the time of Lambertus, a theorist might well listen to, say, a discant setting in three parts whose upper voices exchanged in a mixture of sounds and silences, and identify the piece as a hocket; but he would be able to describe it as several superimposed hockets. ${ }^{105}$ If musicians of an earlier period had another word

the Notre Dame repertory is enormous; but as I am making no argument here about the notation of the hocket per se, it is not necessary to review that literature here.

${ }^{104}$ Judith A. Peraino has pointed out that 'hocket-like fracturing of melody' is a striking feature of the monophonic descorts in MS R (see Peraino, Giving Voice to Love: Song and Self-Expression from the Troubadours to Guillaume de Machaut [Oxford and New York, 2011], p. 113) and one among several devices by which descorts 'bring the principle of discord into the body of the singer' (ibid., 114). My analysis of the theorists here lends further weight to Peraino's insightful claim. Likewise, Roesner evidently permits hockets to appear in a single voice, identifying some while analyzing the motetus of Ne m'a pas oublié (169) / IN SECULUM (M13); see Roesner, 'Subtilitas and delectatio', pp. 35-37.

${ }^{105}$ In a passing but insightful comment, Mary E. Wolinski describes the voice-exchange effects between the motetus and tenor in In Bethleem Herodes iratus (98) / IN BETHLEEM as 'interlocking hocketing between the two voices' ('Hocketing and the Imperfect Modes', p. 396). Thus she seems to hold a similar position to mine. 
Sean Curran, 'Hockets Broken and Integrated in Early Mensural Theory and an Early Motet', Early Music History vol. 36 (2017); author's revised manuscript, accepted 4 May 2017.

for that fuller texture, or recognized it as a category of its own, they left no such evidence. $^{106}$

So our love-lorn narrator's cries are back in, and to catch little hockets a finemesh net is required. I suggest that even a single texted note framed by interruption with silence is therefore a hocket, when it appears in an upper part of a motet. ${ }^{107}$ To put this in terms developed by Mark Everist for the criticism of motets, hockets need not be 'dominant' among a motet's 'modes' (that is, the elements of design a composer drew upon in a given piece) for a single use to count as a hocket nonetheless. ${ }^{108}$ I therefore propose that some 138 motet texts from the Ars antiqua

${ }^{106}$ I take no position in the debates about the origin and etymology of the word 'hocket' (let alone the origins of the practice) other than to say that all the pertinent evidence has been combed over thoroughly, and it seems to me to permit no final determination. For full discussion and a history of scholarly positions adopted, see Schmidt-Beste, 'Singing the Hiccup', pp. 246-51, who argues for an Old French etymology deriving from hoquet meaning 'hiccup', but acknowledges that no unambiguous evidence for that usage survives before the fifteenth century; and Wolinski, 'The Medieval Hocket', pp. 2-4, who finds the Old French and Latin possibilities suggested by previous scholars 'competing and viable hypotheses', (at p. 4).

${ }^{107}$ This raises the question of whether similarly isolated notes in tenor parts are also hockets. Probably so. However, our interest here is in texted parts of motets, so in the new list of motets with hockets offered in Appendix 2, I only include a piece whose tenor has restflanked notes when the tenor also has a text underlaid to the whole part, and not just a chant incipit.

${ }^{108}$ See M. Everist, French Motets in the Thirteenth Century: Music, Poetry, and Genre (Cambridge Studies in Medieval and Renaissance Music; Cambridge, 1994), esp. ch. 8, 'The Motet and Genre', pp. 148-80. 
Sean Curran, 'Hockets Broken and Integrated in Early Mensural Theory and an Early Motet', Early Music History vol. 36 (2017); author's revised manuscript, accepted 4 May 2017.

repertory be considered to contain hockets - or at least that they be spared dismissal for now, pending further analytical work. (They are listed in Appendix 2.) This figure represents a vast increase on previous tallies, but it is not in itself a mighty number: van der Werf indexes 1229 motet texts, ${ }^{109}$ of which our collection would represent only $11.2 \%$. Admitting tiny hockets has not opened floodgates - probably a good sign that the device remains marked as such.

\section{Integration}

Notions of breaking are not the whole story. To see why, we must return to the St Emmeram Anonymous.

Context is everything. St Emmeram's passage on hockets ends a defense of the six Garlandian modes against the nine proposed by Lambertus. ${ }^{110}$ He reserves particular ire for Lambertus's eighth and ninth modes, which use only semibreves: the eighth consists of pairs of unequal semibreves, and the ninth, groups of three equal ones. ${ }^{111}$ To put things briefly: St Emmeram finds Lambertus incoherent against a premiss they supposedly share, that 'a completed [or perfect; perfecta] melody cannot

${ }^{109}$ The tally was reached by counting the incipits listed in van der Werf, Integrated Directory, pp. $178-87$.

${ }^{110}$ See Anonymous of St. Emmeram, De musica mensurata, ed. Yudkin, pp. 212- 241, of which the portion on hockets is pp. 224-37. On St Emmeram contra Lambertus, see Yudkin's introduction in ibid., 7-10; and for detail about the theoretical rudiments upon which they disagree, see Pinegar, 'Textual and Conceptual Relationships', pp. 161-70.

${ }^{111}$ His passage on the modes is Lambertus, Ars musice, ed. Meyer and trans. Desmond, pp. 100-13. For further commentary, see Anderson, 'Magister Lambertus and Nine Rhythmic Modes'. 
Sean Curran, 'Hockets Broken and Integrated in Early Mensural Theory and an Early Motet', Early Music History vol. 36 (2017); author's revised manuscript, accepted 4 May 2017.

be made except by means of a completed mode, nor a perfect mode by means of imperfect figures or notes'. ${ }^{112}$ But St Emmeram has claimed that semibreves are 'so called from the adjective semus, sema, semum, which is to say, perfectus, perfecta, perfectum [i.e. incomplete] - as if they were incomplete breves'. ${ }^{113}$ Because they are only parts and never wholes, semibreves alone cannot constitute a perfect mode. ${ }^{114}$

Yet semibreves there were - long before the 1270 s - and other rhythmic subtleties to boot: dismissing Lambertus does not dismiss these (and other) rhythmic phenomena which his theory accommodates. To outflank Lambertus, it becomes St Emmeram's implicit duty to explain how the six Garlandian modes can be perceived latently in pieces (such as those rife with semibreves) where they seem not to obtain. St Emmeram tackles his problem by developing the inherited concepts of convenientia, 'agreement', and aequipollentia, or 'equivalence'; and he then turns to hockets because it is they 'through which every aequipollentia or convenientia of the figures... is perfectly distinguished and grasped [dignoscitur et habetur]'. ${ }^{115}$ Hockets showcase these fundamental forces, so we must consider their meaning to St

\section{Emmeram too.}

${ }^{112}$ See Anonymous of St. Emmeram, De musica mensurata, ed. and trans. Yudkin, p. 213, with adaptations. Latin: 'perfectus cantus non potest fieri nisi per perfectum modum, et perfectus modus nisi $<$ per $>$ perfectas figuras seu voces', ibid., p. 212. As Yudkin reports (ibid., p. 334), this is not a direct quotation from Lambertus.

${ }^{113}$ Ibid., p. 103, with adaptations. Latin: ' ... semibreves, quae de semus, sema, semum, quod est imperfectus, imperfecta, imperfectum, dicuntur, quasi imperfectae breves'; ibid., p. 102.

${ }^{114}$ This agrees with Pinegar, 'Textual and Conceptual Relationships', p. 163.

${ }^{115}$ Trans. Yudkin, p. 225, with adaptations. Latin: ‘...de hoquetis, per quos omnis aequipollentia sive convenientia figurarum... perfecte dignoscitur et habetur'. Ed. Yudkin, p. 224. 
Sean Curran, 'Hockets Broken and Integrated in Early Mensural Theory and an Early Motet', Early Music History vol. 36 (2017); author's revised manuscript, accepted 4 May 2017.

Both convenientia and aequipollentia had already enjoyed long music-

theoretical careers by the time St Emmeram wrote his treatise, and there is not space here to write their philological history. ${ }^{116}$ Suffice it for now to say that St

Emmeram's use of each term is subtle and idiosyncratic, neither sanctioned by direct precedent in mensural theory nor employed in the same sense by subsequent thinkers.

St Emmeram's convenientia is an integrative property, a fact he announces with a topic statement whose Boethian citation likens a song governed by the convenientiae specierum, the 'agreements of the modes', to a body coordinated by four humours, or to the world governed by the elements. ${ }^{117}$ St Emmeram distinguishes

\footnotetext{
${ }^{116}$ Some ground is covered by Pinegar, 'Textual and Conceptual Relationships', pp. 395-404; but the interpretations I offer here are largely incompatible with her (expressly preliminary) findings. For an overview of their uses, see s.v. 'convenientia -ae f'. In Lexicon musicum Latinum medii aevi, acc. 27 April 2016, URL:
}

http://www.woerterbuchnetz.de/LmL?lemma=convenientia; and s.v. 'aequipollentia -ae f.', in Lexicon musicum Latinum medii aevi. URL:

http://www.woerterbuchnetz.de/LmL?lemma=aequipollentia.

117 'Here the author wants to show briefly the accords of the species, saying that there are six modes or species, out of which every genus of composition is put together and occurs. And note that just as one body is brought about out of the four elements or humors by means [respectively] of the music of the universe or music of man, so, by means of the accords of species of this kind, one song, or indeed several which press on toward the same end, may beget a melody of songs as if within one body'. (Trans. Yudkin, pp. 215-17, with adaptations.) Latin: 'Hic vult actor breviter specierum convenientias declarare dicens sex esse modos sive species, ex quibus omne genus cantuum conficitur et habetur. Et nota, quod quemadmodum ex quatuor elementis seu humoribus efficitur unum corpus per mundanam musicam aut humanam, sic per convenientias huiusmodi specierum potest unus cantus seu 
Sean Curran, 'Hockets Broken and Integrated in Early Mensural Theory and an Early Motet', Early Music History vol. 36 (2017); author's revised manuscript, accepted 4 May 2017.

two kinds of convenientia, not mutually exclusive, according to musical texture. One manifests in simultaneously sounding voices, the convenientia 'of the same mode or of several modes, around several songs which press on to the same end' ${ }^{118}$ The other is the convenientia 'of several modes, this agreement being commonly attributed to the completion of one song, ${ }^{119}$ One-voice convenientia primarily handles modechange, the propensity of patterns characteristically associated with one mode to appear in a phrase primarily governed by another. As he writes, 'By this kind of convenientia, the six modes can build a unique song according to the exchanged [or perhaps changing] disposition of the person putting it together'. ${ }^{120}$ St Emmeram etiam plures ad eundem finem tendentes tanquam sub uno corpore melodiam cantuum generare'. (Ed. Yudkin, pp. 214-216.) The corresponding passage in Boethius's De institutione musica (as identified by Yudkin, op. cit., p. 334), is Book 1 ch. 2. See Anicius Manlius Severinus Boethius, De institutione musica, ed. G. Friedlein: Boethii De institutione musica libri quinque (Leipzig, 1867), pp. 187-89. For an English translation, see Boethius, Fundamentals of Music, trans. with an Introduction and notes by C. M. Bower (Music Theory Translation Series, ed. C. V. Palisca; New Haven and London, 1989), pp. 9-10.

${ }^{118}$ Anonymous of St. Emmeram, De musica mensurata, trans. Yudkin, p. 217, with adaptations. Latin: 'convenientiam eiusdem modi aut plurium circa plures cantus ad eundem finem tendentem consideratam'; ed. Yudkin, p. 216.

${ }^{119}$ Trans. Yudkin, p. 217, with adaptations; Latin: 'convenientiam plurium modorum ad perfectionem unius cantus communiter attributam'; ed. Yudkin, p. 216.

${ }^{120}$ Cf. Yudkin,p. 217; Latin: 'Si circa unum, nota, quod istae sex species per convenientiam aliquam possunt cantum unicum statuere pro dispositio mutua componentis'. Ed. Yudkin, p. 216. Apparently, St Emmeram here imports into the theory of rhythmic modes a Platonic commonplace about the affective affinity between certain melodic modes and certain people. St Emmeram's 'pro dispositio... componentis' already captures the affinity between music 
Sean Curran, 'Hockets Broken and Integrated in Early Mensural Theory and an Early Motet', Early Music History vol. 36 (2017); author's revised manuscript, accepted 4 May 2017.

claims that the new modes of the stupefacti or 'senseless people' - that is, of Lambertus - are no more than such superficial supplementations of rhythmic values, poorly understood. ${ }^{121}$ Meanwhile, convenientia between several voices concerns what we would call harmonic rhythm. ${ }^{122}$ Any horizontal combination of modes is and composer; so one wonders if 'mutua' ('mutual') is a corruption of 'mutata' (changed), which would better capture the property of change which is the foundation of the affinity of a song and its maker.

${ }^{121}$ It is worth quoting at length: 'And it does not matter whether the second species or the third, and so on for the others, are put before the first or any other in such a melody, or the reverse, or whether such species are perfect or imperfect in it, or with their own figures or strange ones, as long as the notes suitably agree or accord with the tenor of some mode placed properly beneath it. And note that such a melody, or melodies if there are more, must be judged by the same mode from which the tenor is made, if there is one found there. And some senseless people have wished to establish their modes from this kind of ordering of the melodies'. (Trans. Yudkin, p. 217, with adaptations.) Latin: 'Et non refert utrum secunda species seu tertia et sic de aliis in tali cantu priori vel alii praeponantur, aut etiam e converso, vel utrum tales species sint ibi perfectae vel imperfectae vel sub propriis figuris aut etiam alienis, dum tamen voces cohaereant seu conveniant tenori modi alicuius supposito competenter. Et nota, quod talis cantus sive tales, si sint ibi plures, debent iudicari de eodem modo de quo est tenor, si sit ibi reperire. Et de tali cantuum dispositione aliqui stupefacti modos suos statuere voluerunt'. (Ed. Yudkin, p. 216.)

${ }^{122}$ St Emmeram states openly that the first mode may not be combined with either the third or the fourth (see Yudkin, ed., pp. 216/217); and, listing the modes that do permit combination, silently omits the pairing of the first mode against the second. Yet Garlandia does permit all three of these combinations (cf. De mensurabili musica, ed. Reimer, pp. 85-86). Thus St Emmeram betrays silent disagreement with the authority he so loudly champions. He rejects the pairings on the grounds of the repugnantia vocum, the 'conflict of pitches' they produce: 
Sean Curran, 'Hockets Broken and Integrated in Early Mensural Theory and an Early Motet', Early Music History vol. 36 (2017); author's revised manuscript, accepted 4 May 2017.

permissible, and almost any vertical one, 'as long as the notes suitably cohere or accord [cohaerent seu conveniant] with the tenor of some mode placed properly [competenter] beneath it', where the true, Garlandian mode may be discovered. Thus St Emmeram's use of convenientia combines newer rhythmic and older harmonic aspects. ${ }^{123}$ It is a property of harmonious discantal motion in time.

Aequipollentia is a term imported into mensural theory from scholastic Logic, one 'referring to the equivalency of certain propositions' ${ }^{124}$ For St Emmeram, the

'yet never will the first mode be able to agree with the third or the fourth in various melodies, nor the reverse, since the conflict of the figures or pitches [figurarum repugnantia sive vocum] in these modes stands in the way of this'. (Trans. Yudkin, p. 217, with adaptations.) Latin: 'nonquam tamen primus modus contra tertium sive quartum in variis cantibus poterit convenire, nec etiam e converso, figurarum repugnantia sive vocum in eis contraria hoc obstante'. (Ed. Yudkin, p. 216). The reference to a repugnantia figurarum here seems to be a logical solecism, for as the preceding passage (quoted in $\mathrm{n} .121$ above) makes clear, the convenientia of voices renders irrelevant the figures (that is, the notational signs) in which they are written. So it is not inconsistent semiosis but poor harmony that is at stake.

${ }^{123}$ A fusion not quite captured in the separate delineation of harmonic and rhythmic senses in s.v. 'convenientia -ae f.', in Lexicon musicum Latinum medii aevi, acc. 16 October 2016, URL: http://www.woerterbuchnetz.de/LmL?lemma=convenientia. St. Emmeram is most comprehensively discussed there under the third definition: 'term that designates the ability of rhythmic modes to combine with each other'.

${ }^{124}$ Yudkin, 'The "Copula" According to Johannes de Garlandia', p. 71. For a conspectus of uses, see s.v. 'aequipollentia -ae f.', in Lexicon musicum Latinum medii aevi. URL: http://www.woerterbuchnetz.de/LmL?lemma=aequipollentia. Its primary English definition is given as 'equipollence'; the lion's share of thirteenth-century citations (including St 
Sean Curran, 'Hockets Broken and Integrated in Early Mensural Theory and an Early Motet', Early Music History vol. 36 (2017); author's revised manuscript, accepted 4 May 2017.

quality proceeds from the properties of individual unit-values: aequipollentia is the force by which any combination of notes or rests may be placed for a larger value under the prevailing mode, provided they total the same number of tempora as it would have occupied. ${ }^{125}$ The passage on aequipollentia is where St Emmeram might look most like a theorist of division, for he illustrates the property by listing many substitutions equivalent to a long of three tempora. ${ }^{126}$ Moreover, aequipollentia controls the placement of semibreves in hockets that show 'cutting up'. ${ }^{127}$ But he explicitly aims to defend a dictum he attributes to Garlandia, that 'aequipollent things must be understood in all modes', meaning that 'if a long or a breve is not used, then in its place is accepted that which is found in the place of a breve or a long'. ${ }^{128}$

Emmeram's) are presented under the second distinction offered there: 'of notes, rests, or mensural value'.

125 'By aequipollent things I mean that if a long or a breve is not found, then in its place is accepted that which is discovered in the place of the breve or the long'. (Trans. Yudkin, p. 221, with adaptations.) Latin: 'Aequipollenta, dico, ut si non inveniatur longa vel brevis, suo loco accipiatur illud, quod loco brevis vel longae repertum est'. (Ed. Yudkin, p. 220.) ${ }^{126}$ Ibid., pp. 222/223. Fascinatingly, this resembles the relation Lambertus posits between his perfect long (the basic unit of the modal system St Emmeram is attacking) and all other figures: of the perfecta figura, he writes, 'every measurable song proceeds from this figure, and is divided by it, and is replicated in it, and all the figures that ensue return to it on account of the equipollentia that is to be retained'. Lambertus, Ars musica, ed. Meyer, p. 68.

${ }^{127}$ On which, see Wolinski and Haggh, 'Two $13^{\text {th }}$-Century Hockets', pp. 43-44.

128 'For as the prose says, equipollent things must be understood in all the modes'. (Trans. Yudkin, p. 221, with adaptations.) Latin: 'Nam ut dicit prosa, aequipollenta in omnibus modis intelligenda sunt'. (Ed. Yudkin, p. 220.) The formulation is not in fact in Garlandia's treatise, though Garlandia does discuss aequipollentia and related terms frequently, e.g. offering the 
Sean Curran, 'Hockets Broken and Integrated in Early Mensural Theory and an Early Motet', Early Music History vol. 36 (2017); author's revised manuscript, accepted 4 May 2017.

Breves and longs, Garlandian modes, all the way. Aequipollentia permits the coordination and addition of the rhythmic things that build those modes; it integrates sounds that divide. Moreover, St Emmeram retroactively calls his listing of equivalences a iudicium, a judgment, about the quantity of tempora in a simplex note (in a passage, interestingly enough, which specifies that examples which should be so judged are to be found as much in texted as in untexted hockets). ${ }^{129}$ Aequipollentia permits a construal of musical sound that synthesizes it rationally.

Woven through the passages is another principle, reductio or 'reduction', something convenientia and aequipollentia together enable. ${ }^{130}$ Reductio does not

following, nearly tautological definition: 'Discant is the sounding of certain diverse parts according to the mode and according to the aequipollence of its aequipollent part'. (My trans.) Latin: 'Discantus est aliquorum diversorum cantuum sonantia secundum modum et secundum aequipollentis sui aequipollentiam'. Johannes de Garlandia, De mensurabili musica, ed. Reimer, p. 35. Garlandia's meaning is not at all clear. Lambertus uses a variant of the dictum when defining 'figure' (figura): 'Whence a figure is a representation of a sound according to its mode and according to the equipollence of its equipollent part'. Latin: 'Unde figura est representatio soni secundum suum modum et secundum equipollentiam sui equipollentis'. Lambertus, Ars musica, ed. Meyer, p. 62.

129 'The same judgment is to be considered about the other simplex figures as regards the quantity of units of time and actions in them. Indeed examples are to be sought through manifold hockets, and indeed as much in songs without text as those with'. (Trans. Yudkin, p. 223, with adaptations.) Latin: 'Idem iudicium de aliis simplicibus pro quantitate temporum et actuum in eis est habendum. Exempla quidem per hoquetos varios atque cantus tam sine littera quam cum littera sunt quaerenda' (ed. Yudkin, p. 222).

${ }^{130}$ For a preliminary overview of the term's use in other texts, see Pinegar, 'Textual and Conceptual Relationships', pp. 395-97. 
Sean Curran, 'Hockets Broken and Integrated in Early Mensural Theory and an Early Motet', Early Music History vol. 36 (2017); author's revised manuscript, accepted 4 May 2017.

make smaller rhythmic values from larger: for that, the theorist will later use the terms conversio and diminutio. ${ }^{131}$ Rather, reductio describes the cognitive action by which a varied musical surface remains unchanged in itself, but is construed in deeper and expressly Garlandian unity. For instance, having stated that discant 'rules melodies by order', a gloss to the word ordine clarifies that this is order 'with regard to the reduction of the aequipollent things to a particular mode'. ${ }^{132}$ St Emmeram's use of the term is true to its primary late classical sense, current throughout the middle ages, as an 'act of bringing back (to a proper or original position)'. ${ }^{133}$ This is continuous in

${ }^{131}$ Anonymous of St. Emmeram, De musica mensurata, ed. and trans. Yudkin, pp. 236-240. For instance, he gives an example 'of how the short mode is converted into the sixth species and extracted from the third species or the fourth by a simple conversion' (trans. Yudkin, p. 237); Latin: 'Exemplum qualiter brevis modus in sextam speciem conversus a tertia specie vel a quarta per conversionem simplicem extorquetur patet his exempliis' (ed. Yudkin, p. 236). On diminutio, e.g.: 'the same conversion should be made with the double long and with respect to its diminution, because it is converted to a breve and a long according to the second species' (trans. Yudkin, p. 241); Latin: ‘eadem conversio est de longa duplice facienda respectu diminutionis, eo quod convertitur in brevem et longam secundum speciem' (ed. Yudkin, p. 240). It is clear from context that St Emmeram finds conversio and diminutio typical of hockets.

${ }^{132}$ Thus: '...discant which... rules melodies by order.* *With regard to the reduction of the aequipollent things to a particular mode' (trans. Yudkin, p. 223, with adaptations). Latin: ‘...tanquam discantus... hos qui regit ordine* cantus. *quo ad reductionem aequipollentiarum ad aliquem modum' (ed. Yudkin, p. 222).

${ }^{133}$ S.v. 'reductio', DMLBS Online, acc. 12 January 2017, URL: www.brepolis.net. 
Sean Curran, 'Hockets Broken and Integrated in Early Mensural Theory and an Early Motet', Early Music History vol. 36 (2017); author's revised manuscript, accepted 4 May 2017.

turn with the word's root in the verb ducere, 'to lead' ${ }^{134}$ Reductio is a synthesizing mental action worked on a plural musical surface.

Reductio is also a kind of judgment, and it is the tenor which determines what the judging ear should hear. To revisit:

'we indeed judge [iudicamus] such songs from the same mode from which is the tenor, because it is the more worthy part, for from it all the others draw their origin; it is discerned [discernitur] to be the foundation to them'. ${ }^{135}$

Here the verb discernere, 'to discern' or 'distinguish', tells us this cognitive action involves perception and processing; while the verb iudicāre ('to judge') in itself, and also the worthiness imputed to the tenor (the judgment's arbiter) implies ethics. To listen discerningly for the fundamentum is a cognitive right action, morally freighted.

It was, by the thirteenth century, an old requirement that auditors listen with reason, and that in failing to do so, they would cease truly to be human. ${ }^{136}$ But St Emmeram here refracts those older notions of rationality and active perception through the prism of a much more modern, Garlandian rhythmic theory, which is set as the standard of reason - an ingenious means of asserting the auctoritas of

${ }^{134}$ For further philological information on related words, see Carruthers, 'The Concept of Ductus'. I am most grateful to Prof. Carruthers for discussing with me the interpretation of St. Emmeram's reductio I set out here.

${ }^{135}$ Trans. Yudkin, p. 217, with adaptations; emphasis mine. Latin: 'Nos siquidem tales cantus de eodem modo de quo tenor est iudicamus, eo quod sit dignior pars, nam ab ipso ducunt omnes alii originem, quibus esse decernitur fundamentum' (ed. Yudkin, p. 216).

${ }^{136}$ On which, see Leach, Sung Birds, esp. ch.1, 'Rational Song', pp. 11-54. 
Sean Curran, 'Hockets Broken and Integrated in Early Mensural Theory and an Early Motet', Early Music History vol. 36 (2017); author's revised manuscript, accepted 4 May 2017.

Garlandia's text. ${ }^{137}$ The moralizing tone rings out loud when St Emmeram inveighs against Lambertus. St Emmeram's argument, veiled but thinly, is that his antagonist has failed to listen deeply enough: in inventing new modes, Lambertus has neither captured the limitlessness of rhythmic possibilities, nor heard their underlying fidelity to Garlandian precepts. His hearing displays poor judgment, and compromises reason. That is why Lambertus is a stupefactus. ${ }^{138}$

Having declared that hockets are the most magnificent demonstration of convenientia and aequipollentia, a crucial citation of Isidore both confirms St Emmeram's departure from the theoretical consensus on hockets, and stamps a much more deeply historical seal of approval on his alternative way of understanding them.

${ }^{137}$ On St Emmeram's reverence for Garlandia, see Yudkin's introduction Anonymous of St Emmeram, De musica mensurata, pp. 10-19.

${ }^{138}$ St Emmeram wildly misrepresents Lambertus's argument. For example, Lambertus writes, 'every mensurable song is understood to belong to the likeness of divine nature in a threefold manner [extribus]. Of which the proof is evident when the threefold number is reduced [reducitur] to the perfect [number]'. Latin: 'sic omnis cantus mensurabilis ad similitudinem divine nature ex tribus constare invenitur. Cuius probatio patet in mensura ubi ternarius numerus reducitur ad perfectum'. Lambertus, Ars musica, ed. Meyer, p. 70. The belonging of three breves to the unity of the perfection is here described as a reduction; and to construe perfections in this manner is to find that they participate in the likeness of the Trinity. So Lambertus's listening is integrative and based on rhythm too, and its ethical purpose (it helps one come to know God) is more clearly defined than St Emmeram's. The theorists differ as regards what the correct object of ethical listening should be (Garlandian modes for St Emmeram, the perfection for Lambertus); but their account of how one should listen for it is very similar. 
Sean Curran, 'Hockets Broken and Integrated in Early Mensural Theory and an Early Motet', Early Music History vol. 36 (2017); author's revised manuscript, accepted 4 May 2017.

Let us return to a passage I quoted near the outset of this section, of which the full significance will now be more apparent:

'...that is to say about hockets, through which every aequipollentia or convenientia of the figures, and every kind and potency, and every knowledge, power, and nature of them is perfectly distinguished and grasped. And indeed this hocketation [hoquetatio] can by antonomasia be called harmony by us and by others. And note that 'harmony', as Isidore says, 'is the modulation of the voice and the concord or fitting together of very many sounds', which stirs and delights the minds of those listening to it, and inspires and instructs those who know and sing to understand and perform more perfectly, and put together easily, every genus of song. ${ }^{139}$

In the passage of the Etymologiae St Emmeram cites, Isidore discusses 'harmonics' (harmonica), not 'harmony' (harmonia). And in any case, harmonics concerned only matters of pitch in the voice: what we call 'rhythm' belonged to Isidore's metrics (musica rhythmica). ${ }^{140}$ Yet for St Emmeram, harmony is the hocket's essence.

\footnotetext{
${ }^{139}$ Trans. Yudkin, p. 225, with adaptations. Latin: ‘...videlicet de hoquetis, per quos omnis aequipollentia sive convenientia figurarum omneque genus et efficiacia cognitioque virtus et natura earum perfecte dignoscitur et habetur. Et nota, quod armonia, ut dicit Ysidorus, est modulatio vocis et concordia plurimorum sonorum vel coaptatio, quae audientium mentes excitat et delectat, scientes et cantantes imbuit et informat ad omne genus cantuum perfectius cognoscendum et proferendum et leviter componendum'. (Ed. Yudkin, p. 224.)

${ }^{140}$ As Yudkin identifies (op. cit., p. 315), the corresponding passage in Isidore's Etymologiae is Book III, chapter xix.2: 'Harmonics (harmonica) is the modulation of the voice and the bringing together of many sounds into agreement, or fitting them together' (Barney et al., trans., The Etymologies of Isidore of Seville, p. 96). Latin: 'Harmonica est modulatio vocis et concordantia plurimorum sonorum, vel coaptatio'. (Lindsay, ed., Isidori Hispalensis Episcopi
} 
Sean Curran, 'Hockets Broken and Integrated in Early Mensural Theory and an Early Motet', Early Music History vol. 36 (2017); author's revised manuscript, accepted 4 May 2017.

Antonomasia, then as now, is a rhetorical figure akin to metonymy, 'the substitution of an epithet or appellative, or the name of an office or dignity, for a person's proper name'. ${ }^{141}$ In medieval usage, the adverb antonomastice could also mean 'by specialized use'. ${ }^{142}$ Used in antonomasia here, the word 'harmony' communicates that hocketation (like Lambertus, St Emmeram uses the action-conveying term hoquetatio) is quintessentially a fitting together of the voice, not primarily in terms of pitch (though convenientia retains a discantal sense, as we have seen), but in time, one achieved through and instantiating convenientia and aequipollentia. And in an extension not in Isidore, St Emmeram attributes to this hocket-harmony the power to 'inspire and instruct those who know and sing to understand and perform more perfectly'. Yet again, the moral stakes are those of human reason; and the hocket is musical medium through which reason can be honed.

St Emmeram knows that his intuition will surprise, for he speaks of the hocket as if sharing a secret with a lover:

Pay attention therefore, my beloved [mi dilecte]... that you take up those things which follow with the alert ear of desire [aure vigili uringinis suscipias], and put them peacefully in the little book-case of your heart, that something

\footnotetext{
Etymologiarum, acc. 6 June 2016, URL:

http://penelope.uchicago.edu/Thayer/L/Roman/Texts/Isidore/3*.html - 20.

${ }^{141}$ S.v. 'antonomasia, n.', OED online (Oxford University Press, December 2015), acc. 9

February, 2016, www.oed.com.

${ }^{142}$ S.v. 'antonomastice', DMLBS Online.
} 
Sean Curran, 'Hockets Broken and Integrated in Early Mensural Theory and an Early Motet', Early Music History vol. 36 (2017); author's revised manuscript, accepted 4 May 2017.

understood by few and reserved with respect not be divulged indiscriminately and now become worthless. ${ }^{143}$

His secret? The hocket's fragmentation is only superficial, for it is achieved by a deep integration of parts possible only when musical time is measured. That integration is available to understanding, but it is rightly perceived only with difficulty and effort: therein lie the hocket's moral stakes. One must labor to listen with the 'alert ear of desire'. Let us call this complementarity of breaking and integration the hocket's dual character.

But let us acknowledge, too, that for all the pride with which St Emmeram lays claim to the insight, it was not his. Lambertus got there earlier: calling hocket armonia resecata (a wonderful contradiction-in-terms), he had already captured the hocket's duality of fragmentation and synthesis. St Emmeram would explore it at much greater length, and undeniably lent it sharper theoretical definition than had Lambertus. But to use the hocket's duality as a stick with which to beat him (as he did, as we have seen) was duplicitous. St Emmeram must surely have known as much.

\section{An Early Motet}

We have seen that the theoretical testimony about hockets clusters in texts whose circumstances of transmission before 1270 are only hazily visible to scholarship. However, many of the motets listed in Appendix 2 belong in family trees

\footnotetext{
${ }^{143}$ Trans. Yudkin, p. 225, with adaptations. Latin: 'Attendas igitur, mi dilecte... ut ea quae secuntur aure vigili uringinis suscipias, cordis armariolo pacifice reponendo, ne quod a paucis cognitum et honorifice reservatum est provulgatum communiter iam vilescat'. (Ed. Yudkin, p.
} 224.) Notice that the vocative dilecte is masculine. 
Sean Curran, 'Hockets Broken and Integrated in Early Mensural Theory and an Early Motet', Early Music History vol. 36 (2017); author's revised manuscript, accepted 4 May 2017.

whose roots reach into the earliest written documents of Parisian polyphony - and perhaps beyond, to the lively culture of musical making and remaking in the decades around 1200 to which, as Susan Rankin has argued, some early anthology manuscripts stand as monuments. ${ }^{144}$ Our case-study motet Dame de valour (71) / Dame vostre douz regart (72) / Manere (M5) is one such piece: though I take Mo as my copy source, the motet's earliest witness is (W2) was copied perhaps as early as the 1240 s or 1250 s (The complete list of the motet's sources is listed in Table 1). ${ }^{145}$ The remainder of this article listens to the piece closely, to suggest that motets themselves may be called as witnesses to the hocket's semantic range and practical utility, supplementing the theorists' accounts with earlier testimony. To be sure, motets may say as many things about hockets as there are pieces that use them; the hocket-motets on my list will need a longer hearing than this article alone can give them. But a generation of scholarship has given us powerful ways of listening to what early motets say, ${ }^{146}$ and I move between several of them to interpret how this ${ }^{144}$ See S. Rankin, 'The Study of Medieval Music: Some Thoughts on Past, Present, and
motet Future," in D. Greer (ed.), Musicology and Sister Disciplines: Past, Present, Future (New York, 2000), pp. 154-68.

${ }^{145}$ For a conspectus of opinions about the dating of W2, and references to further literature, see Les Quadrupla et tripla de Paris, Les quadrupla et tripla de Paris, ed. E. H. Roesner (Le magnus liber organi de Notre Dame de Paris, 1; Monaco, 1993), pp. lxxi-lxxiii.

${ }^{146}$ In addition to studies two which more specific debts will be acknowledged below, those which have left a more foundational mark on my method here include Margaret Bent, 'Polyphony of Texts and Music in the Fourteenth-Century Motet: Tribum que non abhorruit/Quoniam secta latronum/Merito hec patimur and its "Quotations", in D. Pesce (ed.), Hearing the Motet: Essays on the Motet of the Middle Ages and Renaissance (New York and Oxford, 1997), pp. 82-103; Pesce, 'Beyond Glossing: The Old Made New in Mout 
Sean Curran, 'Hockets Broken and Integrated in Early Mensural Theory and an Early Motet', Early Music History vol. 36 (2017); author's revised manuscript, accepted 4 May 2017.

works, and how the hocket functions within it. If the significance of the hocket for the St Emmeram Anonymous is best appreciated by considering its place in his idiosyncratic theoretical argument, I suggest that is true of the hocket in our motet too: that it is a carefully planned event in the motet's idiosyncratic musical and poetic arguments. ${ }^{147}$ Indeed, just as St Emmeram's argument is foundationally about correct listening, so, I contend, is the motet's.

\section{[TABLE 1 NEAR HERE]}

Some preliminaries. The score in Appendix 1 reports the musical witness of Mo, but supplies readings for verbal errors from the other witnesses listed in Table 1. ${ }^{148}$ As that table shows, W2 preserves a two-part Latin motet, Jhesu Christi sedulus (73) / Manere (M5), whose motetus shares a melody with Dame vostre douz regart

me fu grief/Robin m'aime/Portare', in D. Pesce (ed.), Hearing the Motet, pp. 28-51; Roesner, 'Subtilitas and Delectatio'; A. Zayaruznaya, The Monstrous New Art; and Zayaruznaya, 'Quotation, Perfection and the Eloquence of Form: Introducing Beatius/Cum humanum', Plainsong and Medieval Music, 24 (2015), pp. 129-66. Stimulus to this sort of work was provided by Christopher Page's spirited polemic against the study of intertextual references in polytextual motets, based on the sonic difficulty of the genre. See C. Page, Discarding Images: Reflections on Music \& Culture in Medieval France (Oxford, 1993), pp. 65-111; and Page, 'Around the Performance of a 13 ${ }^{\text {th }}$-Century Motet', Early Music, 28 (2000), pp. 343-57.

${ }^{147}$ On musical ‘events’, see K. V. Agawu, Playing with Signs: Semiotic Adventures in Romantic Music (Oxford and New York, 2009), esp. pp. 7-9 and pp. 32-33.

${ }^{148}$ For a parallel transcription of all versions and sources, see The Earliest Motets (to circa 1270), ed. H. Tischler, 3 vols. (New Haven, and London, 1982), no. 142, ii, pp. 957-62 (transcription) and iii, p. 139 (commentary). 
Sean Curran, 'Hockets Broken and Integrated in Early Mensural Theory and an Early Motet', Early Music History vol. 36 (2017); author's revised manuscript, accepted 4 May 2017.

(72). However, both Ludwig then Anderson supposed the French motet came first, ${ }^{149}$ a chronology my own philological analysis of the piece upholds, ${ }^{150}$ so Jhesu Christi sedulus will not be considered further here. Ludwig thought the French two-part version transmitted in MuA (which has Dame vostre / Manere, but no triplum) was probably a reduction of a three-part original. ${ }^{151}$ So closely do the upper-voices of the larger version interact (something we will consider shortly) that I find this the most likely chronology too - though it might be suggested that the triplum Dame de valour (71) was composed as an augmentation and an interpretative response to the tenor and motetus, and that would be fine. Finally, the word Manere is drawn from the Gradual Exiit sermo V. Sed sic eum, sung at Mass on the Feast of St John the Evangelist

${ }^{149} \mathrm{~F}$. Ludwig, Repertorium organorum recentioris et motetorum vetustissimi stili, 2 vols. [Halle, 1910; repr. and ed. L. Dittmer, Broooklyn, NY, 1964, 1972 and 1978], 1.i, pp. 196-97 and 283); G. A. Anderson, The Latin Compositions, i, pp. 296-99).

${ }^{150}$ Dame vostre douz regart (72) and Jhesu Christi sedulus (73) show the same rhyme scheme (though use different rhyme sounds), except in their verses 10 and 11 . These are set to the 2 two-note phrases of the hocket. In the French, each carries a disyllabic word with b-rhyme ('aler / parler'); in the Latin, they introduce a new, d-rhyme, formed from the internal vowels of two words broken over the phrase-ends ('previ- / -e fi- / [dem]'; see W2, fol. 182 ${ }^{\mathrm{v}} .2$ ). Such syllable division is unusual; and the first broken word (previe) has the Latin text's original disyllabic b-rhyme [-ie], as if to acknowledge that it was desirable but impossible to use brhyme at the end of verse 10 (because the phrase had only two notes, and ie alone is not a word). It is hard to imagine how these quirks would have come about except by modelling the Latin text (poorly) on the French. On philological ways of determining motet chronologies, see Bradley 'Contrafacta and Transcribed Motets'.

${ }^{151}$ Ludwig, Repertorium, 1.i, p. 283. 
Sean Curran, 'Hockets Broken and Integrated in Early Mensural Theory and an Early Motet', Early Music History vol. 36 (2017); author's revised manuscript, accepted 4 May 2017.

(December $\left.27^{\text {th }}\right){ }^{152}$ The lucid structure of its setting as a tenor can be

straightforwardly accounted for. All 36 notes of the chant's Manere melisma are used in the motet's cursus, disposed into 12 three-note ordines in the rhythmic pattern BLB (Garlandia's second mode). The entire cursus is stated twice. ${ }^{153}$ Appendix 1 lays the motet out on two facing pages, with equivalent positions in each cursus placed opposite one another.

The tenor is also the deep source of our motet's stance on listening, but to hear why requires deeper contemplation. Here is the text of the source chant, the Gradual Exiit sermo V. Sed sic eum:

\begin{tabular}{|l|l|}
\hline $\begin{array}{l}\text { [Respond:] Exiit sermo inter fratres quod } \\
\text { discipulus ille non moritur. }\end{array}$ & The rumour went out among the brethren \\
\hline $\begin{array}{l}\text { tVerse: }] \text { Sed sic eum volo manere donec } \\
\text { veniam tu me sequere. }\end{array}$ & But 'So I will have him remain until I \\
\hline
\end{tabular}

${ }^{152}$ For a list of chants set polyphonically at Paris c. 1200 and their liturgical settings, see C. Wright, Music and Ceremony at Notre Dame of Paris, 500-1500 (Cambridge, 1989), pp. 259-62. The surviving Parisian polyphony for M5 is indexed in van der Werf, Integrated Directory, pp. 19-21.

${ }^{153}$ The version of Exiit sermo known to Parisian musicians in our period is readily available online: Paris, BnF Latin 1112 (at fol. $156^{\mathrm{r}}$ ). URL:

http://gallica.bnf.fr/ark:/12148/btv1b6000450z/f321.item (accessed March 29, 2016).

${ }^{154}$ Transcribed from BnF Latin 1112, fol. $156^{\mathrm{r}}$.

${ }^{155}$ Translation based on The Holy Bible: Douay-Rheims Version (Charlotte, NC: Saint Benedict Press, 2009), New Testament, p. 132. 
Sean Curran, 'Hockets Broken and Integrated in Early Mensural Theory and an Early Motet', Early Music History vol. 36 (2017); author's revised manuscript, accepted 4 May 2017.

The chant summarizes the point of a longer gospel passage, John 21:20-23. ${ }^{156}$ Peter, walking with Jesus, sees John behind them and asks, "Lord, what shall this man do?", 157 (verse 21). Jesus replies: "“So I will have him to remain [sic eum volo manere] till I come, what is it to thee? Follow thou me",158 (verse 22). Not without reason, the disciples are confused. As the Evangelist relates:

[23.] This saying therefore went abroad [exiit ergo sermo iste] among the brethren, that that disciple should not die [non moritur]. And Jesus did not say to him that that disciple should not die [quod discipulus ille non moritur]; but, 'So I will have him to remain [manere] till I come, what is it to thee?'159

The passage constitutes a study in faithful versus casual repetition of messages received, and a lesson in disambiguation. Thus at the start of verse 23 the disciples' confusion becomes a sermo (which among several definitions, means 'remark, saying,

${ }^{156}$ This passage formed part of the Gospel reading at Mass on the Feast of St. John (John 21:19-24), so I supply the Latin from BnF Latin 1112, fol. $156^{\mathrm{r}}$, silently expanding abbreviations, so as to preserve the textual variants in the scripture alongside which the chant would have been heard. For a modern edition, see Biblia sacra vulgata, ed. Weber-Gryson, p. 1697; the English translation is based on The Holy Bible: Douay-Rheims Version, New Testament, p. 132, with some adaptations.

${ }^{157}$ John 21:21. Latin (BnF Lat. 1112, fol. 156 ${ }^{\mathrm{r}}$ ): 'Hunc ergo cum vidisset Petrus; dixit Iesu. Domine; hic autem quid?'

${ }^{158}$ John 21:22. Latin (BnF Lat. 1112, fol. 156 ) : 'Dixit ei Iesus. Sic eum volo manere; donec veniam. Quid ad te? Tu me sequere.'

${ }^{159}$ John 21:23. Latin (BnF Lat. 1112, fol. $156^{\mathrm{r}}$ ): 'exiit ergo sermo iste in fratres; quod discipulus ille non moritur. Et non dixit ei Iesus non moritur; sed sic eum volo manere donec veniam quid ad te.' 
Sean Curran, 'Hockets Broken and Integrated in Early Mensural Theory and an Early Motet', Early Music History vol. 36 (2017); author's revised manuscript, accepted 4 May 2017.

utterance' or 'talk'; 'account ${ }^{160}$ ) that enters into circulation as a faulty rumour at the start of verse 23 , to be stamped out quickly before the same verse ends; it is contrasted retroactively (in verse 24) with the verum testimonium ('attestation', 'testimony') of John's witness. ${ }^{161}$ Notice the careful syntax of the passage. By taking sermo itself as the grammatical subject (verse 23) the Evangelist tactfully skirts over who, precisely, is at fault for this gossip-mongering; the sermo becomes an impersonal sort of speech, spoken by several people but owned by none.

Complementarily, he encases the rumour's content, 'non moritur', in an indirectspeech construction (introduced with quod yet with a finite verb in the indicative, as usual in the Vulgate ${ }^{162}$ ), as if not wanting to utter the sermo (except to refute it, as he does next) lest that fuel its flight, or compromise the authority of his voice. Its syntactic muffling sharpens the imagined sound of manere: a word spoken by Christ, reenvoiced by the Evangelist twice over, the second iteration landing an emphatic contradition to the nonsense of non moritur. The point, of course, is to demonstrate that John is a transparent and reliable medium for a divine message. And the translation brilliantly distills the whole process -- both the corruption into error and its correction -- into a property of linguistic sound: whatever Aramaic words Jesus spoke,

${ }^{160}$ S.v. 'sermo', DMLBS.

${ }^{161}$ Vulgate: 'hic est discipulus qui testimonium perhibet de his et scripsit haec et scimus quia verum est testimonium eius.' English (Douay-Rheims): 'This is that disciple who giveth testimony of these things, and hath written these things; and we know that his testimony is true.'

${ }^{162}$ On which, see A. G. Rigg, 'Morphology and Syntax', in F. A. C. Mantello and A. G. Rigg (eds.), Medieval Latin: An Introduction and Bibliographical Guide (Washington, D.C., The Catholic University of America Press, 1996), pp. 83-92, at p. 86. 
Sean Curran, 'Hockets Broken and Integrated in Early Mensural Theory and an Early Motet', Early Music History vol. 36 (2017); author's revised manuscript, accepted 4 May 2017.

their rendering in Latin (via Greek) makes moritur and manere seem the source of the confusion, as if someone failed quite to catch a three-syllable word starting with ' $\mathrm{m}$ ', and took a guess at it incorrectly before passing the message on. At the root of the problem lies faulty listening, and that is the error the second and emphatic 'manere' — the one quoted in the chant, and taken as our motet's tenor — seeks to put right. Insofar as our French motet makes no reference to John the Evangelist, our poet-composer ignored the chant's festal context. But he listened to its scriptural context very closely indeed, crafting in response to it a motet whose upper voices playfully meditate on sayings that travel inaccurately or in variant forms. The point of connection is the word sermo. Both in general and in the specific manner it is handled in the gospel text, it makes an apt Latin counterpart to what we call the 'refrain', 163

${ }^{163}$ As J. A. Peraino aptly observes 'refrains operate much like proverbs; they are aphorisms circulating freely in the public domain, representing a public voice.' (Giving Voice to Love, p. 197.) It may be useful to clarify what I mean by 'refrain'. Refrains (as Suzannah Clark lucidly characterises them) are 'textual and melodic entities, ranging from one word to a couple of lines long, which are incorporated into a host genre' (Clark, "'S'en dirai chançonete", p. 45). Refrains may or may not also be quotations, either in whole (i.e. as represented in the various refrain catalogues), or in part (at the level of formula in text and/or melody), as when melodic units recur in several catalogued refrains, with citational force (on which see Butterfield, 'Repetition and Variation'; and Clark, “'S'en dirai chançonete,"” pp. 44-54). For another perspective on identifying refrains, which makes demonstrable quotation a more important criterion defining the category, see Everist, French Motets, pp. 54-66. There is a large and lively literature on refrains, but two excellent recent accounts render another unnecessary here: see Clark, "'S'en dirai chançonete", pp. 44-48; Saltzstein, The Refrain and the Rise of the Vernacular, pp. 1-34. 
Sean Curran, 'Hockets Broken and Integrated in Early Mensural Theory and an Early Motet', Early Music History vol. 36 (2017); author's revised manuscript, accepted 4 May 2017.

and which thirteenth-century people often called a 'motet'. ${ }^{164}$ Our polyphonic motet concludes with two refrains, one in each upper voice, both unica. In the most recent census (by Anne Ibos-Augé and Mark Everist) the motetus's refrain (bb. 41-48 in Appendix 1's score) is indexed as 'vdB 1233a*, ${ }^{165}$ and the triplum's (bb. 39-48) as 'vdB 238'. ${ }^{166}$ I use those numbers for reference from here on. ${ }^{167}$ Example 3 analyses them in parallel. I give their texts again here, now with versification markers that relate them to one another (rather than relating each to the rhyme-scheme of its motetvoice): ${ }^{168}$

\footnotetext{
${ }^{164}$ On which most recently, see Peraino, Giving Voice to Love, p. 197.

${ }^{165}$ S.v. 'vdB 1233a*', by Anne Ibos-Augé and Mark Everist, in Music, Poetry, Refrain: The Medieval Refrain (accessed February 15, 2016), URL:
}

http://refrain.ac.uk/view/abstract item/1233a=2A.html. This resource is based on, and updates, the index by N. H. J. van den Boogaard, Rondeaux et refrains du XII siècle au début $d u X I V^{e}$ (Bibliothèque Française et Romane, Série D: Initiation, Textes et Documents, 3; Paris, 1969), whence derives the identifier 'vdB'.

${ }^{166}$ S.v. 'vdB 238', by Anne Ibos-Augé and Mark Everist, in Music, Poetry, Refrain: The Medieval Refrain (accessed February 15, 2016), URL:

http://refrain.ac.uk/view/abstract_item/238.html.

${ }^{167}$ The refrains are also indexed by F. Gennrich, Bibliographisches Verzeichnis der französischen Refrains (Summa musicae medii aevi, 14; Langen bei Frankfurt, 1964); vdB $238=$ Gennrich $1420 ; \operatorname{vdB} 1233 \mathrm{a}^{*}=$ Gennrich 1421.

${ }^{168}$ Although unaccented terminal - $e$ may not always have been sounded in spoken Old French, it is handled as a syllable by composers (when not elided with a following vowel), its pitches written with their own figure by scribes; thus I include it in my syllable counts, even though editorial convention for Old French texts would usually omit it. E.g. I count verse 13 
Sean Curran, 'Hockets Broken and Integrated in Early Mensural Theory and an Early Motet', Early Music History vol. 36 (2017); author's revised manuscript, accepted 4 May 2017.

Motetus refrain: vdB 1233a*

Li maus d'amer me debrise, $\quad 8$

The pain of love is breaking me,

Et la [douleur que je sent.] $\quad 7 \mathrm{~b} \quad$ And the suffering that I feel.

\section{Triplum refrain: vdB 238}

$\begin{array}{lcl}\begin{array}{l}\text { Bele, douce amie, } \\ \text { loiaument, }\end{array} & 6 \mathrm{a}^{\prime} & \text { Beautiful, sweet sweetheart, } \\ \text { cuer et cors et vie } & 3 \mathrm{~b} & \text { Loyally } \\ \text { Tot voz rent. } & 6 \mathrm{a}^{\prime} & \text { Heart and body and life } \\ & 3 \mathrm{~b} & \text { I render unto you. }\end{array}$

\section{[Example 3 NEAR HERE]}

The refrains' most striking feature is the degree to which they share phonetic and melodic materials, and then lend them to the voice-parts onto which they are 'grafted'. ${ }^{169}$ Ironically, Mo's text scribe confused the two refrains, though he

of Dame vostre doz regart as 8 syllables, rather than notating it 7'. I am grateful to Bill Burgwinkle for discussing this with me.

${ }^{169}$ On this conception of 'grafting' (which translates the Old French horticultural term enté, used by some thirteenth-century witnesses in relation to motets and refrains, among other hybrid creative forms), see Butterfield, 'The Language of Medieval Music: Two ThirteenthCentury Motets', Plainsong and Medieval Music, 2 (1993), pp. 1-16; Butterfield, 'Enté: A Survey and Reassessment'; and Peraino, Giving Voice to Love, pp. 186-229. For another view, see Everist, French Motets, pp. 54-66. 
Sean Curran, 'Hockets Broken and Integrated in Early Mensural Theory and an Early Motet', Early Music History vol. 36 (2017); author's revised manuscript, accepted 4 May 2017.

recognised his error; ${ }^{170}$ but his mistake points out how alike they sound. (See

Example 3.) Each consists of musical two phrases. ${ }^{171}$ In vdB 1233a*, each sets one poetic verse, giving the structure $8 \mathrm{a}+7 \mathrm{~b}$, while each phrase of vdB 238 sets two, producing the structure $\left(6 a^{\prime}+3 b\right)+\left(6 a^{\prime}+3 b\right)$. Moreover, the two refrains share their $b-$ rhyme [-ent], while — significantly — their disyllabic a-rhymes are almost but not quite the same too ([-ise] in vdB 1233a*, [-ie] in vdB 238). This detail is a nod to the scriptural source: via an imperfect reproduction of the refrains' rhyme contrast, something of the sound of one is captured and repeated by the other (twice over, in the case of vdB 238), like manere transformed into moritur and going out among the disciples. ${ }^{172}$ And as in their rhymes, so in the refrains' melodies. Their first phrases

${ }^{170}$ At Mo, fol. 130 r 4 , the motetus's conclusion reads 'vie tout voz rent', which should conclude vdB 238; while opposite (fol. 129 $9^{\mathrm{v}} .4$ ), an extraneous syllable yields 'savie tout voz rent' in the triplum. The scribe underlined the motetus's error and left a correction sign in the margin. Collation makes correct versions obvious. For vdB 1233a*: MuA ('et la dolor qe ie sent') and $\mathrm{Cl}$ ('et la douleur que ie sent') agree against an error in W2 ('et les douz maus qe ie sent': an asyntactic repetition of 'maus' from verse 13); so I supply Cl's orthography. Across all three sources of vdB 238 (W2, Mo, Cl), Mo's extraneous syllable is the only verbal disagreement, and can be omitted.

${ }^{171}$ Though there is no rest between the two phrases of vdB $1233 \mathrm{a}^{*}$, the scribe signals their division into phrases with a stroke, marked in the transcription by a comma above the staff. ${ }^{172}$ On hermeneutic properties of linguistic sound supplementary to a motet-text's semantic meaning, see Emma Dillon, The Sense of Sound: Musical Meaning in France, 1260-1330 (New York and Oxford, 2012). On the aesthetic motif of imperfect musical reproduction in fourteenth-century songs, see E. E. Leach, 'Nature's Forge and Mechanical Reproduction'; and in later repertories, C. Abbate, In Search Of Opera (Princeton, 2001). My reading is indebted to all three studies. 
Sean Curran, 'Hockets Broken and Integrated in Early Mensural Theory and an Early Motet', Early Music History vol. 36 (2017); author's revised manuscript, accepted 4 May 2017.

each begin with the tag $e^{\prime} f^{\prime} g$ '[BBB] (which I label $x$ ); each articulates $a$ ' at the start of its third perfection (with a pitch repetition, $a^{\prime} a^{\prime}[\mathrm{BL}]$ in $\mathrm{vdB} 1233 \mathrm{a}^{*}$ ); and each shares a common registral goal of $c$ ', marking it with a figuration that involves semibreves in fractio modi. Again, these are almost but not quite the same in each part. Both use $b^{\prime} a^{\prime} c$ ' $[\mathrm{SSB}]$ in the place of the underlying second-mode long; vdB $1233 \mathrm{a}^{*}$ also fractures the preceding breve into two semibreves, $b^{\prime} c$ ' $[\mathrm{SS}]$ (which I label $y$ ), whereas vdB 238 lands directly on an unfractured $c^{\prime \prime}[\mathrm{B}]$ (my $\left.y^{\prime}\right)$.

Each refrain's second phrase works a different formal 'outcome' from the musical stimuli their first phrases share. In vdB 1233a*, the start of the second phrase is rhymed with its first by a repetition of its melodic opening, motive $x{ }^{173}$

${ }^{173}$ The other sources of the motet introduce some fascinating variants for vdB $1233 \mathrm{a}^{*}$; they are recorded in The Earliest Motets, ed. Tischler, ii, no. 142, pp. 957-62, with commentary in vol. iii, p. 139. There is not space to discuss them in full; though I suspect that comparing how refrain unica behave across copies of their single host motet may yet shed more light on issues of refrain transmission beyond the written record. Suffice it to say in the current case that the formal rhyming achieved in vdB 1233a* by motif $x$ at bb. 41 and 45 (as per Mo) copy is most likely to be authorial. It is manifest also by the Latin contrafact W2(b), using the slightly different tag $e^{\prime} f^{\prime}[\mathrm{BL}]$ in both positions (bb. 41 and 45). Both Mo and W2(b) therefore open with a dissonant second against the tenor's $d$ ' (b. 41). Importantly, all sources use either $e^{\prime} g$ '[BL] (MuA, Cl, W2(b)) or motif $x$ (W2[a], Mo) at b. 45. W2(a), MuA, and $\mathrm{Cl}$ all report $f^{\prime} g$ ' $[\mathrm{BL}]$ at b. 41, yielding a more consonant third with the tenor. I find it more likely this resulted from recension by scribes or singers who valued consonance over citational effect, than that the versions beginning with $e$ ' represent independent errors from a consonant original that serendipitously yielded a formal symmetry. Mo's e'f'g '[BBB] version of $x$ is probably the version taken by the motet's composer: it opens vdB 238 also (b. 39) in the witness of both $\mathrm{Mo}$ and $\mathrm{Cl}$ (against W2[a]'s $e^{\text {' }} \mathrm{g}$ '[BL]); and lies behind the sequentially 
Sean Curran, 'Hockets Broken and Integrated in Early Mensural Theory and an Early Motet', Early Music History vol. 36 (2017); author's revised manuscript, accepted 4 May 2017.

chiasmatically, the second phrase of $\mathrm{vdB} 238$ is rhymed with its first by use of its melodic goal, motive $y^{\prime} \cdot{ }^{174}$ Other reminiscences and relations could be pointed out (the sequential use of the contour of $x$ in each phrase of vdB 238, for example). But the formal chiasmus traced by these exact repetitions is an especially artful contrivance, and suggests both refrains bear the marks of ad casum formal shaping. Either one served as the model for the other, or both were composed from the same stuff in the making of this motet. ${ }^{175}$ In either scenario, the refrains might also borrow from a shared stock of citational formulae, rigging them across the different frames of their texts.

But we would not need to find citations beyond this motet to admit readily that the material of the refrains does citational work within it. Ardis Butterfield observes that refrain citations show 'a tendency towards instability, since there is a large degree curving, ascending contour with which both of vdB 238 's phrases begin. One wonders if a citational fragment of melody was indeed in broader circulation, and that the $e^{\prime} g$ ' variant was another acceptable way of capturing it in writing that singers or scribes transmitting our motet might have known.

${ }^{174}$ The triplum in Mo has one statement of $y$ (b. 35) and five statements of $y$ ' (bb. 1, 18, 22, 42, 46): in every case, W2(a) and $\mathrm{Cl}$ are in precise agreement with Mo. The motetus only sings the variant $y$, and only twice (bb. 40 and 44). At b. 44, Mo, W2(a) and W2(b) all report $y$, though $\mathrm{Cl}$ has $y^{\prime}$, and $\mathrm{MuA}$ the otherwise unattested variant $b^{\prime} g$ ' $[\mathrm{BL}]$. But at b. 40 , all sources except W2 agree in reporting $y$ exactly; the formal rhyming with b. 44 was surely intended and argues powerfully that $y$ was was the original version of this figure taken by the motet's composer. Again, one wonders if the variations across the motet's sources indicate broader circulation of this citational formula.

${ }^{175}$ Clark analyses how refrains may be composed in the course of making a motet in " $S$ 'en dirai chançonete,"” pp. 44-54. 
Sean Curran, 'Hockets Broken and Integrated in Early Mensural Theory and an Early Motet', Early Music History vol. 36 (2017); author's revised manuscript, accepted 4 May 2017.

of small-scale variation, yet also towards stability, since these very slightly distinctive features are often themselves repeated exactly'. ${ }^{176}$ It is precisely this contradiction upon which our motet plays, one brought to awareness and subjectivated as a response to the motet's tenor. For the refrains are sculpted and positioned to do in performance what Suzannah Clark has called 'intersonic' work: ${ }^{177}$ vdB 238 begins at b. 30 , and, introduced by an extra use of $y$ in the motetus at b. $40, \operatorname{vdB} 1233 \mathrm{a}^{*}$ starts at b. 41 , with the result that the $y$ and then $y^{\prime}$ motifs echo one another between the parts with a regular periodicity of two perfections, ${ }^{178}$ their likeness and contrast on audible display at the top of the texture.

Moreover, elements of the refrains both accurate and distorted ring throughout the motet, with the effect of variations heard before a theme whose identity they put in question: they play a game called 'What will my refrain be?' - and perhaps, when we get two, a game called 'Which is the true one?"179 The score in Appendix 1 marks all iterations of the refrain motives $y$, and $y^{\prime}$ in ovals, while two kinds of dashed boxes highlight two further figurations that are kin with them in that all place fractiones for the second-mode long, and that carry intersonic calls between the parts. ${ }^{180}$ Especially

\footnotetext{
${ }^{176}$ Butterfield, Poetry and Music, pp. 85-86.

${ }^{177}$ Clark, "'S'en dirai chançonete", p. 59.

${ }^{178}$ Thus: b. 40, motetus, $y$; b. 42 , triplum, $y^{\prime}$; b. 44, motetus, $y$; b. 46, triplum, $y^{\prime}$.

${ }^{179}$ Relevant here is Michel Zink's suggestion that 'that the prehistory of literature is above all a trompe l'oeil creation of literature itself. It is the texts themselves that send their reader on a wild goose chase for their antecedents.' Zink, The Enchantment of the Middle Ages, trans. J.

M. Todd (Parallax: Re-Visions of Culture and Society; Baltimore and London, 1998), p. 13.

${ }^{180}$ To avoid clutter I do not include variants which can be heard to echo $x$; but using the B-BB fractio pattern ubiquitous in the second rhythmic mode as a formal tag in $\mathrm{vdB} 1233 \mathrm{a}^{*}$ and the opening of vdB 238 has the effect that almost any use of the rhythm, especially in conjunct
} 
Sean Curran, 'Hockets Broken and Integrated in Early Mensural Theory and an Early Motet', Early Music History vol. 36 (2017); author's revised manuscript, accepted 4 May 2017.

using this set of figurations, the two singers play at call-and-response, now repeating one another exactly, now inexactly, sometimes with regular periodicity, sometimes as an unpredicted interruption. For example, the motetus's descending g'f'e'd'c[SSSSB] figure in b. 7 is repeated by the triplum in b. 9, inaugurating a chain of imperfect fractio replies at two-perfection intervals: the motetus's $y$ ' at b. 11, then the triplum's high $a^{\prime} b^{\prime} a[\mathrm{SSB}]$ turning motif at b. 13 . That figure is then repeated precisely by the triplum b. 16 at the longer interval of $3 \mathrm{P}$, only to be exactly parroted with interruptive force one perfection later by the motetus at b. $17,{ }^{181}$ which is answered by the triplum's $y^{\prime}$ at b. 18. This is all the more comic in that their texts give little sign that the two narrators hear one another, and no one part consistently follows the other's lead; rather, they report musical messages as if unaware of their origin. As the motet unfolds, then, we hear the refrains' variant bits - like so many little sermones disseminate like rumour. Heard this way, the motet models in miniature the world of indeterminate circulation through which refrains in general turned, and in which a message sent might or might not be the message received.

It is little wonder their songs have so much in common: the narrator of the triplum has been wounded by the Lady's loving look too. Though we have to wait until his tenth

ascent, could be heard as a sonic premonition of the refrains. To decide which such uses are and are not internal citations is more than usually arbitrary, and that is quite to the motet's point.

${ }^{181}$ A grateful allusion to E. E. Leach, Sung Birds: Music, Nature, and Poetry in the Later Middle Ages (Ithaca, 2007); we will shortly see that this figure, as sung by the motetus, signals its narrator's distress. 
Sean Curran, 'Hockets Broken and Integrated in Early Mensural Theory and an Early Motet', Early Music History vol. 36 (2017); author's revised manuscript, accepted 4 May 2017.

verse for a verb ('a... navré', 'has wounded') for clarification, the triplum's music implies it as early as b. 4 , for he sings the word 'regart' to a descending semibreve figure that echoes inexactly the figure his friend has just sung to the same word in bar 3. ${ }^{182}$ Yet from their common point of narrative departure (notice they sing the word Dame simultaneously the motet's first bar), they bring about very different songs: the motetus adopts the stance of a complaint, while the triplum would seem to make a lover's overture in the manner of the 'High Style' trouvère song. ${ }^{183} \mathrm{We}$ are invited to take what separates the narrators as an alternative object of listening over the first seven perfections, in which are two statements of $y^{\prime}$ in the triplum (bb. 1 and 4, the second transposed to start on $g^{\prime}$ ), and two of a fractio variant that descends from $g$ ' to $c^{\prime}$ in the motetus (bb. 3 and 7, in dashed rectangles in Appendix 1). Each figure articulates a phraseological parallel within its own part: $y$ ' links the opening of the triplum's first two phrases, (bb. $1-3^{1}$ and bb. $4-6^{1}$ ); the other figuration rhymes the third perfections of the motetus's (bb. $1-4^{3}$ and bb. $5-8^{1}$ ). But the two parts phrase with different periodicities to produce the inexact echo linking the word 'regart' in each part at bars 3 and 4 , tempting the ear to follow the citational prompt across the texture, rather than to follow how the figurations build up shapes in each part over time. That is a choice the piece makes available again and again - one akin to the

${ }^{182} \mathrm{Cf}$. Appendix 1, motetus, verse 1; triplum, verses 2 (with ambiguous syntax) and 10 (where a compound verb in the third-person singular, 'a... navré', clarifies that what has been heard thus far is ekphrasis, not apostrophe).

${ }^{183}$ The term 'High Style' is Christopher Page's. See Page, Voices and Instruments of the Middle Ages: Instrumental Practice and Songs in France, 1100-1300 (Berkeley and Los Angeles, 1986), pp. 10-17. Such semantic contrasts are principle among the poetic devices studied by S. Huot, Allegorical Play in the Old French Motet. 
Sean Curran, 'Hockets Broken and Integrated in Early Mensural Theory and an Early Motet', Early Music History vol. 36 (2017); author's revised manuscript, accepted 4 May 2017.

challenge laid down by motets that, as Emma Dillon has so elegantly revealed, veil prayer texts in the 'supermusical' effect of polytextuality so as both to tempt the mind to wander, and to increase the value of contemplation when concentration on the prayer is sustained. ${ }^{184}$ So, let us now choose to follow this other path, and pursue the argument each part constructs from its musical matter, beginning with the motetus.

The motetus's vocal failure is still more terrible a breakdown for the way it is prepared over a longer range - something which can be detected when we consider how the musical phraseology and figuration handle the verse units. To make those relations clearer to the eye, example 4 presents an analytical transcription of the motetus. Musical lines are divided wherever there is a notated rest in the part, the resulting phrases given Roman numerals at the left margin. ${ }^{185}$ Beneath them, verse

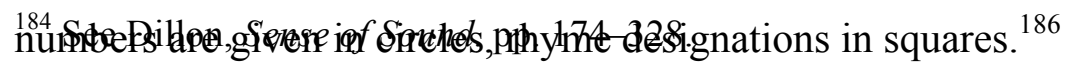

${ }^{185}$ Everist conducts paradigm analysis to show internal repetitions in thirteenth-century motets (French Motets in the Thirteenth Century, e.g. pp. 168-69); Clark uses a similar method to reveal a hidden 'stanza' shape in a motet part ("“S'en dirai chançonete," p. 51); and Zayaruznaya disposes small-format scores of fourteenth-century motets on the page so as to make visible their isorhythmic regions (e.g. The Monstrous New Art, p. 88). My diagrams are modelled on theirs. My account of the song-representations in the piece also builds on J. A. Peraino's claim that refrains may be synechdoches for - rather than citations of - longer songs; see Peraino, “"Et pui conmencha a canter”, 2-4. Examples 4 and 5 report as apostrophes above the score short strokes used by the scribe to indicate phrase divisions not articulated by silences.

${ }^{186}$ Again the analysis holds across the manuscript witnesses, as only three variants divide phrases by silence differently than does Mo. (1) Motetus b. 12: MuA has $b[\mathrm{~B}]+\operatorname{rest}[\mathrm{L}]$, dividing verses 3 and 4 (articulating with silence what Mo acknowledges as a phrase-break 
Sean Curran, 'Hockets Broken and Integrated in Early Mensural Theory and an Early Motet', Early Music History vol. 36 (2017); author's revised manuscript, accepted 4 May 2017.

\section{[EXAMPLE 4 NEAR HERE]}

Our poet-composer knows the devices that a trouvère might use to give shape to his song in time, and uses them to set up a representational gambit: the narrator is trying to sing a stanza of ten verses, but he cannot keep his vocal composure. ${ }^{187}$ The stanza's constituent components, eminently plausible in the vernacular lyric repertory, are marked with vertical square brackets, and demarcate first by rhyme and musical phrase: a quatrain rhyming aaab, and two tercets rhyming bbc and ddc. ${ }^{188}$ They are

with a short stroke); all other sources agree with Mo. (2) Triplum b. 17: Cl has $g^{\prime}[\mathrm{B}]+$ rest[L], dividing verses 5 and 6 . Compatibly with my argument, Cl's reading makes second aabarhymed segment of the emerging song form more palpable, setting all its verses to phrases of 3P. (3) Triplum b. 28: $\mathrm{Cl}$ transmits rhythmic errors, among them a rest; the reading can be disregarded.

187 Gaël Saint-Cricq identifies 18 motets that strictly reproduce the AAB melodic-repetition scheme characteristic of trouvère chansons. See Saint-Cricq, 'A New Link Between the Motet and Trouvère Chanson: The Pedes-cum-cauda Motet', Early Music History, 32 (2013), pp. 179-223. In his wonderful $\mathrm{PhD}$ dissertation, he included Dame vostre douz regart in a further list of 24 'péri AAX' motets whose repetition scheme is less strict. See Saint-Cricq, 'Formes Types dans le Motet du XIII ${ }^{\mathrm{e}}$ Siècle: Étude d'un Processus Répétitif', 2 vols. (PhD diss., University of Southampton, 2009), URL: http://eprints.soton.ac.uk/id/eprint/203381, at ii, pp. 8-9, where this motet is no. XVI. Saint-Cricq's AA' section corresponds to my segment 1 ; but though we both highlight other repetitions in the rest of the piece, we interpret its sectionalisation differently.

${ }^{188}$ A quick search in the standard index of Old French lyrics (G. Raynaud, rev. Hans Spanke, G. Raynauds Bibliographie des alfranzösischen Liedes [Leiden, 1955], henceforth 'RaynaudSpanke'), found 89 lyrics using the rhyme scheme aaab to demarcate a segment of the poem: nos. 1, 10a, 11, 47a, 50, 51, 54, 56, 57, 67, 102, 105, 122a 141, 144, 165, 278, 317, 339, 355a, 
Sean Curran, 'Hockets Broken and Integrated in Early Mensural Theory and an Early Motet', Early Music History vol. 36 (2017); author's revised manuscript, accepted 4 May 2017.

made shapely by other parameters of musical design too. Thus the quatrain of verses 1 through 4 is handled melodically as two pairs of verses, each pair set to one phrase. Phrase I sets up an open/closed pitch structure contrasting $b$ with $c$ ' as the goals of verses 1 and 2, while phrase II (verse 3) repeats the pitches from the opening of phrase I. Phrases IV through VI set the first tercet: it is organized by phrase length, by the metrically parallel use of transposed figure-repetitions (shaded in example 4), and concluded by the open-closed relationship of phrases V and VI. The final tercet of verses 12 through 14, all set in phrase $\mathrm{X}$, is especially nimble. The composer prepares the fractio figure $y$ that will be heard at the end of verse 13 (the first verse of the refrain) by using it at the end of verse 12 too, thus making palpably audible the tercet's ddc rhyme structure.

Now the interruptions. Things start to go awry near the end of phrase II: hitting $c$ ' on the penultimate perfection, the narrator overshoots the tonal mark, finishing the phrase at $e^{\prime}$ with the motion $c^{\prime}-d^{\prime}-e^{\prime}$. It is as if worry were showing in his voice, through the song he sings. ${ }^{189}$ At phrase III the worry causes an outburst: $386,413,413,436,461,475,532,577,611 \mathrm{a}, 764,766,795,799,811,835 \mathrm{a}, 868,835,835 \mathrm{a}$, 868, 871a, 878a, 897, 901, 910a, 935, 966, 969, 1013, 1048, 1077, 1101, 1160, 1177, 1197, $1259,1323,1347,1359,1360,1362,1376,1385 \mathrm{a}, 1405,1406,1407,1481,1524,1602,1604$ 1646, 1701, 1735, 1750, 1781, 1805, 1808, 1828, 1862, 1898, 1902, 1915, 1924a, 1996, 2009, 2017a, 2043, 2048, 2087, 2103. Perhaps others evaded detection; but this many suffices to show that the scheme was known and relatively common. The rhyme-scheme aab (or xxy) for tercets is ubiquitous, and does not require listing here.

${ }^{189}$ Clark finds a depiction of a singer's vocal style in "“S'en dirai chançonete," at p. 39. See also Carolyn Abbate's discussion of Wotan's authorial singing voice, in 'Wotan's Monologue and the Morality of Musical Narration', in Unsung Voices Opera and Musical Narrative in 
Sean Curran, 'Hockets Broken and Integrated in Early Mensural Theory and an Early Motet', Early Music History vol. 36 (2017); author's revised manuscript, accepted 4 May 2017.

'May it not be too late!' he cries out high - in a comic touch, using a fractio motive $g^{\prime} a^{\prime} b^{\prime} a$ ' $[\mathrm{BSSB}]$ that the triplum sang only one perfection earlier. He recovers his nerve long enough to sing the second tercet. But in phrase VII, just as he starts to explain why he is so upset, the melody tells us he is crying out again, for it repeats the distressed phrase III exactly. So when the hocket comes in phrase VIII, it interrupts an interruption, and is framed by a progressive logic that breaks a song apart along its fault-lines.

Something snaps the narrator out of it in time to bring off his last tercet; we may well wonder what. More about that shortly. In the meantime, notice that, just as nimbly, the piece comes to a close with a decorated version of the $c^{\prime}-d^{\prime}-e$ ' tag (we can think it a transposition of $x$ ) that finished phrase II. Under the representational conditions set up earlier, the tag showed the narrator's voice wandering off the song's path. When it appears at the end, it rhymes the end of the opening quatrain with the end of the piece. It is as if the composer has changed the map adaptively, and found for his song a suitable close in spite of its singer. ${ }^{190}$ The song's shapeliness is recuperated, but only at the last, and by cunning.

the Nineteenth Century (Princeton Studies in Opera 4; Princeton: Princeton University Press, 1991), pp. 156-205.

${ }^{190}$ The classic study of compositional agency is E. T. Cone, The Composer's Voice (Berkeley and Los Angeles, 1974). The unveiling of authorial agency is a topos widespread in medieval musical and literary forms, and has generated a rich (and developing) scholarship. Among studies formative to my thinking here, see K. Brownlee, Poetic Identity in Guillaume de Machaut (Madison, WI, 1984); E. E. Leach, 'Death of a Lover and the Birth of the Polyphonic Ballade: Machaut's Notated Ballades 1-5', Journal of Musicology, 19 (2002), pp. 461-502; E. E. Leach, 'Nature’s Forge and Mechanical Production: Writing, Reading, and Performing Song', in M. Carruthers (ed.), Rhetoric Beyond Words, pp. 72-95; A. Stone, 'The 
Sean Curran, 'Hockets Broken and Integrated in Early Mensural Theory and an Early Motet', Early Music History vol. 36 (2017); author's revised manuscript, accepted 4 May 2017.

At least, when one considers the motetus alone. In fact, composerly skill is announced earlier, by a collaboration of the voices. Let us now look at the triplum's poem (see the text and translation in appendix 1). In its lexicon of topoi, it is akin to the motetus, and, as we know, it is also about the Lady and her look. The first nine verses describe her, adding bodily and emotive features paratactically and at such length as to draw attention to themselves as an ekphrasis. With the verb in verse 10 , the descriptive spell seems to end: the Lady has 'wounded' the narrator's heart: 'Powerless, what can it do?' he laments: 'Thus I cry when I feel this: “Beautiful sweet sweetheart, loyally, heart, body and life I render entirely to you!'” He might seem as powerless as the motetus. But the design of the triplum he sings is very different indeed from that of the other texted part: this narrator's music tells us he is not as helpless as he seems. In fact, he is a skilled song-maker, and a protean one, capable not just of building forms, but transforming them.

\section{[EXAMPLE 5 NEAR HERE]}

Example 5 is an analytical transcription of the triplum, once again setting it out according to its musical phrases, dividing lines wherever there is a notated rest. Three little song-segments are projected by the voice-part (marked on the diagram with vertical brackets to their right). The third and most substantial (comprising phrases VI through X) leaps off the page, each of its phrases lasting five perfections and setting two verses. Significantly, the first note of segment 3 begins on the final

Composer's Voice in the Late-Medieval Song: Four Case Studies', in Philippe Vendrix (ed.), Johannes Ciconia: Musicien de la transition (Turnhout, 2003), pp. 169-94; and A. Stone, 'Self-Reflexive Songs and Their Readers in the Late 14th Century', Early Music, 31 (2003), pp. $180-94$. 
Sean Curran, 'Hockets Broken and Integrated in Early Mensural Theory and an Early Motet', Early Music History vol. 36 (2017); author's revised manuscript, accepted 4 May 2017.

note of the tenor's first cursus (b. $24^{1}$ ): the most important formal junctures in each part are aligned across the texture in the manner of a dovetail join.

The relation of the first two, smaller segments is subtler. Both are quatrains demarcated by the rhyme structure aaba; but they dovetail too, so that the last verse of segment one (which comprises verses 1-4) is also the first verse of segment two (47). ${ }^{191}$ Again, other parameters of melodic design create patterns within each segment. Thus in segment 1, phrases I and II (each setting a single verse) are marked as a couplet through parallel figuration derived from the refrain (shaded in the example); and the long phrase III answers them, setting the couplet of verses 3 and 4, and marking it further with a repetition from phrase I of the motetus. Segment 2 has a very similar shape: verses 4 and 5 have rhyming cadence figures (see the dashed boxes in the diagram), to which verses 6 and 7 serve as an answering couplet projected through the symmetrical use of refrain-derived motives.

Thus the singer can build forms. But the dovetailing signals that he can transform them too, for he inaugurates the second segment by reinterpreting the final cadence of the first as the start of a new pattern, as if morphing one unit into the next. Wittily, this is done with the same $a^{\prime}-b^{\prime}-a^{\prime}$ melodic tag with which the motetus will cry out in despair and to disruptive effect: the intersonic echo between the parts

\footnotetext{
${ }^{191}$ Another quick search through Raynaud-Spanke found that the rhyme scheme aaba demarcated a set of four verses in 25 lyrics: $120,315,631,689,722,892,985,987,1095$, 1123, 1196, 1203, 1216, 1226, 1275, 1290, 1325, 1574, 1620, 1634, 1745, 1793, 2066, 2111 , 757. A further 24 songs showed a segment with the same contrast pattern, but using subsequent rhymes (thus xxyx): 43, 135a, 142, 587, 1054a, 1096, 1170, 1271, 1296, 1317 , 1356, 1374, 1476, 1540, 1547, 1589, 1668, 1669a, 1684, 1911, 1945, 1954, 2067, 2106.
} 
Sean Curran, 'Hockets Broken and Integrated in Early Mensural Theory and an Early Motet', Early Music History vol. 36 (2017); author's revised manuscript, accepted 4 May 2017.

directly contrasts the form-building prowess of one singer with the poor composure of the other.

From a formal perspective, the third segment is the triplum's most shapely; yet, in apparent contradiction with triplum's textual narrative, its second phrase (phrase VII, with the words 'a mon cuer navré') is where the narrator starts to speak of his wounding, his helpless undoing by love. But his claim is a red herring. In another dovetailing, the ekphrastic mode continues, passing from an imagistic to a formal kind of description, as structural properties of the refrain are added in three steps. Phrase VI describes the refrain's phrase-length; phrase VII uses the refrain's calling-card opening motif $x$ to intimate what will come; and phrase VIII establishes its syllable count and rhyme (see the annotations in example 5). By now, all its other formal parameters are there; all that remains is for the refrain to sound with its melody, as if to fill a formed body with spirit at the powerful narrator's command. No possessive adjectives qualify the heart, body, and life the narrator gives: he is giving $a$ heart, $a$ body, $a$ life, but they are not his own. As the refrain is heard, the music reveals the answer to the poetry's question. What can one do in the face of such feeling? One can compose. ${ }^{192}$ The triplum's narrator is a musical Pygmalion, and step by step, he has rendered the lady as a song. ${ }^{193}$

\footnotetext{
${ }^{192}$ The interplay of love- and song-making is a central topos in the troubadour canso or the trouvère chanson. See Peraino, Giving Voice to Love, p. 3-32 and pp. 123-85, and the literature cited there.

${ }^{193}$ The Pygmalion intertext is Ovid, Metamorphoses 10.243-97. The Metamorphoses were well known to scholars of the twelfth and thirteenth centuries. See F. T. Coulson, 'Ovid's Metamorphoses in the School Tradition of France, 1180-1400: Texts, Manuscript Traditions, Manuscript Settings', in J. G. Clark, F. T. Coulson, and K. L. McKinley (eds.), Ovid in the
} 
Sean Curran, 'Hockets Broken and Integrated in Early Mensural Theory and an Early Motet', Early Music History vol. 36 (2017); author's revised manuscript, accepted 4 May 2017.

\section{[EXAMPLE 8 NEAR HERE]}

There is a final twist. The narrator attains the height of his form-building power in phrase VIII; and it is that very moment when the motetus shatters into (carefully prepared) formlessness. The interpretative dilation is knowing, marked by a collaboration of the voices at b. 34, which invert each other's fifth in contrary motion, $a^{\prime}-d^{\prime}$ in the motetus, $d^{\prime}-a^{\prime}$ in the triplum. (See example 6.) The effect is to amplify the motetus's hocket by drawing on the fund of stylistic devices that often also accompanied sudden silence in a single part. Those who want pitch repetition and voice-exchange with their hockets will be satisfied. For a moment, the two developing formal logics reach maximum rupture and maximum logic, all at once. It is just then that the parts take stock of one another. That is what the hocket marks, in a bravura flourish of its dual character. If he heard the piece, and understood it, St Emmeram would have been thrilled.

\section{Hearing the Hocket's Dual Character}

Middle Ages (Cambridge, 2011), pp. 48-82. For a recent critical account of the Pygmalion episode in Old French literary texts, see M. Griffin, Transforming Tales: Rewriting Metamorphosis in Medieval French Literature (Oxford, 2015), pp. 167-72. Griffin observes that 'what is at stake in this metamorphosis of statue into woman is the relationship between nature and art' (ibid., 167). This insight captures something important about our triplum too. But where Pygmalion's statue was a material thing wondrously turned to flesh, art transformed into life, the fictional gambit of our triplum works the other way around: albeit that the refrain takes final flight, nevertheless the represented song it caps is an artistic thing wrought from lived experience; it transforms life into art. 
Sean Curran, 'Hockets Broken and Integrated in Early Mensural Theory and an Early Motet', Early Music History vol. 36 (2017); author's revised manuscript, accepted 4 May 2017.

I suggest, then, that our composer also knew the hocket's dual character - its balance of broken sound and integrative planning - and turned to it as a creative resource. In so doing, the hocket was made to say something about the motet; and, complementarily, the motet says something about hockets. There are several reasons why this is important, and we should consider them before ending.

First, the chronology of the motet's sources is such that this creative flourish of dual character was probably composed before the hocket was subject to the rationalized processing of the theorists, and certainly long before St Emmeram's brilliantly idiosyncratic account - perhaps by as many as thirty or even forty years. ${ }^{194}$ What becomes formalized in later theory, I suggest, seems to have begun in musicopoetic exploration. As composers explored what words went well with hockets - and, more generally, with the measured music in the styles originating in the Parisian organa - their opportunities were not only technical ('What sort of rhyme patterns can I build with phrases like these?' or, 'How can I match this Latin versification scheme with a new one in French?' and so on); they were also semantic ('To what ideas, pictures, affects, or actions can this musical device lend itself?' or, 'What musical device will work well with this idea?'). We have suspected for some time that theorists and scribes of the middle and late thirteenth century played their part in archiving, shaping, and repackaging the styles of music heard around 1200CE at Notre Dame, and that the music was transformed as well as transmitted by their

\footnotetext{
${ }^{194}$ For an overview of positions on the major early sources, see Roesner, ed., Les Quadrupla et tripla de Paris, pp. 1xx-1xxxi. The touchstone for all work on Ars Antiqua manuscripts is Everist, Polyphonic Music in Thirteenth-Century France: Aspects of Sources and Distribution (Outstanding Dissertations in Music from British Universities; New York, 1989).
} 
Sean Curran, 'Hockets Broken and Integrated in Early Mensural Theory and an Early Motet', Early Music History vol. 36 (2017); author's revised manuscript, accepted 4 May 2017.

mediation. ${ }^{195}$ The case of our motet suggests that to play with texts, and with their delineation in notes, was for poet-composers a similarly mediating activity, which could shape the understanding of the musical styles and pre-existing materials with which they worked. Their musicopoetic work was 'theoretical' too, in this more expansive and pragmatic conception of the term; ${ }^{196}$ and doubtless it would have been part of a feedback loop with new composition. From that perspective, the mensural treatises of the later century would be works of criticism as well as of theory; for perhaps St Emmeram's insight about the hocket was inspired by pieces like Dame vostre douz regart.

Hockets often serve to point out moments of formal significance in the motet of the fourteenth century. Anna Zayaruznaya has treated several such pieces in her recent study, finding the hocket important among devices for making audible the seams and junctures of the units that build a motet's form. ${ }^{197}$ The hocket in our motet, too, occurs at an important moment of design - and indeed, one not to do with the tenor structure, but (as in the cases that most interest Zayaruznaya ${ }^{198}$ ) with the structures of the upper parts. Thus it reminds us of deeper thirteenth-century roots to

${ }^{195}$ E. H. Roesner, 'The Problem of Chronology in the Transmission of Organum Duplum', in Iain Fenlon (ed.), Music in Medieval and Early Modern Europe: Patronage, Sources, and Texts (Cambridge, 1981), pp. 365-99; and Roesner, 'Who "Mad"' the "Magnus Liber"?' Early Music History, 20 (2001): pp. 227-66, and Rankin, 'The Study of Medieval Music'. ${ }^{196}$ I am influenced here by Johnson, Practicing Literary Theory, who analyses moments in which Middle English texts 'step outside of themselves, to do the work of theoretical commentary and to enact meditations on the nature of literary experience itself' (ibid. p. 11). ${ }^{197}$ Zayaruznaya, The Monstrous New Art, pp. 220-21 and passim.

${ }^{198}$ Ibid., p. 10, and passim. 
Sean Curran, 'Hockets Broken and Integrated in Early Mensural Theory and an Early Motet', Early Music History vol. 36 (2017); author's revised manuscript, accepted 4 May 2017.

its later function. ${ }^{199}$ But how to characterize the hocket's role here? 'Formal' seems not quite right, given prevalent notions of musical form that entail repetition. This hocket is not in itself repeated; and the collaborative work across the parts that augments it does not seem to cut the motet as a whole into an uneven bipartite 'shape' (though it does serve to mark off, and thus perhaps to draw attention to, the citation of the refrains). Rather, it occurs in a moment of reciprocity at which the parts arrive as, each following its own course, their individual patterns emerge and change in time. ${ }^{200}$ For this fleeting passage, the varied parts conspire to reveal a unity of purpose before going on their own ways again, inviting a 'monaural' listening stance. ${ }^{201}$ The moment

${ }^{199}$ Hoppin's textbook said something wise about this: 'As a rule, longer hocket passages are reserved for melismatic polyphony; passages with text are usually short and introduce a momentary contrast to the normal motet style. In neither case, however, is hocket introduced to no purpose, although that purpose may sometimes be difficult to determine. Some hocket passages are exclamatory or descriptive; others function as structural elements by underlining the organization of the tenor, a use of hocket that becomes increasingly important in the fourteenth century'. (Medieval Music, p. 345.) The assumption that the tenor's structure is necessarily most important bears the marks of older thought; but everything else here is quite right.

${ }^{200}$ Again, a formulation inspired by M. Carruthers, 'The Concept of Ductus'.

${ }^{201}$ I develop this notion of 'monaurality' in the thirteenth-century motet in S. Curran, 'Writing, Performance, and Devotion in the Thirteenth-Century Motet: The 'La Clayette' Manuscript', in H. Deeming and E. E. Leach (eds.), Manuscripts and Medieval Song: Inscription, Performance, Context (Cambridge, 2015), 193-220; at 217. The adjective 'monaural' complements 'polytextual', and characterises the effect when a motet's many listening stances coalesce into a single one, revealing for a moment a unitariness of 
Sean Curran, 'Hockets Broken and Integrated in Early Mensural Theory and an Early Motet', Early Music History vol. 36 (2017); author's revised manuscript, accepted 4 May 2017.

reveals that the voices have been purposive all along, a sign that they have indeed been formed. ${ }^{202}$

We arrive at the inevitable question: can the hocket's significance be heard, or only known? Substitute the word 'motet' for 'hocket' in that formulation, and the question sums up the motivating concern of very much productive scholarship in the last thirty years. I suggest that what we have heard as a historiographical problem was for our composer another creative opportunity: that his motet asks precisely the questions about the audibility of form and of meaning that we have asked, and does so with its hocket passage. Perhaps the most salient property of the passage (bb. 34-38) is the sudden reduction to an unadorned dyadic texture, the three parts contrived to yield the effect of two by staggering phrases and doubling pitches; set off from what has come before by the motet's only silence shared by all parts, it bears the hallmarks of sonic transparency. But its sense is opaque unless prepared by a herculean effort of will to sustain the operation of reason (a difficulty germane to hockets and intensified by polytextuality), ${ }^{203}$ as the ear battles against perceptual odds to follow the designs

interpretative purpose before the parts go on their own ways again. For a different use of the word, see C. Abbate, Unsung Voices, pp. 63-64 and 69.

${ }^{202}$ This recalls T. W. Adorno's notion of form as 'everything on which the hand has left its trace, everything over which it has passed'. See Adorno, Aesthetic Theory, ed. G. Adorno and R. Tiedeman, trans. R. Hullot-Kentor (Theory and History of Literature, 88; Minneapolis, MN, 1997), p. 143.

${ }^{203}$ Again, see Leach, Sung Birds, pp. 11-54 and passim. My wording recalls Steven Justice's account of the cognitive work of medieval belief. See Justice, 'Did the Middle Ages Believe in Their Miracles?' p. 14. 
Sean Curran, 'Hockets Broken and Integrated in Early Mensural Theory and an Early Motet', Early Music History vol. 36 (2017); author's revised manuscript, accepted 4 May 2017.

of both texted parts taking shape through the cloud of intersonic echoes. ${ }^{204}$ This duality of clarity and staggering difficulty, too, is surely contrived. If such a hearing is possible - and perhaps it is not - one would have to listen with the willing ears of a St Emmeram - and perhaps that is the point. ${ }^{205}$

All this, of course, is another apt response to the scene of disambiguation referenced by the tenor's chant, where erroneous listening is also corrected. In this sense, too, listening hard to the hocket leads the mind back to the fundamentum of its tenor.

Thus our motet composer knows an opinion about the ethics of listening with active attention that anticipates St Emmeram's. The motet, meanwhile, would seem to anticipate some recent thinking on the value of being present to artistic experience, to its liveness and ephemerality - work stimulated by Carolyn Abbate's stirring invitation to a (scholarly, listening, ethical) practice 'that at its most radical allows an actual live performance (and not a recording, even of a live performance) to become an object of absorption' ${ }^{206}$ In Abbate's account, listening for a piece's formal features represents an intrusion of a 'gnostic' attitude into a time over which the

\footnotetext{
${ }^{204}$ This, notwithstanding that preparation outside the real-time of performance must have been practiced by some. On which, see Bent, 'Polyphony of Texts and Music', p. 82.

${ }^{205}$ Thus I arrive via a different path on ground covered by Emma Dillon's beautiful study of the ethics of attention in thirteenth-century prayer practice and their manifestation in the polytextual motet: see Dillon, The Sense of Sound, pp. 174-328.

${ }^{206}$ See C. Abbate, 'Music—Drastic or Gnostic?' Critical Inquiry, 30 (2004), pp. 505-536, at p. 506 .
} 
Sean Curran, 'Hockets Broken and Integrated in Early Mensural Theory and an Early Motet', Early Music History vol. 36 (2017); author's revised manuscript, accepted 4 May 2017.

'drastic' better presides. ${ }^{207}$ My account of Dame de valour (71) / Dame vostre douz regart (72) / MANERE (M5) is offered as a grateful acknowledgment of that work from another wing of the discipline. It is also offered as another quiet reminder that debates about the relative roles of the intellect and the sensorium in correct and ethical musical perception have a very deep historical lineage indeed, far deeper even than the thirteenth century of the common era. ${ }^{208}$ More, active cognitive labor and affective openness to the ephemeral are complementary in our motet's casting, not in contest. And if we are to give its ideas their historical due, we must inevitably engage with notated texts, and largely in the absence of the music's sonic force. For thirteenth-century motets (among many other medieval and early-modern genres) are

${ }^{207}$ Abbate, 'Music —Drastic or Gnostic?' 511 and 530-31. Abbate builds on V. Jankélévitch, Music and the Ineffable, trans. C. Abbate (Princeton, NJ, 2003). See also H. U. Gumbrecht, Production of Presence: What Meaning Cannot Convey (Stanford, CA, 2004).

${ }^{208}$ Other reminders include K. Berger, 'Musicology According to Don Giovanni, Or: Should We Get Drastic?' The Journal of Musicology, 22 (2005), pp. 490-501, at p. 495 and p. 497 (respectively on Horace and St Augustine); Dillon, The Sense of Sound, pp. 174-328; and Leach, Sung Birds, pp. 11-54. Abbate acknowledges a deeper historical legacy when, paraphrasing Jankélévitch, she writes, 'Embarrassing reversions may be necessary, to Neoplatonic philosophy, for instance, or its stepchild, apophatic theology.' ('Music—Drastic or Gnostic?' pp. 529-30; referencing Jankélévitch, Music and the Ineffable, pp. 111-19, and pp. 130-55); the medieval also makes an appearance in Abbate's article at p. 531 n.58. But insofar as they are characterized as justifying a non-intellective rapture before the unspeakable, this conception of premodern philosophy and theology does not match the very agitative cognition explored by the scholastic Anonymous of St Emmeram, and by our motet. 
Sean Curran, 'Hockets Broken and Integrated in Early Mensural Theory and an Early Motet', Early Music History vol. 36 (2017); author's revised manuscript, accepted 4 May 2017.

seldom performed, and who knows whether our modern experiments approximate medieval sounds? $?^{209}$

To be quite clear: this is an historiographical intervention, not a philosophical one; I am giving no sermon. To point out that the motet voices a position on musical ethics is not to endorse that position. Indeed, neither need all listeners of the thirteenth century have endorsed it. Whether or to what extent the motet's advocated brand of close listening has facts of social history on its side is hardly clear. ${ }^{210}$ We are far from certain knowledge about social settings, uses, and listening practices for this music, although the surest sign that they were manifold is the variety of kinds of manuscript into which they were copied. ${ }^{211}$ There were, and remain, many ways to hear the motet.

So though I do not agree with St Emmeram that it will make me (or anyone else) a better person to listen so laboriously, I do enjoy the way our motet's narrators

${ }^{209}$ See Bent, 'The Grammar of Early Music'; and Bent, 'Grammar and Rhetoric in Late Medieval Polyphony: Modern Metaphor or Old Simile?' in M. Carruthers (ed.), Rhetoric beyond Words, pp. 52-71.

${ }^{210}$ The motet is still often considered a pre-eminently clerical genre, though that is changing. For a predominantly clerical view (though one alert to how broad a socio-economic sweep of men entered orders, and how wide was the range of literary registers the motet engaged), see Page, Discarding Images. For recent explorations of possible extra-institutional milieux, see S. Curran, 'Composing a Codex: The Motets in the 'La Clayette' Manuscript', in J. A. Peraino (ed.), Medieval Music in Practice: Studies in Honor of Richard Crocker, (Miscellanea 8; Middleton, WI, 2013), pp. 219-253; and Curran, 'Reading and Rhythm in the 'La Clayette' Manuscript (Paris, Bibliothèque Nationale de France, nouv. acq. fr. 13521)', Plainsong and Medieval Music, 23 (2014), pp. 125-151.

${ }^{211}$ See Curran, 'Writing, Performance, and Devotion'. 
Sean Curran, 'Hockets Broken and Integrated in Early Mensural Theory and an Early Motet', Early Music History vol. 36 (2017); author's revised manuscript, accepted 4 May 2017.

make their point, and so, I will give them the final word. They would accord with St Emmeram's opinion, for theirs is a story about listening and transformation too - one not necessarily unserious for being short and told in a playful manner. At b. 34, the upper parts invert one another's pitches, using the widest melodic interval (a fifth) heard in either part. However, the two $a^{\prime} / d^{\prime}$ ' dyads that sound cannot have been alike in quality, for they result from quite opposed scripts for vocal action. ${ }^{212}$ As the motetus traces an anguished sigh that falls off into nothing, not knowing how he can go on, the triplum rises to the heights with hortatory force to suggest a course of action. At last the narrators hear one another with understanding, and the effect is wondrous. In b. 35, while the motetus listens on, the triplum sings just this one time the version of motif $y$ from which the motetus's refrain will be formed. ${ }^{213}$ Picking him up from despair, the triplum teaches his friend how to correct his folly, and finish his song. Inspired and brave, the motetus steadies his voice, and embarks on his final tercet. $^{214}$

${ }^{212}$ On motet parts that script a singer's physical labor to affective ends, see Curran, 'Writing, Performance, and Devotion', pp. 208-220; and Curran, 'Feeling the Polemic of an Early Motet', in A. Suerbaum, G. Southcombe, and B. Thompson (eds.), Polemic: Language as Violence in Medieval and Early Modern Discourse (Farnham, and Burlington, VT, 2015), pp. 65-94, at pp. $75-77$.

${ }^{213}$ I have not suggested $b^{\prime} b$ in the motetus at b. 35, albeit that the tenor sounds $f^{\prime}$ against the first, in order to preserve the cadential rhyme with b. 40 where the tenor has $b$ Ł. Dissonances with the tenor were evidently accepted to project a musical citation with clarity: hence the motetus's $e^{\prime}$ at b. 41 (echoed at b. 45) against tenor $d^{\prime}$.

${ }^{214}$ Like our motet, this article ends with a double allusion. Elaine Scarry argues that being struck by beauty alerts one to errors of care and attention, and enjoins that they be corrected; the experience can prepare one for moral action. See E. Scarry, On Beauty and Being Just 
Sean Curran, 'Hockets Broken and Integrated in Early Mensural Theory and an Early Motet', Early Music History vol. 36 (2017); author's revised manuscript, accepted 4 May 2017.

\section{Appendix 1}

Motet, Dame de valour (71) / Dame vostre douz regart (72) / MANERE (M5).

The motet has been transcribed and its texts translated afresh. Previous editions include: Rosketh, Polyphonies du XIII siècle, 2:183-85 (which, barred in 3/8, most closely matches my own); Anderson, ed., with Close, Motets of the Manuscript La Clayette, 41-42; Tischler, ed., The Montpellier Codex, part II, Fascicles 3, 4, and 5, 91-92; Tischler, ed., The Earliest Motets (to circa 1270), ii, pp. 957-62. A further edition and translation of the texts is Smith, French Double and Triple Motets, 13536. For their comments on my translation of the French text, I am grateful to Irène Fabry-Tehranchi and Jane Gilbert. Any outstanding errors are my own.

Here as throughout, a long of three tempora is transcribed with a dotted crotchet; a long of two tempora and the brevis altera with a crotchet. Semibreves are transcribed with equal quavers, either as a tuplet (when two semibreves divide a breve) or triplet (when three do so). Accidentals have been suggested in order to perfect diminished fifths or augmented fourths between the tenor and an upper part, though not when such intervals appear between the upper voices. I suggest accidentals sparingly, because it seems likely that the different accidentals reported across the sources stem from changing conceptions of the motet's counterpoint over the course of the thirteenth century; ${ }^{215}$ tampering with them in this transcription (especially when my

(London, 2006), esp. pp. 12-33. Our motet makes a similar point, some eight centuries earlier. The blend of vocal fracture and bravery alludes, of course, to Carolyn Abbate's witness to Ben Heppner's loss of voice in C. Abbate, 'Music—Drastic or Gnostic?' p. 535.

${ }^{215}$ A matter commented on by Edward H. Roesner in Roesner ed., Les Quadrupla et tripla de Paris, xci. On the grammar of fourteenth-century counterpoint, see Bent, Counterpoint, 
Sean Curran, 'Hockets Broken and Integrated in Early Mensural Theory and an Early Motet', Early Music History vol. 36 (2017); author's revised manuscript, accepted 4 May 2017.

analysis is largely unconcerned with matters of discant or counterpoint) might obscure rather than clarify historically revealing details.

\section{APPENDIX 1 page 1 and APPENDIX 1 PAGE 2 NEAR HERE, Facing one another}

\section{on a single opening.}

Texts:

NB. Although unaccented terminal -e may not have been sounded in spoken Old French, it is handled as a syllable (when not elided with a following vowel) by composers, its pitches written with their own figure by scribes. Thus I include it in my syllable counts, even though editorial convention for Old French texts would usually omit it, because it sheds more light on the texts' musical shaping. E.g. I count verse 13 of Dame vostre doz regart as 8 syllables, rather than notating it $7^{\prime}$.

\begin{tabular}{lll} 
Dame de valour, & $5 \mathrm{a}$ & [A] Lady of valour, \\
Regart plain d'amour, & $5 \mathrm{a}$ & Look full of love, \\
Promesse de loiauté, & $7 \mathrm{~b}$ & Promise of loyalty, \\
[Cuer] plesant, plein de douçor, & $7 \mathrm{a}$ & Pleasant heart, full of sweetness, \\
Cors simple d'ator & $5 \mathrm{a}$ & Body simply attired, \\
Et de grant biauté, & $5 \mathrm{~b}$ & And of great beauty, \\
Fresche de coulor, & $5 \mathrm{a}$ & Fresh in colour, \\
Oevre d'amistié & $5 \mathrm{~b}$ & Act of friendship \\
Sans folour & $3 \mathrm{a}$ & Without imprudence \\
A mon cuer navré; & $5 \mathrm{~b}$ & Has wounded my heart; \\
Et sans [poour] & $4 \mathrm{a}$ & And, powerless, \\
Qu'en puet il? Si crie & $6 \mathrm{c}$ & What can it do? Thus I cry \\
Quant ce sent: & $3 \mathrm{~d}$ & When I feel this: \\
Bele, douce amie, & $6 \mathrm{c}$ & Beautiful, sweet sweetheart, \\
\multicolumn{1}{c}{ loiaument } & $3 \mathrm{~d}$ & Loyally \\
Cuer et cors et vie & $6 \mathrm{c}$ & Heart and body and life \\
\multicolumn{1}{c}{ tot voz rent. } & $3 \mathrm{~d}$ & I render entirely to you.
\end{tabular}

Motetus:

Dame, vostre doz regart $\quad 7 \mathrm{a} \quad$ Lady, your tender look

M'ocit quant de voz me part; $7 \mathrm{a} \quad$ Kills me when I take leave from you;

Ne ie, certes, cele part $\quad 7 \mathrm{a} \quad$ Neither, for sure,

Composition, and Musica Ficta; and Bent, 'The Grammar of Early Music' (among several of her publications). 
Sean Curran, 'Hockets Broken and Integrated in Early Mensural Theory and an Early Motet', Early Music History vol. 36 (2017); author's revised manuscript, accepted 4 May 2017.

Ne me puis torner;

5. Qu'il ne me soit tart, Qu'a vous puisse retorner! Car sans voz ne puis durer, Ne bien avoir longuement, Quant ne puis souvent

10. Aler,

Parler

A vous, a ma devise.

Li maus d'amer me debrise, Et la [douleur que je sent.]
$5 b$

5

$7 \mathrm{~b}$

Can I turn myself back in that direction.

Let it not be too late

$7 \mathrm{~b}$

For me to be able to return to you!

$7 \mathrm{~b}$

For without you I cannot go on living,

7c Nor be well for very long,

$5 \mathrm{c} \quad$ When I cannot often

2b Go,

$2 b \quad$ Speak

$7 \mathrm{~d} \quad$ To you at my liking.

$8 \mathrm{~d} \quad$ The pain of love is breaking me,

7c And the pain that I feel.

Tenor:

MANERE:

To remain 
Sean Curran, 'Hockets Broken and Integrated in Early Mensural Theory and an Early Motet', Early Music History vol. 36 (2017); author's revised manuscript, accepted 4 May 2017.

Appendix 2. A handlist of Ars Antiqua motet texts containing hockets.

This handlist comprises all motet texts with hockets that I have found in the major manuscript collections of thirteenth-century motets indexed in van der Werf, Integrated Directory. To appear on the list, a piece must show at least one use of a single note, or a group of two notes, set off by silence in the texted voice.

The primary purpose of the list is to guide readers to specific examples of the small kind of hocket whose significance I have asserted in this article. A second purpose is to indicate something of the distribution of the device across the sources. Out of necessity, the search has been conducted on the basis of modern editions. However, this entails problems. Editorial policies with regard to notational strokes vary, as indeed do the meanings of strokes for scribes: they may signal rests, or merely serve as marks of division or alignment between metrical units and voices. Two sources of the 'same' motet may vary too, producing a hocket in one but not in the other. A particular hurdle is Tischler's choice, in The Earliest Motets, to present all witnesses of a piece and all contrafact texts in abbreviated parallel transcriptions. Moreover, although Tischler groups pieces by manuscript repertory, a motet is placed in a given manuscript's portion of the edition only if it does not share any material with a piece in an earlier source. Thus for the major collections of Ma, W2, MuA, R and N (which are only available in Tischler's Early Motets), it is impossible to give a comprehensive view of hockets in each repertory. It is likely that further hockets (or further sources of the listed hockets) will be found should more reliable editions be created, and I will welcome suggestions for further inclusions - and indeed, debate as to which hockets should be rejected. 
Sean Curran, 'Hockets Broken and Integrated in Early Mensural Theory and an Early Motet', Early Music History vol. 36 (2017); author's revised manuscript, accepted 4 May 2017.

Column 1: The source for the tenor, by its number in van der Werf, Integrated Directory. Unidentified tenors are marked 'UI'; tenors with French incipits, 'Fr'.; and tenors with no designation, 'ND'.

Column 2: The tenor incipit, standardized to the version given in van der Werf, Integrated Directory.

Column 3: The motet's number in van der Werf, Integrated Directory.

Column 4: The motet's incipit.

Column 5: Any contrafacta (that is, texts sharing the same melody), crossreferenced by their number in van der Werf, Integrated Directory. Most have an entry in the handlist in their own right; though where a contrafactum listed in column 5 does not have a hocket in its own source(s), it is not indexed separately.

The remaining columns report the location of the hocket in the five major editions that have been consulted. Arranged roughly in chronological order of their repertory, the editions are as follows:

Column 6: Tischler, ed., The Earliest Motets (containing the repertories of F, Ma, W2, MuA, N, and R, among others). Nos. 209-42 of this edition present pieces from $\mathrm{Cl}$, and were not consulted, because they are presented complete in the more accessible edition AndersonCl. A siglum in parentheses reports the earliest manuscript in which the hocket was detected.

Column 7: Anderson, ed., Motets of the Manuscript La Clayette (Cl). 
Sean Curran, 'Hockets Broken and Integrated in Early Mensural Theory and an Early Motet', Early Music History vol. 36 (2017); author's revised manuscript, accepted 4 May 2017.

Column 8: Tischler, ed., The Montpellier Codex (Mo).

Column 9: Anderson, ed., Compositions of the Bamberg Manuscript (Ba).

Column 10: Auda, ed., Les 'Motets Wallons' du manuscrit de Turin: Vari 42 $(\mathrm{Tu})$.

The motet's number in each edition is given in boldface; following the colon are the bar numbers where hockets are found. When more than three hockets are present, numbers are replaced with 'Ext' for 'extensive'; the reader should be able to find the hockets easily in those motets.

\section{[APPENDIX 2 TABLE GOES HERE]}




\section{CAPTIONS}

Appendix 1. Motet, Dame de valour (71) / Dame vostre doz regart (72) / MANERE (M5), transcribed from Mo, fols. $128^{\mathrm{v}}-130^{\mathrm{r}}$.

Appendix 2. A handlist of Ars Antiqua motet texts containing hockets.

Example 1. Hocket on In seculum, long-mode version, perfections 1-11, transcribed from Mo, fol. $111^{\mathrm{r}}$.

Example 2. The Anonymous of St. Emmeram's example of an 'incomplete' hocket, transcribed from Munich, Bayerische Staatsbibliothek, Clm 14523, fol. $153^{\mathrm{V}}$.

Example 3. Comparative analysis of the refrains vdB 238 and vdB 1233a*.

Example 4. Analytical transcription of the motetus Dame vostre doz regart (72), from Mo.

Example 5. Analytical transcription of the triplum Dame de valour (71), from Mo.

Example 6. Dame de valour (71) / Dame vostre doz regart (72) / Manere (M5), perfections $34-41$, transcribed from Mo, fols. $129^{\mathrm{v}}-130^{\mathrm{r}}$.

Table 1. Dame de valour (71) / Dame vostre doz regart (72) / MANERE (M5), network of witnesses (information from van der Werf, Integrated Directory, p. 20). 
Appendix 1. Score part 1.
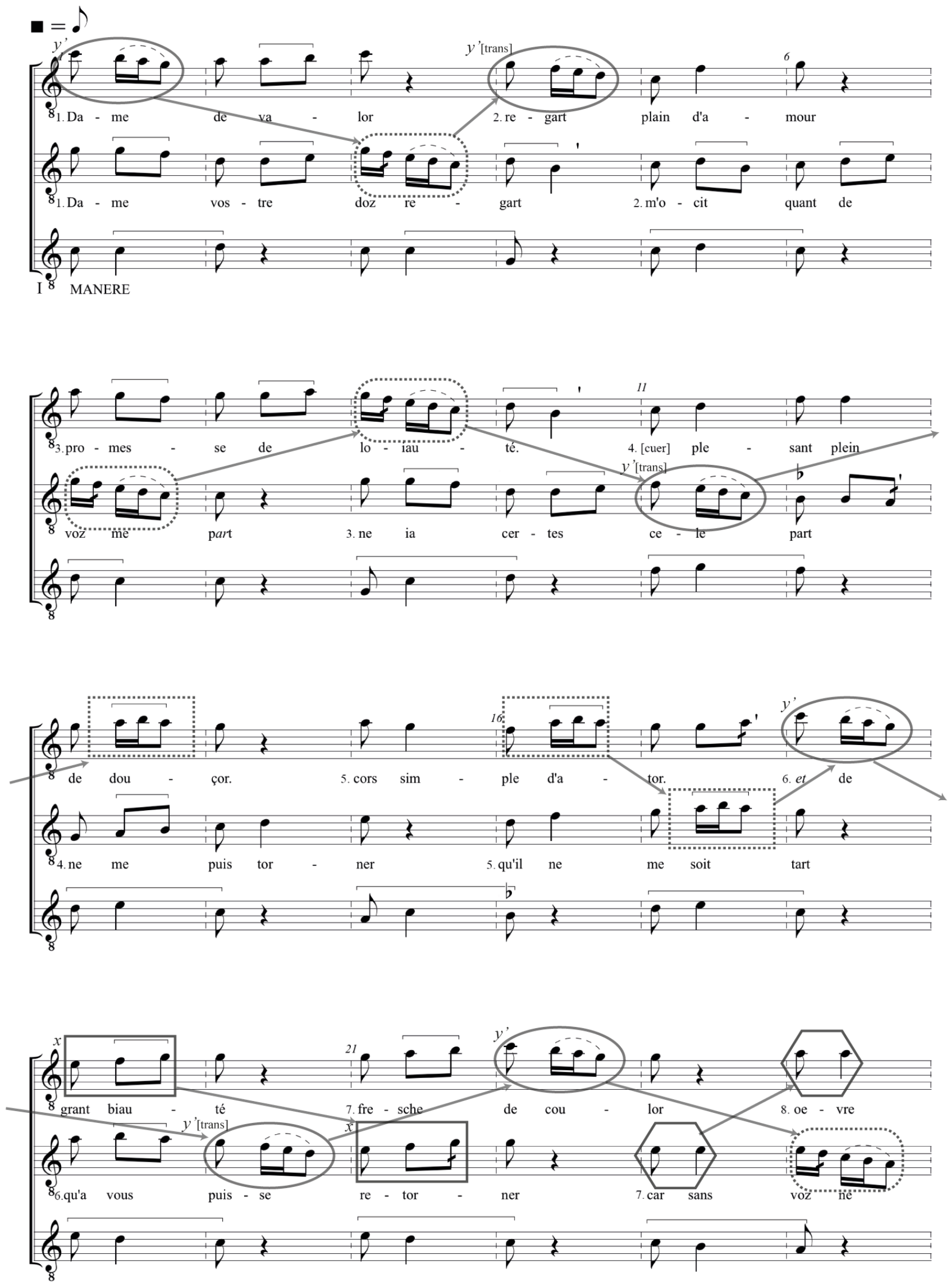
Appendix 1. Score part 2.
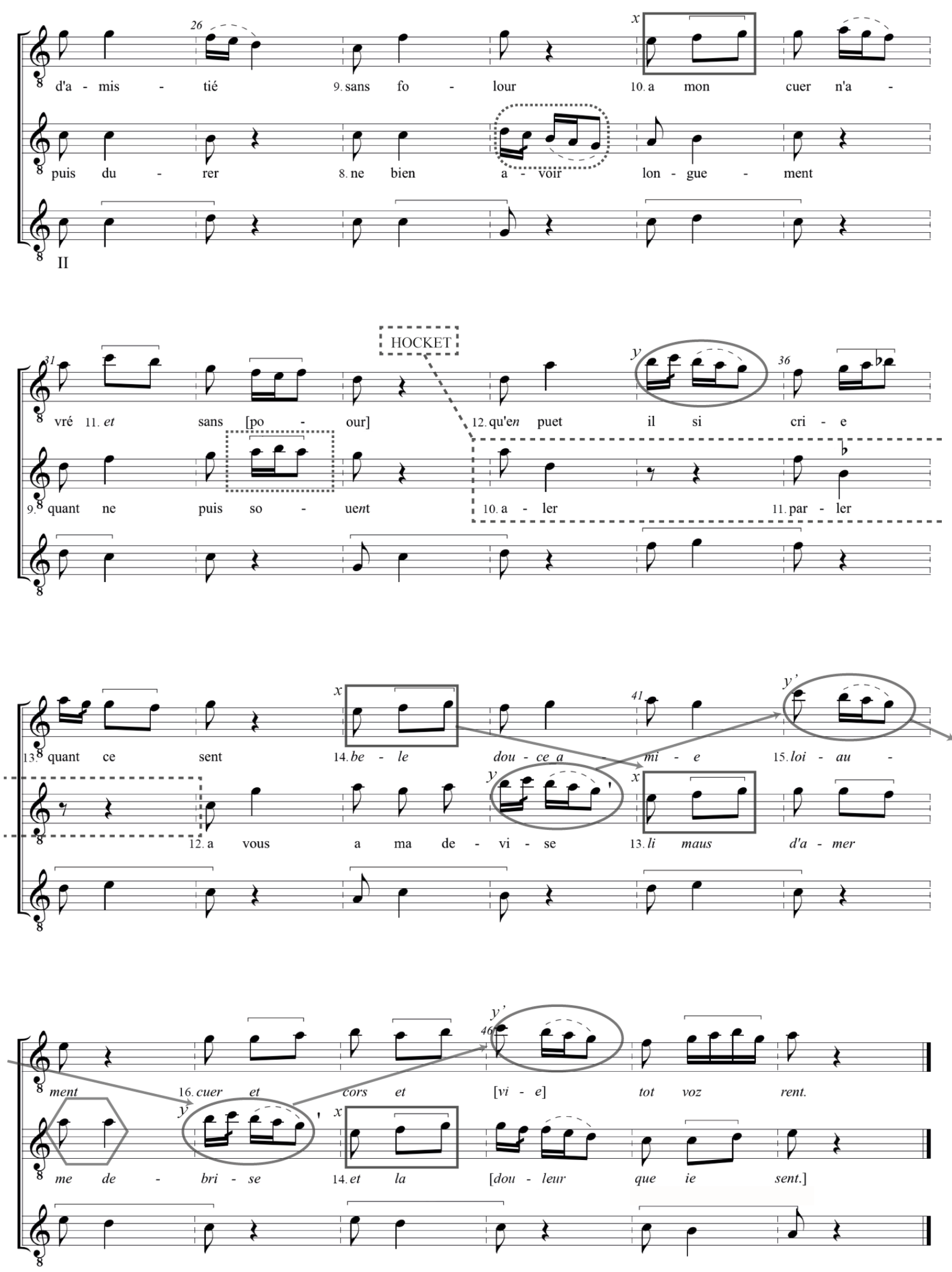


\begin{tabular}{|c|c|c|c|c|c|c|c|c|c|}
\hline Source & Tenor Incipit & vdW & Motet Incipit & $\begin{array}{l}\text { Contrafacta } \\
\text { vdW }\end{array}$ & TischlerEM & Anderson $\mathrm{Cl}$ & TischlerMo & Anderson $B a$ & AudaTu \\
\hline \multirow{4}{*}{ M1 } & \multirow{4}{*}{ OMNES } & \begin{tabular}{|l}
10 \\
\end{tabular} & $\begin{array}{l}\text { He amours morrai je pour } \\
\text { celi }\end{array}$ & & & & & 43: 18 & \\
\hline & & 17 & Tant mi plaist a vos penser & & & & & 91: 21 & \\
\hline & & 18 & Tout li cuers me rit de joie & & & & & 91: 21 & \\
\hline & & 36 & Salve virgo virginum salve & & & & 300 (Fa.7): Ext & & \\
\hline M3 & ADIUVA ME & 58 & Adesse festina monas & & \begin{tabular}{|l|}
$97(\mathrm{Ma}): 77,85$ \\
$268-269$ \\
\end{tabular} & & & & \\
\hline M4 & STANTEM & $68 \mathrm{a}$ & Quant li dous tens rasaige & & 256 (MuA): 20 & & & & \\
\hline \multirow[t]{2}{*}{ M5 } & \multirow[t]{2}{*}{ MANERE } & 72 & Dame vostre douz regart & 73 & \begin{tabular}{|l}
$142(\mathrm{~W} 2):$ \\
$17-19$ \\
\end{tabular} & 30: $17-19$ & 90 (Fa.5): 17-19 & & \\
\hline & & 73 & Jhesu Christi sedulus & 72 & \begin{tabular}{|l|}
142 (W2): \\
$17-19$ \\
\end{tabular} & & & & \\
\hline \multirow{2}{*}{ M12 } & {$[\mathrm{CONFI}] \mathrm{TE}[\mathrm{BOR}]$} & 111 & Traveillie d'un mau & 110 & & & \begin{tabular}{|l}
211 (Fa.6): 15-16, \\
$24-25$
\end{tabular} & & \\
\hline & ET CONFITEBOR & 114 & Je gart le bois & & & & 228 (Fa.6): 8 & & \\
\hline \multirow[t]{7}{*}{ M13 } & \multirow[t]{7}{*}{ IN SECULUM } & 141 & In serena facie & & 116 (W2): 34 & & & & \\
\hline & & 165 & Lonc tens ai mon cuer assis & & & & 218 (Fa.6): 16 & & \\
\hline & & 166 & La bele m'ocit Dieus & & & & 178 (Fa.6): 9, 35 & & \\
\hline & & 169 & Ne m'a pas oublie & & & & \begin{tabular}{|l|}
$207(\mathrm{Fa} .6): 33-36$, \\
$54-57,60$
\end{tabular} & & \\
\hline & & 176 & Dieus de chanter maintenant & & & & $87(\mathrm{Fa} .5): 22$ & & \\
\hline & & 186 & La biaute ma dame & & & 46: $28-29$ & $134($ Fa.5): 32-33 & & \\
\hline & & 190 & Se gries m'est au cors & & & & $162(\mathrm{Fa} .5): 21$ & & \\
\hline
\end{tabular}


Appendix 2. Table. p. 2

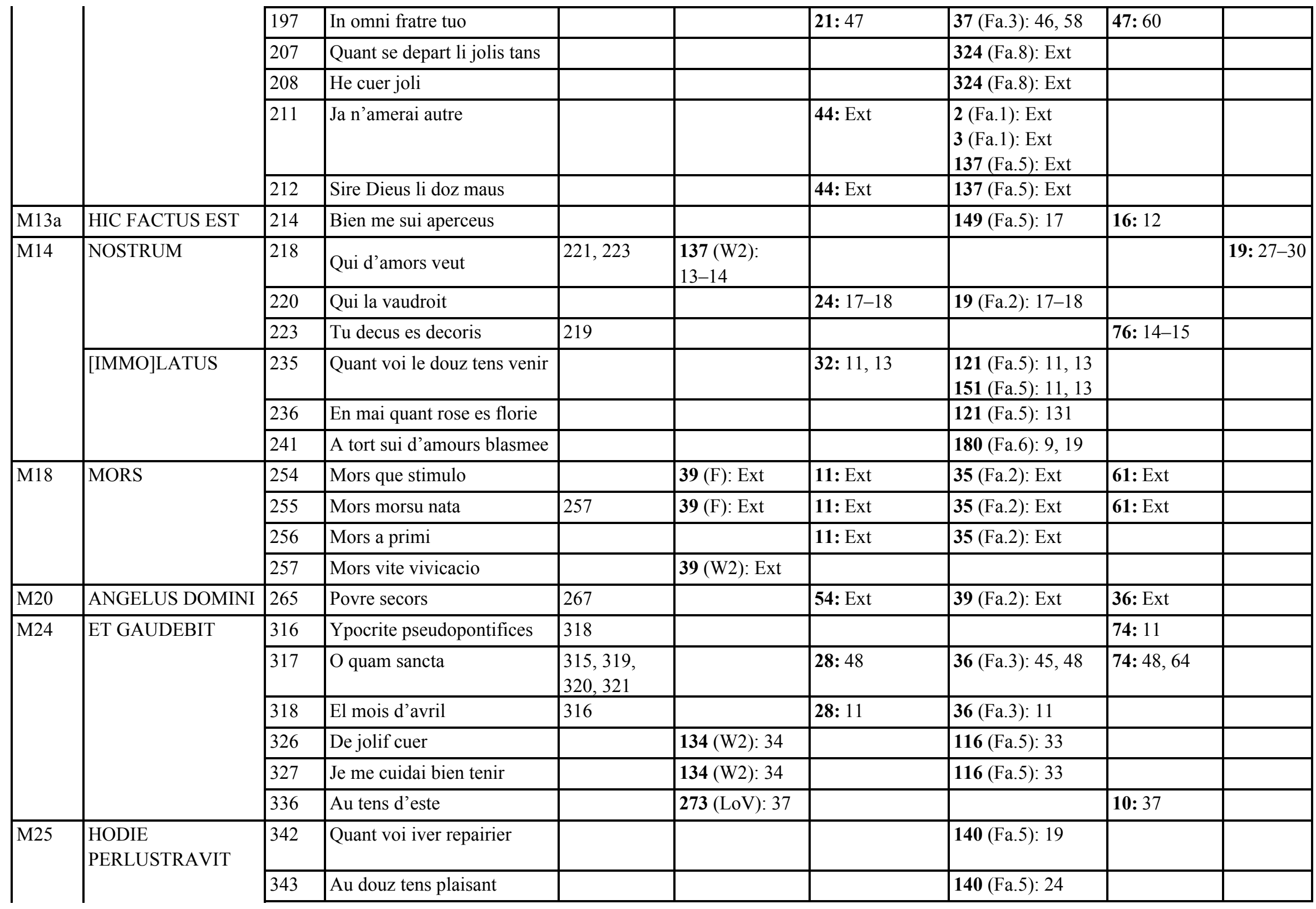




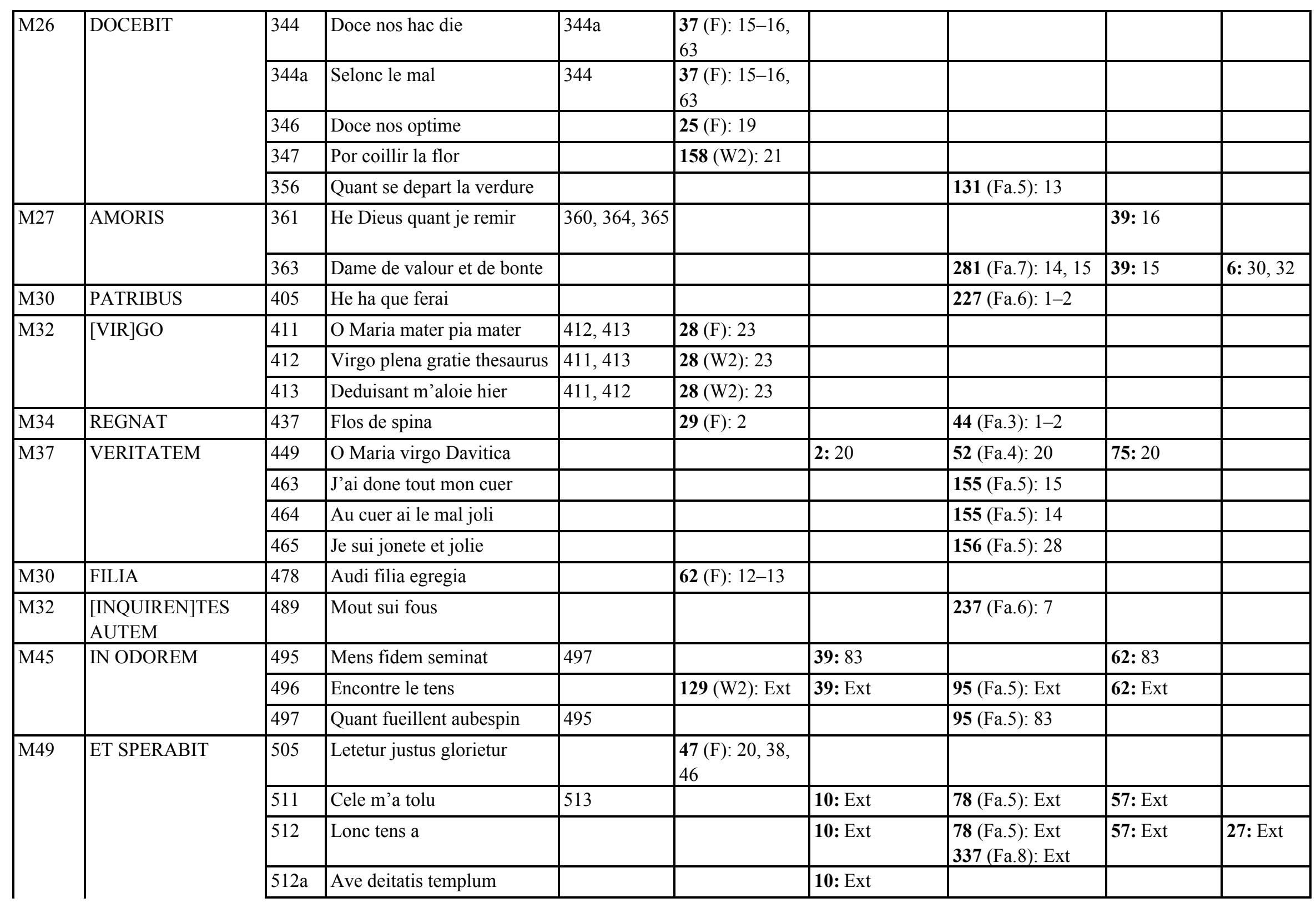




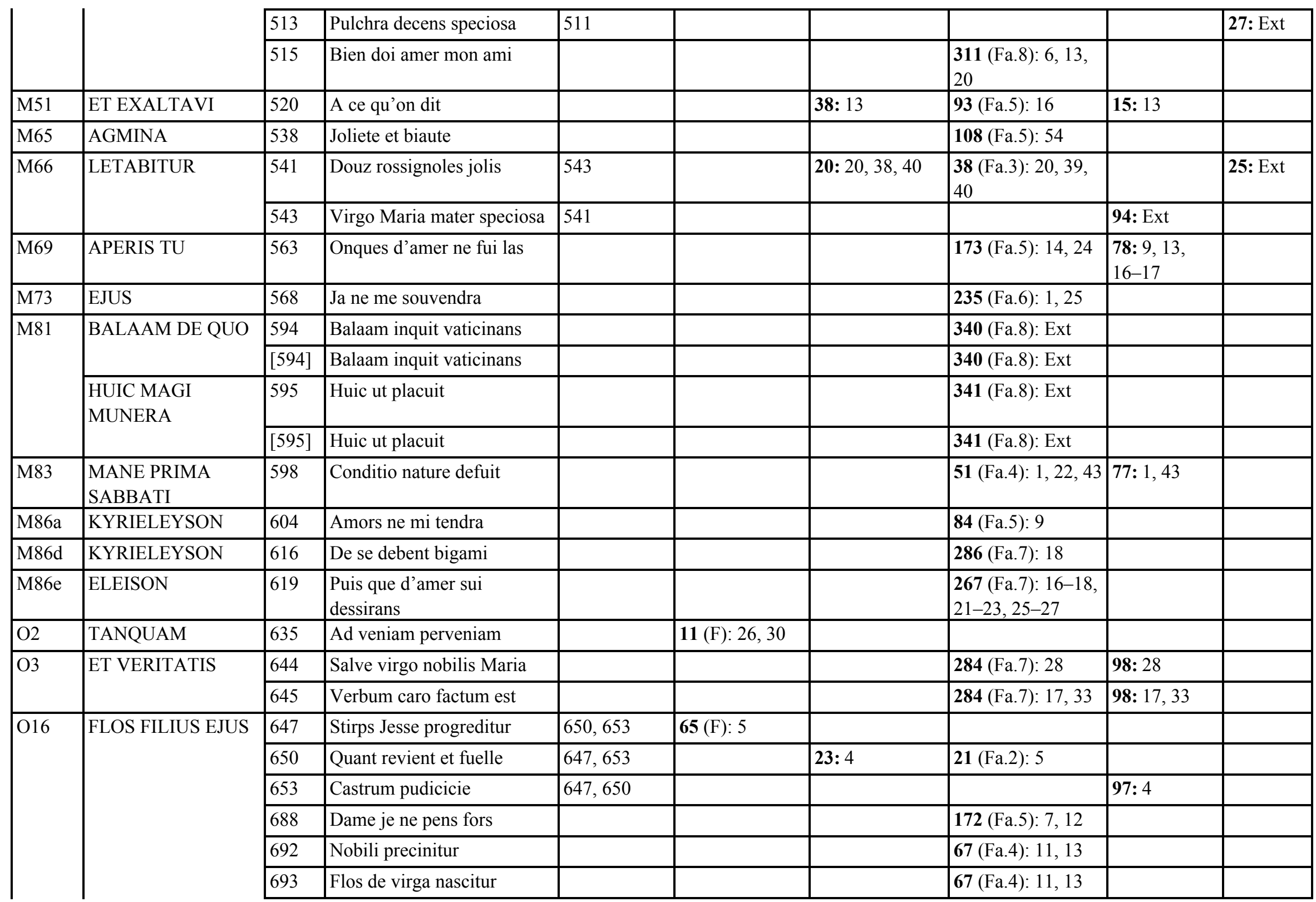


Appendix 2. Table p. 5.

\begin{tabular}{|c|c|c|c|c|c|c|c|c|c|}
\hline \multirow[t]{4}{*}{ O19 } & \multirow[t]{4}{*}{ SOLEM JUSTITIE } & 699 & Jam nubes dissolvitur & & & & 275 (Fa.7): Ext & & 5: Ext \\
\hline & & 700 & Jam novum sidus oritur & & & & 275 (Fa.7): Ext & & 5: Ext \\
\hline & & 703 & Je cuidoie bien metre jus & & & & 332 (Fa.8): Ext & & \\
\hline & & 704 & Se j'ai folement ame & & & & 332 (Fa.8): Ext & & \\
\hline \multirow[t]{5}{*}{$\mathrm{O} 46$} & \multirow[t]{5}{*}{ APTATUR } & 716 & $\begin{array}{l}\text { He Marotele alons au bois } \\
\text { jouer }\end{array}$ & 718 & & & \begin{tabular}{|l|}
$\mathbf{7 5}$ (Fa.5): 1 \\
147 (Fa.5): 1 \\
\end{tabular} & & 34: 1 \\
\hline & & 718 & He Mere Diu & 716 & & & 146 (Fa.5): 1 & & \\
\hline & & 725 & Entre Adam et Haniket & & & & & 24: 29 & \\
\hline & & 733 & Marie preconio & & & & & 59: 21,23 & \\
\hline & & 736 & Nus ne m'i pourroit & & & & & 71: 1 & \\
\hline \multirow[t]{4}{*}{$\overline{B D-V I}$} & \multirow[t]{4}{*}{ DOMINO } & 762 & Alpha bovi et leoni & $763,764,765$ & \begin{tabular}{|l}
$57(\mathrm{~F}): 23-29$, \\
$35-39$ \\
\end{tabular} & & & & \\
\hline & & 763 & Larga manu seminatum & $762,764,765$ & \begin{tabular}{|l|}
$\mathbf{5 7}(\mathrm{W} 2):$ \\
$23-29,35-39$ \\
\end{tabular} & & & & \\
\hline & & 764 & Hier matin a l'enjournee & $762,763,765$ & $\begin{array}{l}57(\mathrm{~W} 2): \\
23-29,35-39 \\
\end{array}$ & & & & \\
\hline & & 765 & Hier matin a l'ajournee & $762,763,764$ & 57: Chanson & & & & \\
\hline $\mathrm{O} 51$ & \begin{tabular}{|l|} 
AVE MARIS \\
STELLA \\
\end{tabular} & $778 \mathrm{~b}$ & Ave Maria gracia plena & & & 36: 9 & & & \\
\hline $\mathrm{O} 52$ & $\begin{array}{l}\text { SECULORUM } \\
\text { AMEN }\end{array}$ & 779 & Pour escouter le chant & & & & 112 (Fa.5): 1 & & \\
\hline $\mathrm{O} 53 \mathrm{c}$ & NEUMA & 788 & Pleust Diu qu'ele seust & & & & $117(\mathrm{Fa} .5): 22$ & & \\
\hline \multirow[t]{3}{*}{ UI } & \multirow[t]{3}{*}{ DOMINO II } & 807 & Par une matinee & 809,810 & & & & & \\
\hline & & 809 & O Maria mater pia spes & 807,810 & 217 (PsAr): 11 & & & & \\
\hline & & 810 & Virginis preconia & 807,809 & & & & 58: 11 & \\
\hline UI & HODIE & 828 & Dieus, je ne m'en partirai & & & & 79 (Fa.5): 1 & & \\
\hline$\overline{\mathrm{UI}}$ & OMNES & 829 & A vos douce debonaire & & & & 195 (Fa.6): 27 & & \\
\hline$\overline{\mathrm{UI}}$ & NOTUM & 845 & $\begin{array}{l}\text { Amours qui vient par } \\
\text { message }\end{array}$ & & & & & 93: 24 & \\
\hline \multirow[t]{2}{*}{ UI } & \multirow[t]{2}{*}{ PORTAS } & 853 & Porta preminentie & & & & 315 (Fa.8): 1 & & \\
\hline & & 854 & Porta penitentie & & & & 315 (Fa.8): 1, 11 & & \\
\hline
\end{tabular}




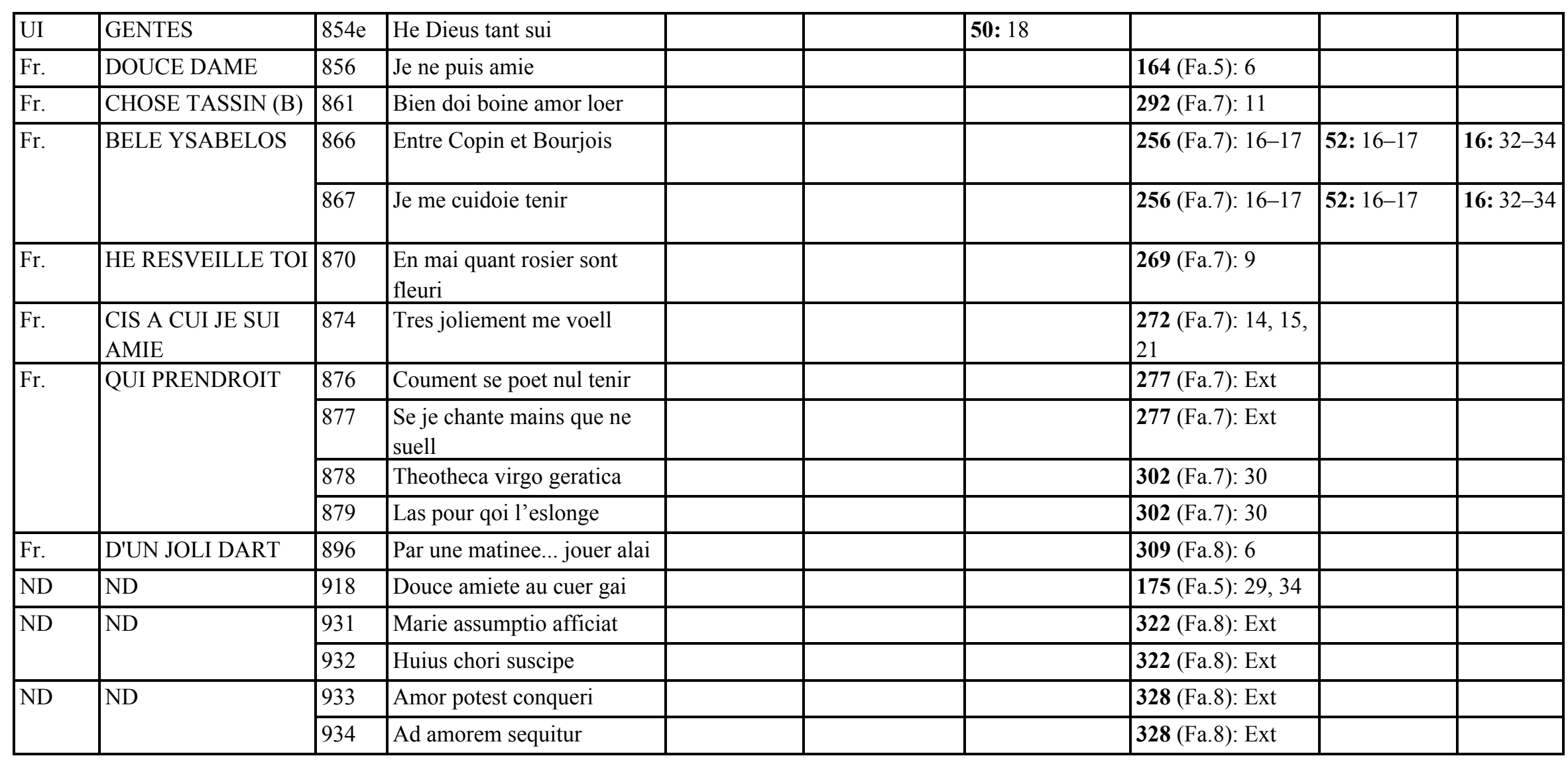


Example 1.

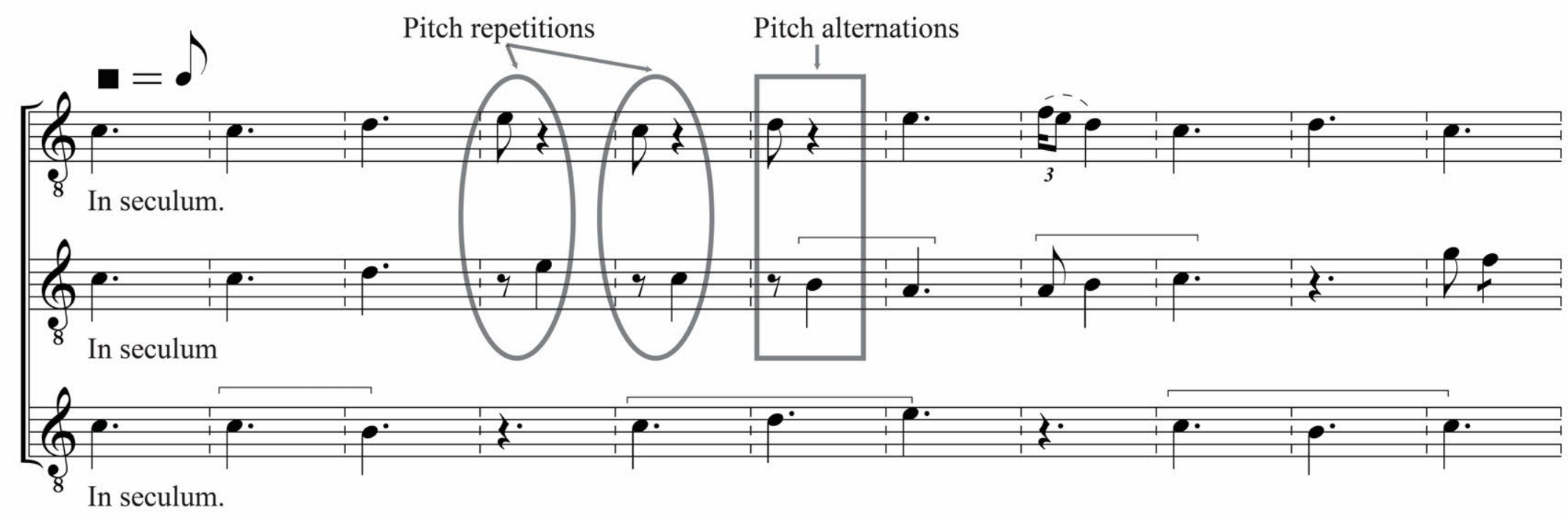


Example 2.

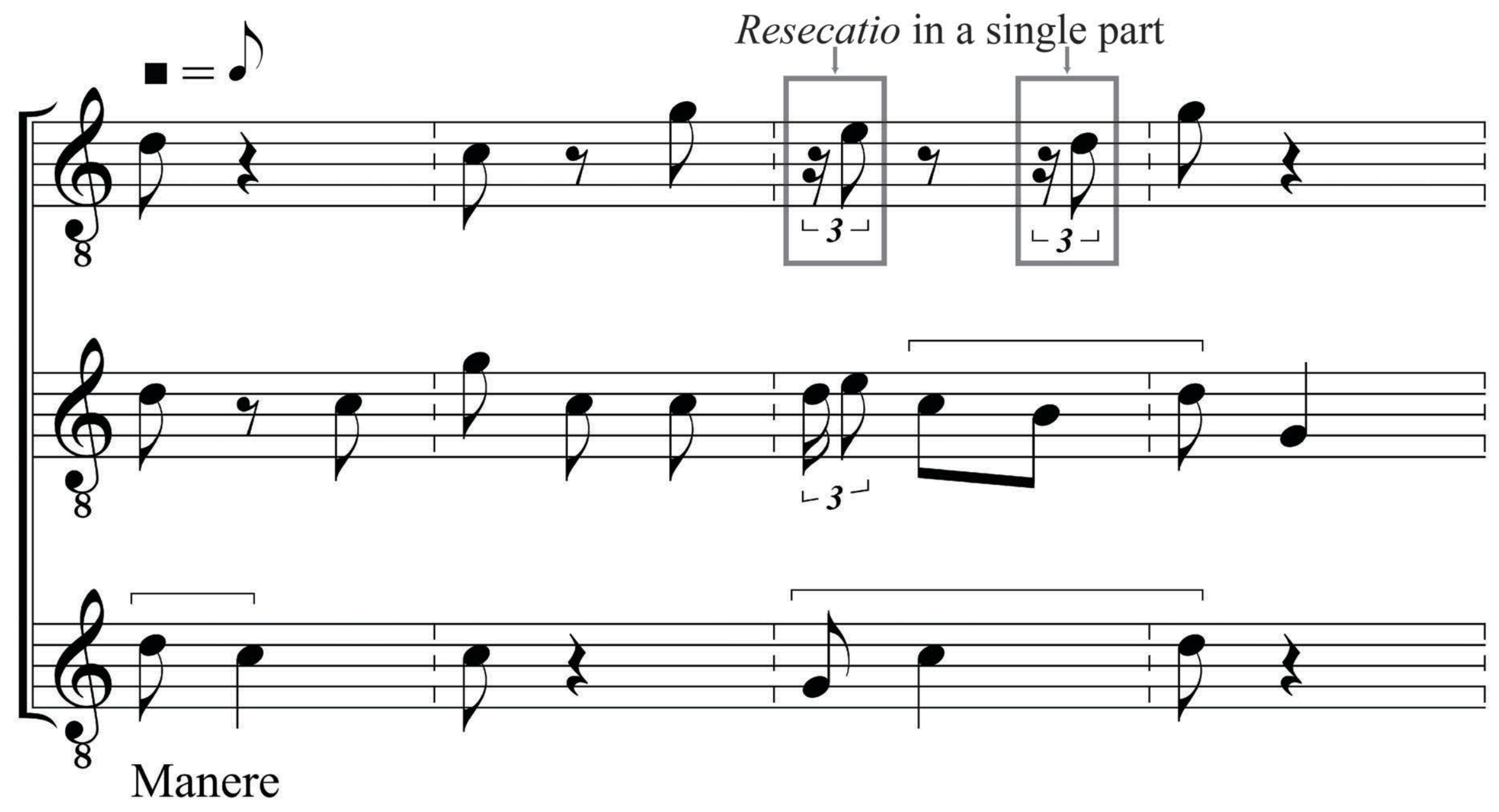




\section{Table 1.}

\section{Case-study version:}

Three-part French motet:

Triplum: Dame de valour (71)

Motetus: Dame vostre douz regart (72)

Tenor: MANERE (M5)

Sources:

W2: fol. $209^{\mathrm{r}}-209^{\mathrm{v}}$ [= 'W2(a)' in my references]

Mo: fol. $128^{\mathrm{v}}-130^{\mathrm{r}}$

Cl: fol. $382^{\mathrm{r}}$

\section{Other versions:}

Two-part French motet:

Motetus: Dame vostre douz regart (72)

Tenor: MANERE (M5)

Source:

MuA: fol. $8^{\mathrm{r}}$

Two-part Latin motet (contrafact):

Motetus: Jhesu Christi sedulus Johanne discipulus (73)

Tenor: MANERE (M5)

Source:

W2: fol. $182^{\mathrm{v}}$ [= 'W2(b)' in my references] 
Example 3.

Triplum refrain: vdB 238

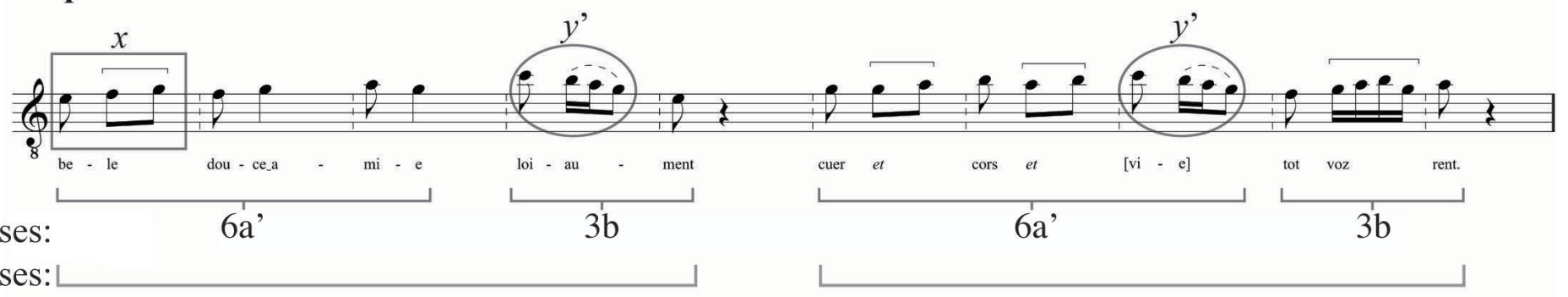

Motetus refrain: vdB 1233a*

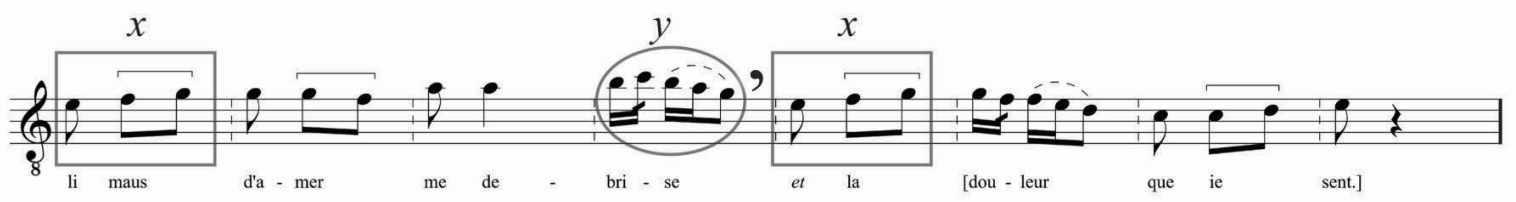

2 verses:

$8 \mathrm{a}$

$7 \mathrm{~b}$

2 phrases: 
Example 4.

Phrase
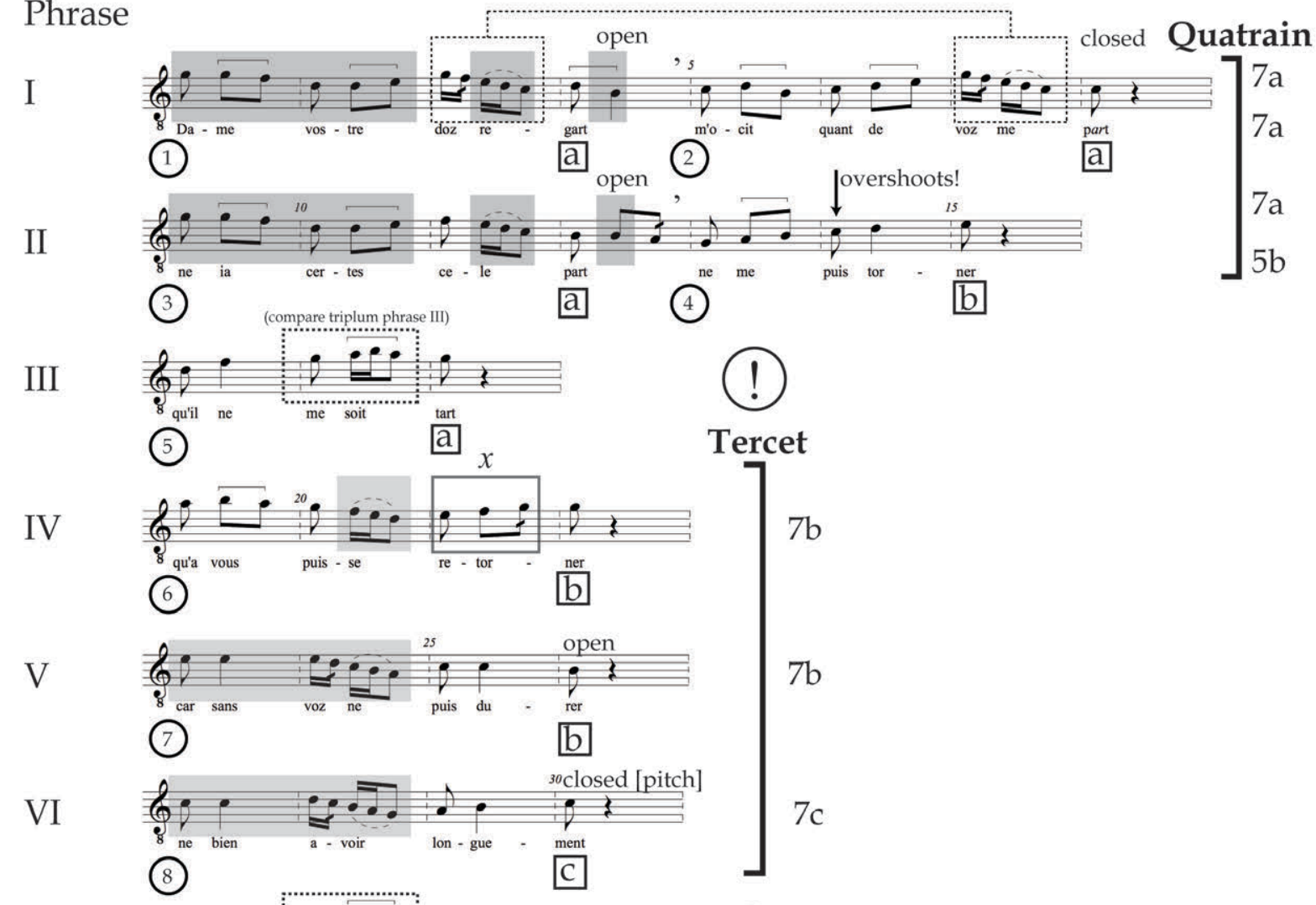

VII

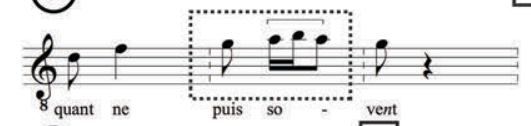

(1)

(9)

V

VIII

(!)

(11) $b$

(!)

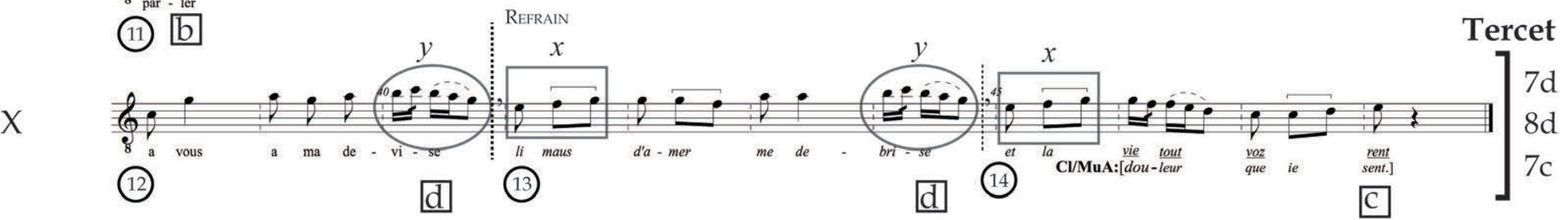


I

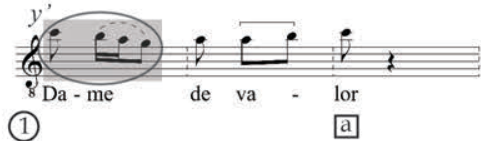

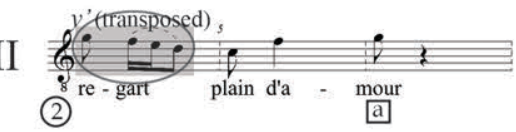

III

IV

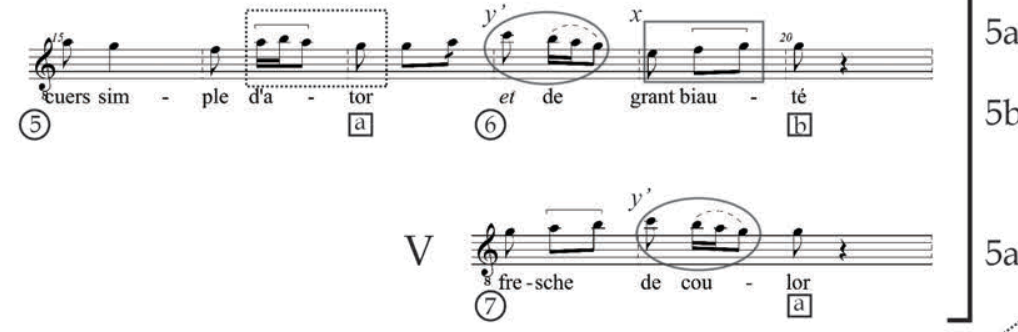

Example 5.

Segment 3

Dovetail of
descriptive modes $\left\{\begin{array}{lll}\text { Musical description of the refrain begins } \\ \text { Literary description of the Lady ends }\end{array}\right.$


Example 6.

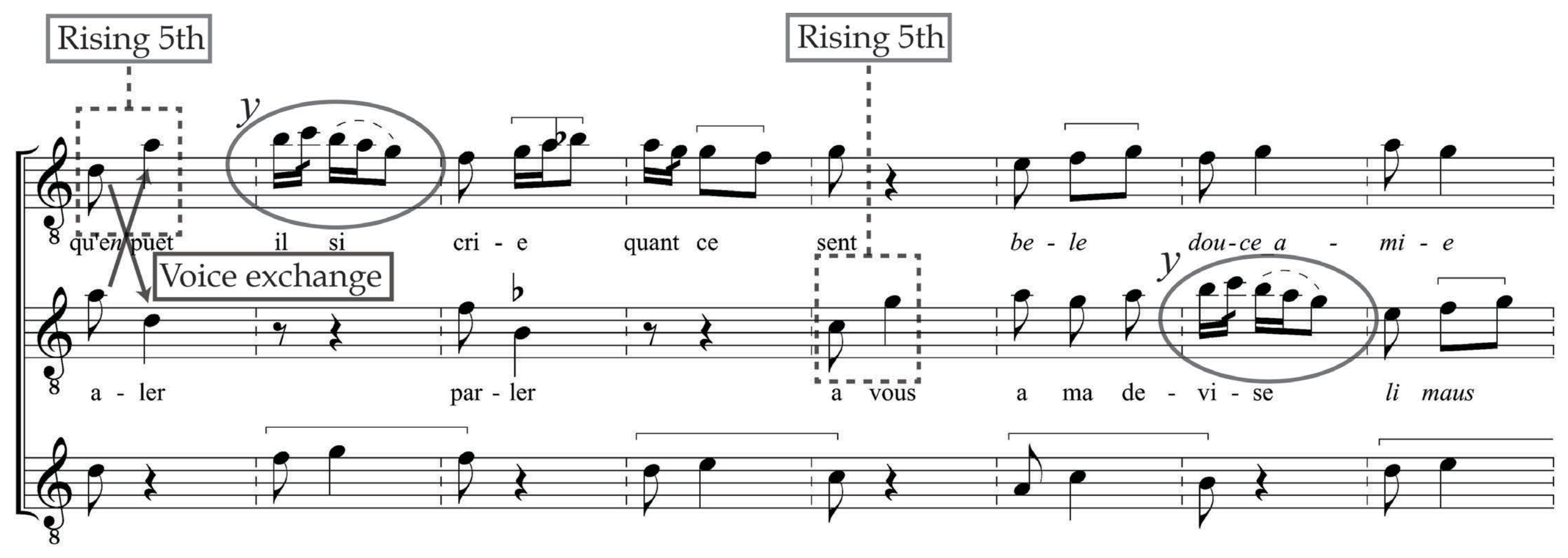

